\title{
The Hydrothermal System of Long Valley Caldera, California
}

By M. L. Sorey, R. E. Lewis, and F. H. Olmsted

GEOHYDROLOGY OF GEOTHERM A L SYSTEMS

GEOLOGICAL SURVEY PROFESSIONAL PAPER 1044-A 


\section{DISCLAIMER}

This report was prepared as an account of work sponsored by an agency of the United States Government. Neither the United States Government nor any agency Thereof, nor any of their employees, makes any warranty, express or implied, or assumes any legal liability or responsibility for the accuracy, completeness, or usefulness of any information, apparatus, product, or process disclosed, or represents that its use would not infringe privately owned rights. Reference herein to any specific commercial product, process, or service by trade name, trademark, manufacturer, or otherwise does not necessarily constitute or imply its endorsement, recommendation, or favoring by the United States Government or any agency thereof. The views and opinions of authors expressed herein do not necessarily state or reflect those of the United States Government or any agency thereof. 


\section{DISCLAIMER}

Portions of this document may be illegible in electronic image products. Images are produced from the best available original document. 


\section{UNITED STATES DEPARTMENT OF THE INTERIOR \\ CECIL D. ANDRUS, Secretary}

\section{GEOLOGICAL SURVEY}

H. William Menard, Director

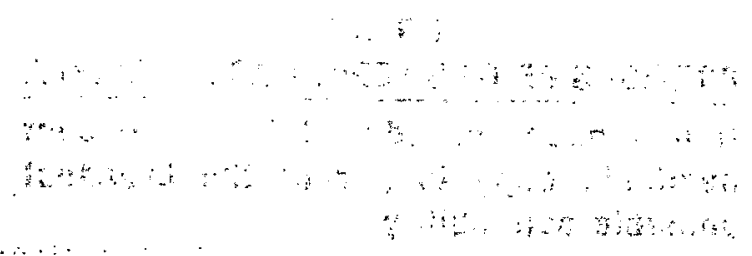

For sale by the Superintendent of Documents, U.S. Government Printing Office Washington, D.C. 20402

Stock Number 024-001-03107-8 


\section{CONTENTS}

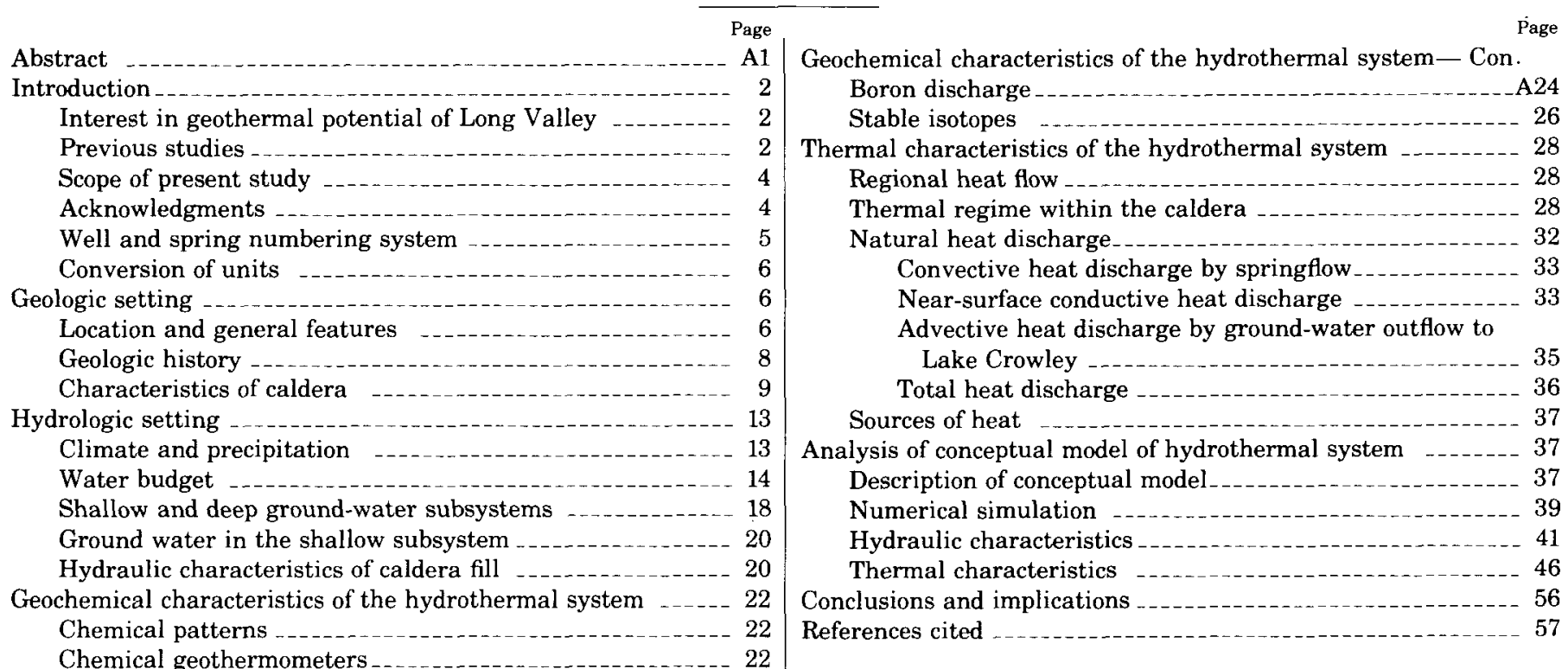

\section{ILLUSTRATIONS}

Plate

Figure
1. Generalized geologic map of Long Valley area showing location of wells, springs, and hydrologic of meterologic data stations In Pocket

1. Diagram of system for numbering wells and springs

2. Index map showing location of Long Valley area

3. Map showing thickness of fill in Long Valley caldera

4. Map showing thickness of fill above densely welded part of Bishop Tuff in Long Valley caldera

5. Map showing average annual precipitation in the Long Valley basin

6. Annual precipitation at Lake Mary Store and Long Valley Dam

7. Relation between precipitation and altitude at stations on the east slope of the central Sierra Nevada

8. Map showing tributary drainage areas and streamflow-measuring stations in the Long Valley basin

9. Relation between precipitation and runoff for streams within Long Valley drainage basin

10. Map of Long Valley caldera showing configuration of the water table, spring 1973

11. Relations between concentrations of deuterium and ${ }^{18} \mathrm{O}$ in Long Valley waters

12. Map of Long Valley caldera showing location of sampling points for deuterium and ${ }^{18} \mathrm{O}$ analyses

13. Temperature profiles from core holes and shallow holes in Long Valley caldera

14. Map of Long Valley caldera showing temperature at a depth of $15 \mathrm{~m}, 1973-74$

15. Map of Long Valley caldera showing near-surface conductive heat flow, 1973-74

16. Relation between temperatures at depths of $15 \mathrm{~m}$ and $10 \mathrm{~m}$ in Long Valley caldera, October 1974

17. Map showing elements used in estimate of thermal ground-water flow into Lake Crowley

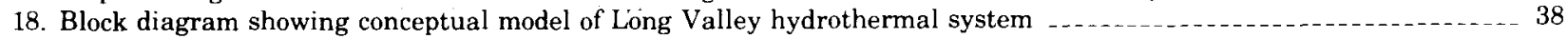

19. Sketch map of Long Valley caldera showing nodal configuration for numerical simulation of hydrothermal system with uniform reservoir permeability distribution (case A)

20. Sketch map of Long Valley caldera showing nodal configuration for numerical simulation of hydrothermal system with fault-zone reservoir permeability distribution (case B)

21. Sketch map of Long Valley caldera showing nodal configuration for numerical simulation of hydrothermal system with low-permeability-block reservoir permeability distribution (case C)

22. Sketch map of Long Valley caldera showing equivalent hydraulic head in reservoir from 1 to $2 \mathrm{~km}$ deep from case A with uniform reservoir permeability of 30 millidarcys, hot-spring discharge of $250 \mathrm{~kg} / \mathrm{s}$ in Hot Creek gorge, southeast-rim outflow of $110 \mathrm{~kg} / \mathrm{s}$, and simulation period of 35,000 years $\ldots$ 
Figure 23. Sketch map of.Long Valley caldera showing equivalent hydraulic head in reservoir from 1 to $2 \mathrm{~km}$ deep from case $\mathrm{C}$ with low-permeability-block reservoir west of Casa Diablo Hot Springs, permeability of 45 millidarcys in remainder of western three-fifths of caldera, and permeability of 30 millidarcys in eastern two-fifths of caldera

24. Diagrammatic east-west cross section of Long Valley caldera showing steady-state, conduction-only isotherms from
model simulations without fluid flow and used as initial conditions in simulations of flow in the hydrothermal

24. Diagrammatic east-west cross section of Long Valley caldera showing steady-state, conduction-only isotherms from
model simulations without fluid flow and used as initial conditions in simulations of flow in the hydrothermal system

25. Map of Long Valley caldera showing steady-state conductive heat flow above reservoir (from model simulation) without fluid flow

26. Diagrammatic east-west cross section of Long Valley caldera showing isotherms from model simulation (case
A--uniform reservoir permeability distribution) after 35,000 years with a discharge of $250 \mathrm{~kg} / \mathrm{s}$ in Hot Creek gorge,

26. Diagrammatic east-west cross section of Long Valley caldera showing isotherms from model simulation (case
A-uniform reservoir permeability distribution) after 35,000 years with a discharge of $250 \mathrm{~kg} / \mathrm{s}$ in Hot Creek gorge, southeast-rim outflow of $110 \mathrm{~kg} / \mathrm{s}$, and reservoir depth of 1 to $2 \mathrm{~km}$ $p$ of Long Valley caldera showing distribution of average reservoir temperature from model simulation (case

27. Map of Long Valley caldera showing distribution of average reservoir temperature from model simulation (case
A-uniform reservoir permeability distribution) after 35,000 years with a discharge of $250 \mathrm{~kg} / \mathrm{s}$ in Hot Creek gorge,
southeast-rim outflow of $110 \mathrm{~kg} / \mathrm{s}$, and reservoir depth of 1 to $2 \mathrm{~km}$
28. Diagrammatic east-west cross section of Long Valley caldera showing isotherms from model simulation (case C-low
permeability-block reservoir west of Casa Diablo) after 35,000 years with discharge of $250 \mathrm{~kg} / \mathrm{s} \mathrm{in} \mathrm{Hot} \mathrm{Creek} \mathrm{gorge,}$
southeast-rim outflow of $110 \mathrm{~kg} / \mathrm{s}$, and reservoir depth of 1 to $2 \mathrm{~km}$

27. Map of Long Valley caldera showing distribution of average reservoir temperature from model simulation (case
A-uniform reservoir permeability distribution) after 35,000 years with a discharge of $250 \mathrm{~kg} / \mathrm{s}$ in Hot Creek gorge,
southeast-rim outflow of $110 \mathrm{~kg} / \mathrm{s}$, and reservoir depth of 1 to $2 \mathrm{~km}$ -
28. Diagrammatic east-west cross section of Long Valley caldera showing isotherms from model simulation (case C-low
permeability-block reservoir west of Casa Diablo) after 35,000 years with discharge of $250 \mathrm{~kg} / \mathrm{s}$ in Hot Creek gorge,
southeast-rim outflow of $110 \mathrm{~kg} / \mathrm{s}$, and reservoir depth of 1 to $2 \mathrm{~km}$

27. Map of Long Valley caldera showing distribution of average reservoir temperature from model simulation (case
A-uniform reservoir permeability distribution) after 35,000 years with a discharge of $250 \mathrm{~kg} / \mathrm{s}$ in Hot Creek gorge,
southeast-rim outflow of $110 \mathrm{~kg} / \mathrm{s}$, and reservoir depth of 1 to $2 \mathrm{~km}$
28. Diagrammatic east-west cross section of Long Valley caldera showing isotherms from model simulation (case C-low
permeability-block reservoir west of Casa Diablo) after 35,000 years with discharge of $250 \mathrm{~kg} / \mathrm{s} \mathrm{in} \mathrm{Hot} \mathrm{Creek} \mathrm{gorge,}$
southeast-rim outflow of $110 \mathrm{~kg} / \mathrm{s}$, and reservoir depth of 1 to $2 \mathrm{~km}$

27. Map of Long Valley caldera showing distribution of average reservoir temperature from model simulation (case
A-uniform reservoir permeability distribution) after 35,000 years with a discharge of $250 \mathrm{~kg} / \mathrm{s}$ in Hot Creek gorge,
southeast-rim outflow of $110 \mathrm{~kg} / \mathrm{s}$, and reservoir depth of 1 to $2 \mathrm{~km}$
28. Diagrammatic east-west cross section of Long Valley caldera showing isotherms from model simulation (case C-low
permeability-block reservoir west of Casa Diablo) after 35,000 years with discharge of $250 \mathrm{~kg} / \mathrm{s}$ in Hot Creek gorge,
southeast-rim outflow of $110 \mathrm{~kg} / \mathrm{s}$, and reservoir depth of 1 to $2 \mathrm{~km}$

29. Map of Long Valley caldera showing distribution of average reservoir temperature from model simulation (case $\mathrm{C}-$ low permeability-block reservoir west of Casa Diablo) after 35,000 years with discharge of $250 \mathrm{~kg} / \mathrm{s}$ in Hot Creek gorge, southeast-rim outflow of $110 \mathrm{~kg} / \mathrm{s}$, and reservoir depth of 1 to $2 \mathrm{~km}$

30. Map of Long Valley caldera showing results from model simulations (case A-uniform reservoir-permeability distribution) in terms of conductive heat flow above a depth of $0.5 \mathrm{~km}$ after 35,000 years with discharge of $250 \mathrm{~kg} / \mathrm{s}$ in $\mathrm{Hot}$ Creek gorge, southeast-rim outflow of $110 \mathrm{~kg} / \mathrm{s}$, and reservoir depth of 1 to $2 \mathrm{~km}$ agrammatic east-west cross section of Long Valley caldera showing isotherms from model simulation (case A-uniform reservoir-permeability distribution) after 350,000 years with hot-spring discharge of $250 \mathrm{~kg} / \mathrm{s}$, southeast-rim outflow of $110 \mathrm{~kg} / \mathrm{s}$, and reservoir depth of 1 to $2 \mathrm{~km}$

32. Transient response since initiation of springflow of average reservoir temperature below Hot Creek gorge for two reservoir depths, from model simulation (case A-uniform reservoir-permeability distribution) with discharge of $300 \mathrm{~kg} / \mathrm{s}$ in Hot Creek gorge and southeast rim outflow of $110 \mathrm{~kg} / \mathrm{s}$

33. Diagrammatic east-west cross sections of Long Valley caldera showing isotherms and convection patterns from model simulations (case A-uniform reservoir-permeability distribution) after 35,000 years (part A) and 350,000 years (part B), with cellular convection in reservoir at 1-3-km depth, hot-spring discharge of $250 \mathrm{~kg} / \mathrm{s}$, and southeast-rim outflow of $110 \mathrm{~kg} / \mathrm{s}$.

34. Effect of nodal spacing in vertical direction on average reservoir temperature under Hot Creek gorge after 35,000 years and 350,000 years of fluid flow in 2-dimensional, vertical-cross-section model simulation of Long Valley hydrothermal system. Cross section aligned east-west from Hot Creek gorge to west rim; mass flux through reservoir between $1-2-\mathrm{km}$ depth set at 1/10th of flux in 3-dimensional model, or $25 \mathrm{~kg} / \mathrm{s}$

\section{TABLES}

TABLE

Page

2. Calculations of volume and average thickness of fill in Long Valley caldera

3. Water budget for the Long Valley drainage basin for water years 196474

4. Estimated runoff from ungaged areas in the Long Valley drainage basin

5. Laboratory data for selected cores from test holes in Long Valley caldera .

6. Selected chemical constituents, termperatures, and isotopic compositions for thermal and nonthermal waters from Long Valley _._.

7. Temperatures of reservoirs feeding hot springs in Long Valley estimated by chemical geothermometers ........... 23

8. Measured concentrations of chemical elements in Long Valley rocks and total amounts discharged from Long Valley into Searles Lake ..._.

9. Size of leached reservoir required to supply total discharges of $\mathrm{B}$ and $\mathrm{Cl}$ for various changes in $\mathrm{B}$ and $\mathrm{Cl}$ concentrations in the reservoir rock

10. Generalized lithologic descriptions and thermal conductivity data from cores and cuttings at test-hole sites in Long Valley caldera -

11. Previous estimates of convective heat discharge from Long Valley caldera

12. Convective heat discharge by springflow from Long Valley caldera

13. Near-surface conductive heat discharge from Long Valley caldera

14. Hydraulic and thermal properties for Long Valley hydrothermal model

15. Intrinsic-permeability data from Long Valley model and other studies _

16. Conductive and convective heat discharge for each case of reservoir-permeability distribution after 35,000 years of fluid flow at $250 \mathrm{~kg} / \mathrm{s}$ in reservoir at $1-2-\mathrm{km}$ depth

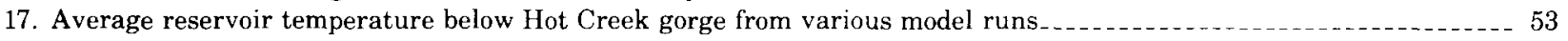


GEOHYDROLOGY OF GEOTHERMAL SYSTEMS

\title{
THE HYDROTHERMAL SYSTEM OF LONG VALLEY CALDERA, CALIFORNIA
}

\author{
By M. L. Sorey, R. E. Lewis, and F. H. Olmsted
}

\section{ABSTRACT}

Long Valley caldera, an elliptical depression covering $450 \mathrm{~km}^{2}$ on the eastern front of the Sierra Nevada in east-central California, contains a hot-water convection system with numerous hot springs and measured and estimated aquifer temperatures at depths of $180^{\circ} \mathrm{C}$ to $280^{\circ} \mathrm{C}$. In this study we have synthesized the results of previous geologic, geophysical, geochemical, and hydrologic investigations of the Long Valley area to develop a generalized conceptual and mathematical model which describes the gross features of heat and fluid flow in the hydrothermal system.

Cenozoic volcanism in the Long Valley region began about $3.2 \mathrm{~m} . \mathrm{y}$. (million years) ago and has continued intermittently until the present time. The major event that resulted in the formation of the Long Valley caldera took place about $0.7 \mathrm{~m}$.y. ago with the eruption of 600 $\mathrm{km}^{3}$ or more of Bishop Tuff of Pleistocene age, a rhyolitic ash flow, and subsequent collapse of the roof of the magma chamber along one or more steeply inclined ring fractures. Subsequent intracaldera volcanism and uplift of the west-central part of the caldera floor formed a subcircular resurgent dome about $10 \mathrm{~km}$ in diameter surrounded by a moat containing rhyolitic, rhyodacitic, and basaltic rocks ranging in age from 0.06 to $0.05 \mathrm{~m} . \mathrm{y}$.

On the basis of gravity and seismic studies, we estimate an average thickness of fill of $2.4 \mathrm{~km}$ above the precaldera granitic and metamorphic basement rocks. A continuous layer of densely welded Bishop Tuff overlies the basement rocks, with an average thickness of $1.4 \mathrm{~km}$; the fill above the welded Bishop Tuff consists of intercalated volcanic flows and tuffs and fluvial and lacustrine deposits. Assuming the average grain density of the fill is between 2.45 and $2.65 \mathrm{~g} / \mathrm{cm}^{3}$, we calculate the average bulk porosity of the total fill as from 0.11 to 0.21 . Comparison of published values of porosity of the welded Bishop Tuff exposed southeast of the caldera with calculated values indicates average bulk porosity for the welded tuff (including fracture porosity) from 0.05 to 0.10 . Because of its continuity and depth and the likelihood of significant fracture permeability in the more competent rocks such as the welded tuff, our model of the hydrothermal system assumes that the Bishop Tuff provides the principal hot-water reservoir. However, because very little direct information exists from drill holes below $300 \mathrm{~m}$, this assumption must be considered tentative.

Long Valley caldera is drained by the Owens River and several tributaries which flow into Lake Crowley in the southeast end of the caldera. Streamflow and springflow measurements for water years 1964-74 indicate a total inflow to Lake Crowley of about $10,900 \mathrm{~L} / \mathrm{s}$. In contrast, the total discharge of hot water from the hydrothermal reservoir is about $300 \mathrm{~L} / \mathrm{s}$. For modeling purposes, the ground-water system is considered as comprising a shallow subsystem in the fill above the densely welded Bishop Tuff containing relatively cold ground water, and a deep subsystem or hydrothermal reservoir in the welded tuff containing relatively hot ground water. Hydrologic, isotopic, and thermal data indicate that recharge to the hydrothermal reservoir occurs in the upper Owens River drainage basin along the western periphery of the caldera. Temperature profiles in a 2.11$\mathrm{km}$-deep test well drilled by private industry in the southeastern part of the caldera suggest that an additional flux of relatively cool ground water recharges the deep subsystem around the northeast rim. Flow in the shallow ground-water subsystem is neglected in the model except in recharge areas and along Hot Creek gorge, where approximately 80 percent of the hot-water discharge from the hydrothermal reservoir moves upward along faults toward springs in the gorge.

Heat-flow data from the Long Valley region indicate that the resurgent dome overlies a residual magma chamber more circular in plan than the original magma chamber that supplied the Bishop Tuff, and lead to the inference that magma beneath the east part of the caldera was exhausted during eruption of the Bishop Tuff. Seismic and teleseismic studies (based on distant earthquakes) also indicate that an anomalously hot or partially molten mass persists below $6-8 \mathrm{~km}$ under the west part of the caldera. Other evidence, including an estimate of present-day heat discharge of $6.9 \times 10^{7} \mathrm{cal} / \mathrm{s}$, implies that the heat source for the hydrothermal system is related to the main magma chamber rather than to any of the postcaldera eruptive volcanics.

Constraints on modeling the natural conditions of heat and fluid flow in the hydrothermal system are provided by applying chemical mixing models to spring discharges and rates of boron discharge into Lake Crowley to yield estimates of $200-300 \mathrm{~kg} / \mathrm{s}$ of water at temperatures between $200^{\circ} \mathrm{C}$ and $280^{\circ} \mathrm{C}$ leaving the reservoir under the area of hot-spring discharge. We also estimate $6.9 \times 10^{7} \mathrm{cal} / \mathrm{s}$ for the total heat discharge at the land surface, based on measurements of spring discharges and temperatures, shallow conductive heat flows, and advective heat losses from warm water discharge into Lake Crowley. Unfortunately, the time over which this heat discharge has persisted is uncertain. Evidence of hydrothermal alteration indicates that hydrothermal activity was present and perhaps more extensive at $0.3 \mathrm{~m}$.y. ago than today, although only relatively recent periods of saline discharge (30,000-40,000 years) from Long Valley can be accounted for by analysis of salts in deposits of Searles Lake, downdrainage from the caldera.

The total amounts of various hot-spring constituents-such as B, $\mathrm{Cl}, \mathrm{Li}$, and $\mathrm{As}-$ which have been contributed to Searles Lake by the 
Long Valley system could have been supplied by leaching of realistic volumes of reservoir rocks. A direct magmatic source would not be required to supply these elements, even considering that an additional Searles Lake-size deposit from a previous period of hydrothermal activity around $0.3 \mathrm{~m} . \mathrm{y}$. ago remains undiscovered.

Our mathematical model of the Long Valley caldera involves a transient, three-dimensional simulation using numerical techniques to solve the appropriate partial differential equations. The model includes five horizontal layers corresponding to the major rock units identified by seismic-refraction and geologic studies. The simulated hydrothermal reservoir is in fractured Bishop Tuff and precaldera basement rocks at depths from 1 to $3 \mathrm{~km}$. Recharge to the reservoir occurs along the caldera ring fault around the west and northeast rims, and discharge occurs at the surface along Hot Creek gorge and at depth through the southeast rim. Estimates of effective reservoir permeability, assuming an equivalent porous-media flow system, were obtained with the model for several variations of reservoir permeability distribution. This was done by assigning pressureboundary conditions in recharge and discharge areas based on water-table altitudes and then adjusting reservoir permeability to yield a throughflow of $250 \mathrm{~kg} / \mathrm{s}$. Intrinsic permeability values from 30 to 50 millidarcys $\left(10-15 \mathrm{~m}^{2}\right)$ were obtained for a 1-km-thick reservoir covering the entire area of the caldera. A permeability of 350 millidarcys was required for the case of a more areally restricted fault zone reservoir. The values obtained are inversely proportional to the simulated reservoir thickness. Comparisons with laboratory results on cores from Long Valley and the Neveda Test Site (NTS), and well tests in fractured, welded tuff at NTS indicate that permeability values obtained from the model analysis represent an integration of the effects of fracture permeability over the volume of the reservoir rock.

Thermal boundary conditions in the model included a constanttemperature distribution at the base, which simulated a magma chamber under the west half of the caldera, and constant temperature at the land surface. Initial temperature conditions were obtained from a steady-state solution with no fluid flow in the reservoir. Simulation of heat and fluid flow for a period of 35,000 years (based on the estimated age of Long Valley salts in Searles Lake) indicates that present-day heat discharge could have been sustained for this period by a magma chamber at $6 \mathrm{~km}$ with fluid circulation to depths from 1.5 to $2.5 \mathrm{~km}$ in a reservoir which is continuous over the area of the caldera. Simulated reservoir temperatures under the Hot Creek gorge area are close to those estimated geothermetrically $\left(200^{\circ} \mathrm{C}-\right.$ $280^{\circ} \mathrm{C}$ ) after 35,000 years, but are only about $80^{\circ} \mathrm{C}$ under the southeastern portion of the caldera as a result of recharge from the northeast rim near Glass Mountain. Cooler temperatures under the eastern caldera are consistent with results from the $2.11-\mathrm{km}$-deep test well drilled in that area.

To sustain hot-spring discharge with present-day heat flow and reservoir temperatures for periods much greater than 35,000 years, deeper levels of fluid circulation would be required. For a period of 350,000 years, at which time the system would have reached steadystate conditions, fluid circulation to at least $4-5 \mathrm{~km}$ would be necessary. Consideration of cellular convection in addition to horizontal throughflow in the hydrothermal reservoir does not significantly alter these results.

The model simulations and the diverse indications of the age of hot-spring activity are consistent with the concept that hydrothermal system has functioned intermittently with considerable periods of inactivity-possibly related to climatic variations and chemical self-sealing processes. Additional data from deep drilling in the western part of the caldera are needed to more satisfactorily delineate the characteristics of the hydrothermal flow system and the caldera's geothermal history and to evaluate the adequacy of the simplified hydrothermal model considered in this study.

\section{INTRODUCTTION INTEREST IN GEOTHERMAL POTENTIAL OF LONG VALLEY}

Geothermal manifestations of Long Valley and adjacent areas have been recognized since the late nineteenth century (Whiting, 1888; Russell, 1889). No attempts to develop the geothermal resource were made, however, until the late 1950's and early 1960's, when several exploratory geothermal wells were drilled at or near Casa Diablo Hot Springs (pl. 1, fig. 2) by Magma Power Company (McNitt, 1963, p. 29; California Division of Oil and Gas, 1972).

Although the deepest exploratory well reached only $324 \mathrm{~m}$, temperatures as high as $180^{\circ} \mathrm{C}$ were recorded (McNitt, 1963, p. 25-29; California Department of Water Resources, 1967). In spite of these favorable indications, no further test drilling was done commercially until 1976, when an exploratory well was drilled by Republic Geothermal, Inc. to a depth of 2,109 $\mathrm{m}$ in the southeastern part of the Long Valley caldera (pl. 1, T3S/R29E-29K, well 66-29). Specific data from the deep well are proprietary but temperatures in the hole were indicated to be too low for conventional generation of electricity and for most nonelectrical uses (W. S. Keys, T. C. Urban, W. H. Diment, and Manuel Mathenson, written commun., 1976).

Meanwhile, chemical analyses of hot waters from the shallower test wells and hot springs indicated a hotwater-type reservoir (White and others, 1971, p. 77-80) with minimum temperatures of $180^{\circ} \mathrm{C}$ on the basis of methods of geothermometry developed by Fournier and Rowe (1966) and Ellis (1970). Calculations by White (1965, table 1) based on relations of boron concentration to heat content of thermal waters indicated a convective heat flow of $7 \times 10^{7} \mathrm{cal} / \mathrm{s}$. According to a recent estimate by Nathenson and Muffler (1975, table 16), Long Valley is one of the largest hydrothermal convection systems in the western United States in terms of potential for electric-power development. In spite of relatively low temperatures found in the Republic Geothermal well, the Long Valley hydrothermal system, or perhaps, the heat stored in the rocks below the depths of significant hydrothermal circulation, are likely to be developed commercially, once the environmental problems associated with such development can be dealt with satisfactorily.

\section{PREVIOUS STUDIES}

Long Valley and surrounding areas have been the subject of many geologic, hydrologic, geophysical, and geochemical studies since the late nineteenth century. The presence of hot springs, young volcanic rocks, and evidence of earlier hydrothermal activity was recognized in the earliest investigations. Among papers de- 
scribing thermal springs and other hydrothermal manifestiations are those of Russell (1889); W. T. Lee (1906); Waring (1915); Stearns, Stearns, and Waring (1937), Blake and Matthes (1938); Waring (1965); and Kaysing (1970).

Early regional geologic studies include those of Mayo (1934), who applied the term "Mammoth embayment" to the L-shaped reentrant in the east face of the Sierra Nevada in what is now considered the west half of the Long Valley caldera, and Gilbert (1941), who summarized the structure and upper Tertiary volcanic rocks of the Long Valley area.

Rhyolites of the so-called "Mammoth embayment" were described by Chelikowsky (1940), whose interpretations of the age and stratigraphic sequence have been greatly modified by later workers. Gilbert (1938) gave the name Bishop Tuff to the extensive rhyolite tuff, chiefly of ash-flow origin, that erupted from vents beneath Long Valley at the time the caldera was formed. Putnam $(1940,1949,1960)$ showed that the Bishop Tuff erupted shortly after the Sherwin glacial stage (probably middle Pleistocene). Sheridan (1965, 1968,1971 ) studied the Bishop Tuff in detail in exposures east and southeast of Long Valley, where he concluded that two major eruptive pulses were represented. Potassium-argon dates for the Bishop were obtained by Dalrymple $(1963,1964)$ and Dalrymple, Cox, and Doell (1965), which ultimately established an age of about $0.7 \mathrm{~m} . \mathrm{y}$. (million years) for the eruptions that formed the Long Valley caldera. Noble, Korringa, Hedge, and Riddle (1972) described the rhyolite at Glass Mountain on the northeast rim of the caldera. Wood (1975) used radiocarbon dating and traceelement correlations to decipher the sequence of late Pleistocene eruptions from the northwest part of the Long Valley caldera northward to the Mono basin.

Geologic mapping of most of the caldera and adjacent areas to the east and west, published at a scale of 1:62,500, was done by Rinehart and Ross $(1957,1964)$, Huber and Rinehart (1965), and Crowder and Sheridan (1972).

In spite of all this and other geologic work, the Long Valley area had not been studied systematically as a unit until a coordinated program of geologic, geophysical, geochemical, and hydrologic investigations was undertaken by the U.S. Geological Survey during 1972-73 (Muffler and Williams, 1976). As a major part of this effort, Bailey, Dalrymple, and Lanphere (1976) presented a synthesis of their work and related studies, which included a tentative model of the caldera system and its evolution. Our present interpretation of the geologic framework of the caldera is based largely on Bailey, Dalrymple, and Lanphere (1976) and on the results of geophysical investigations, which are out- lined below.

The earliest published results of geophysical studies of Long Valley consisted of gravity, seismic, and aeromagnetic surveys in the Mono Basin-Long Valley area (Pakiser and others, 1960). The results of the gravity and magnetic surveys in Long Valley were subsequently summarized by Pakiser (1961). Pakiser, Kane, and Jackson (1964) developed a gravity model of Long Valley and discussed the geologic structure of the valley and its relation to the surrounding geologic features and to the geologic history of the Sierra Nevada and the Basin and Range provinces. Further refinements of gravity and magnetic interpretations were made by Kane and Mabey (1973), and by Kane, Mabey, and Brace (1976a, 1976b). These studies indicated a steep-sided caldera having a porous fill possibly $3 \mathrm{~km}$ in thickness. The magnetic results indicated a more magnetic fill in the eastern part of the caldera than in the western part.

Seismic-refraction studies (Pakiser, 1968; Hill and others, Pakiser, 1973; Hill, 1976) have strongly supplemented the gravity and magnetic studies in delineating caldera geometry and showing the major structural and stratigraphic features of the caldera fill. Gross stratigraphic features inferred from seismicrefraction profiles have been corroborated by totalfield-resistivity surveys, direct-current soundings, and electromagnetic soundings, which also were successful in outlining zones of low resistivity that correlate with known hot springs or with zones of hydrothermal alteration (Jackson and others, 1973; Stanley and others, 1973, 1976). Shallow resistivity anomalies were explored by an audiomagnetotelluric system, which identified two linear zones of low resistivity associated with hot springs and hydrothermally altered rocks (Hoover and others, 1973, 1976). Spontaneous (self) potential surveys indicated streaming potential attributed to upward flow of thermal ground water in the westcentral part of the caldera and downward flow in areas to the north and west (Anderson and Johnson, 1973, 1976).

A seismic-noise survey indicated the possible presence of geothermal noise beneath Long Valley (Iyer and Hitchcock, 1976). Microearthquakes were recorded for only a brief period in 1973 (Steeples and Pitt, 1973, 1976). The record showed activity only at the southeast edge of the caldera, at a depth of $10 \mathrm{~km}$, possibly on the Hilton Creek fault. A longer record might have shown activity elsewhere. Studies of teleseismic events (distant earthquakes) indicated delays of $P$-wave arrivals attributed to presence of low-velocity material beneath the west-central part of the caldera, at depths between 7 and $40 \mathrm{~km}$ (Steeples and Iyer, 1976).

Heat-flow studies-Lachenbruch $(1968,1970)$; 
Lachenbruch, Lewis, and Sass (1973); Sass, Lachenbruch, and Munroe (1974); Lachenbruch, Sass, Monroe, and Moses (1976); Lachenbruch, Sorey, Lewis, and Sass (1976); Sorey and Lewis (1976) --were based on 11 temperature-gradient test holes located from 0 to 30 $\mathrm{km}$ outside the caldera rim and ranging in depth from 113 to $271 \mathrm{~m}$, and also on 40 test holes drilled to depths from 5 to $325 \mathrm{~m}$ within the caldera for hydrologic as well as heat-flow information. The heat-flow studies, which are discussed in a later section, generally placed constraints on our interpretation of the magmatic history of the caldera and of the effects of ground-water movement on near-surface heat flows in the caldera.

The first significant subsurface geologic and geochemical data in the caldera were obtained from nine geothermal test wells drilled at Casa Diablo Hot Springs and one well drilled about $5 \mathrm{~km}$ farther east between 1959 and 1964 by Magma Power Company (McNitt, 1963, p. 29). The wells ranged in depth up to $324 \mathrm{~m}$, and the highest temperature recorded was about $180^{\circ} \mathrm{C}$ (California Dept. of Water Resources, 1967).

The first hydrologic investigation for which published data are available was that of W. T. Lee (1906). Although primarily concerned with the geology and water resources of the Owens Valley, Lee discussed the volcanic features and the thermal activity of the Long Valley area. C. H. Lee (1912) also discussed the water resources of the Owens Valley; although he presented no data for Long Valley, he did include data on precipitation, streamflow, evaporation, transpiration, and infiltration which are valid, with some modification, for Long Valley. Lewis (1974) presented basic data on springs and wells in the Valley. Sorey (1975b) described the effects of potential geothermal development on the springs at Hot Creek Fish Hatchery.

Geochemistry of the thermal waters in the caldera was investigated by Willey, O'Neil, and Rapp (1974); and Mariner and Willey (1976). In addition, estimates of reservoir temperatures and convective heat discharge from the caldera on the basis of chemical data were made by White (1965); White, Muffler, and Truesdell (1971); Sorey and Lewis (1976); and Mariner and Willey (1976). Studies of isotopes of hydrogen and oxygen by Mariner and Willey (1976) and Friedman and Smith $(1970,1972)$ indicated possible sources of meteoric recharge water and have assisted in delineation of the mixing of thermal and nonthermal waters in the caldera.

Qualitative results from the Republic Geothermal, Inc. well 66-29 (pl. 1, T3S/R29E-29K), which are generally known within the geothermal industry and are discussed in subsequent sections of this report, include identification of the top of the welded Bishop Tuff at
$0.85 \mathrm{~km}$ and a lack of evidence for basement rocks above the drilled total depth of $2.11 \mathrm{~km}$. Selected samples from the drill cuttings were analyzed for grain density, and one fluid sample was obtained from a drill stem test for analysis of chlorine and stable isotope contents. White (1976, written commun.) suggests, on the basis of the relatively low temperatures measured throughout the drilled interval and previous geologic, geophysical, and geochemical data, that the eastern 40 percent of the caldera is eliminated as an attractive hydrothermal resource, but that the western 60 percent continues to have major potential.

\section{SCOPE OF PRESENT STUDY}

The purpose of the present study was to synthesize previous geologic, geophysical, geochemical, and hydrologic investigations of the Long Valley caldera and to derive one or more generalized conceptual and mathematical models of the hydrothermal system. Although fairly abundant areal geologic, surface-geophysical, and geochemical data were available, subsurface drill-hole information, with one exception, was limited to depths less than about $300 \mathrm{~m}$. Thus, any conceptual model must be an oversimplification at this stage. The model analyzed in this study is consistent with constraints provided by the results of the recent deep test well, previous geologic and geophysical studies, and estimates of heat and fluid discharge from the caldera. Thus, we believe that the gross features of the hydrothermal system are adequately quantified in the model. However, because data from additional deep drilling could suggest necessary changes and refinement in the conceptual model, we present the following analysis more as an illustration of the usefulness of numerical simulation techniques, rather than as a unique representation of the Long Valley hydrothermal system.

The ultimate goal of this modeling effort is to satisfactorily evaluate the potential for energy development, the optimum methods for that development, and the extent to which development can proceed without unacceptable effects on other resources in the Long Valley area. The modeling study presented in this report involves a three-dimensional, transient analysis of the natural thermal and hydrologic conditions within the caldera. As additional detail from deep test drilling becomes available, this basic model can be modified and refined to permit analysis of the energy development problem.

\section{ACKNOWLEDGMENTS}

The writers express their appreciation to R. A. Bailey, A. H. Lachenbruch, D. E. White, and R. O. 
Fournier of the U.S. Geological Survey for contributing information, insights, and discussions on Long Valley. We are also grateful to R. H. Mariner, R. J. Munroe, T. H. Moses, J. G. Blevins, and N. E. Voegtly for their assistance and cooperation in the collection and analysis of field data. We acknowledge the cooperation of Republic Geothermal, Inc. in providing access to, and information from, their deep test well. We also benefited from access to temperature data obtained by W. S. Keys, T. C. Urban, W. H. Diment, and Manuel Nathenson of the U. S. Geological Survey.

In addition, comments by A. F. Moench, Manuel Nathenson, J. W. Mercer, and F. W. Trainer were valuable in encouraging further analysis and emphasizing that this explanation of the Long Valley Hydrothermal system is not unique.

\section{WELL AND SPRING NUMBERING SYSTEM}

Wells and springs are assigned numbers according to their location in the rectangular system for the sub- division of public land. For example, as shown in figure 1 , in the number $3 \mathrm{~S} / 29 \mathrm{E}-2 \mathrm{~A} 1$, the part of the number preceding the slash indicates the township (T $3 \mathrm{~S}$.), the part between the slash and the dash indicates the range (R. 29 E.), the number between the dash and the letter indicates the section (sec. 2), and the letter indicates the 40 -acre subdivision of the section.

Within the 40-acre tract wells are numbered serially, as indicated by the final digit. Thus, well $3 \mathrm{~S} /$ $29 \mathrm{E}-2 \mathrm{~A} 1$ is the first well to be listed in the NE1/4: NE1/4 sec. 2, T. 3 S., R. 29 E., Mount Diablo base line and meridian. Springs are numbered similarly except that an $\mathrm{S}$ is placed between the 40 -acre subdivision letter and the final digit, as shown in the following spring number: $3 \mathrm{~S} / 28 \mathrm{E}-35 \mathrm{ES} 1$.

The letter $\mathrm{Z}$, substituted for the letter designating the 40 -acre tract, indicates the well or spring was plotted from unverified descriptions; the described locations of such wells or springs were visited, but the data could not be correlated with existing wells or springs.

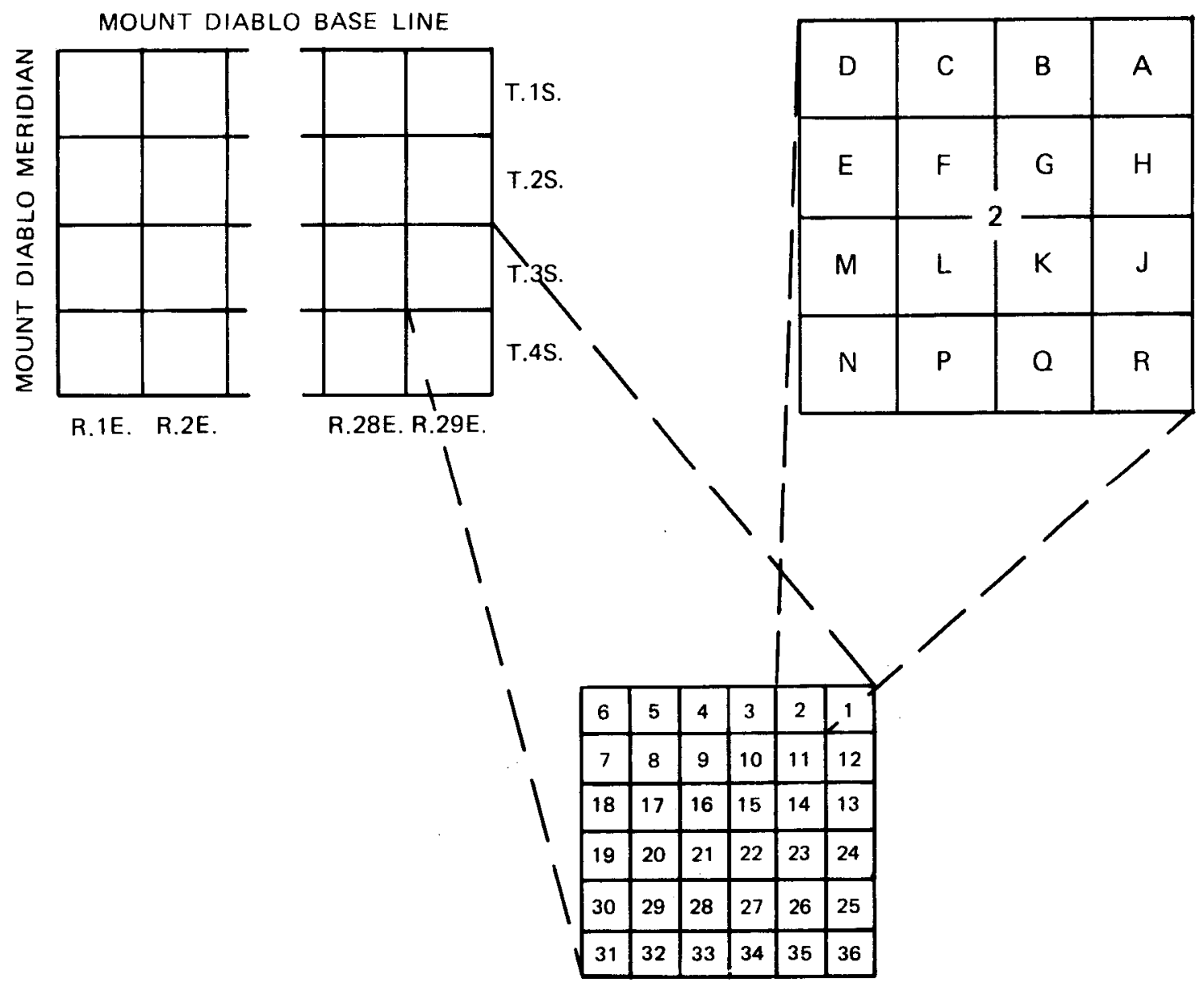

T.3S./R.29E. $-2 A 1$

Figure 1.-Diagram of system for numbering wells and springs. 
TABLE 1.-Conversion factors between metric and English units

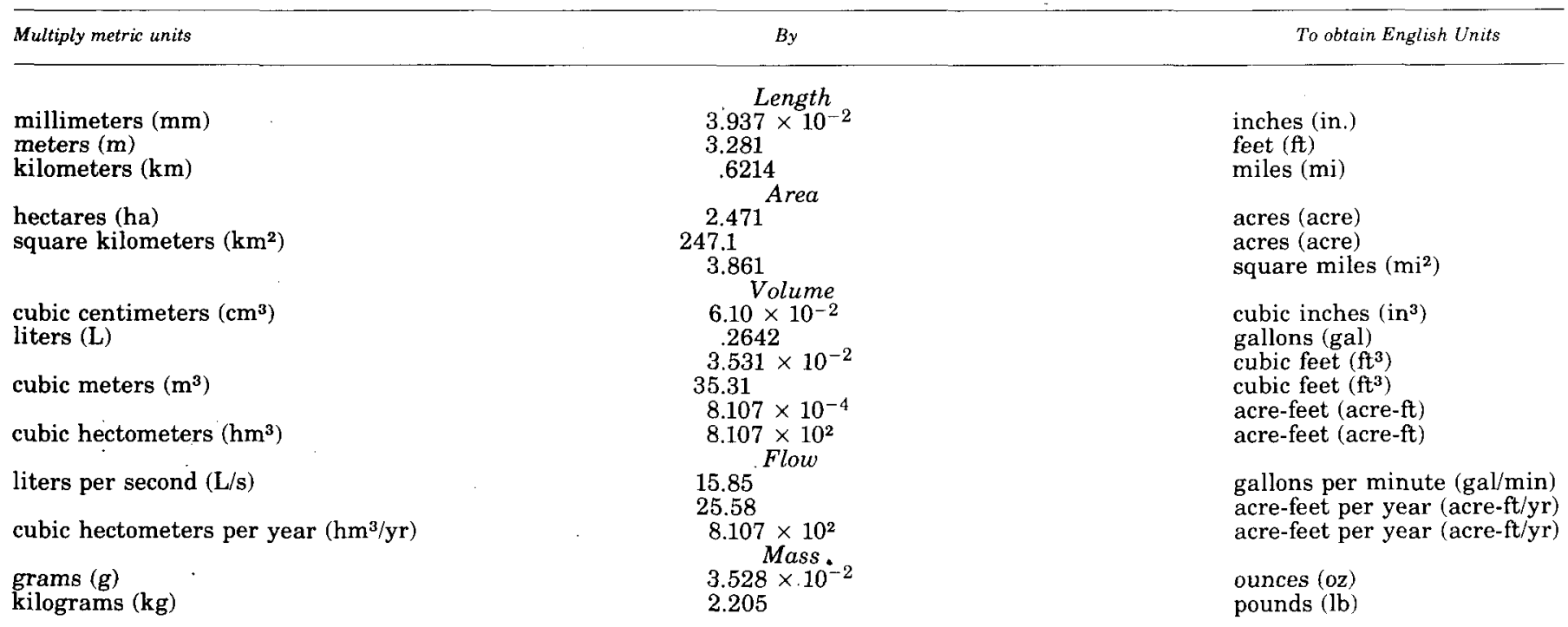

Temperature: degrees Celsius to degrees Fahrenheit- ${ }^{\circ} \mathrm{F}=1.8^{\circ} \mathrm{C}+32$

Thermal Parameters

Multiply "working units" By obtain SI units

millicalories per centimeter second $\cdot$ degree

(m cal $/\left(\mathrm{cm} \mathrm{s}^{\circ} \mathrm{C}\right)$ )

square centimeters per second $\left(\mathrm{cm}^{2} / \mathrm{s}\right)$

microcalories per square centimeter 'second $\left(\mathrm{cal} /\left(\mathrm{cm}^{2} \cdot \mathrm{s}\right)\right)$

heat-flow unit (HFU)

calories (cal)

calories per second (cal/s)
Thermal conductivity

$$
0.4187
$$

Thermal diffusivity

$$
1.0 \times 10^{-4}
$$

Heat flow (Heat-flux density)

$$
4.187 \times 10^{-2}
$$

$$
\begin{gathered}
\text { Energy } \\
4.187 \\
\text { Heat discharge } \\
4.187
\end{gathered}
$$

watts per meter degree

Kelvin

$\left(\mathrm{W} /\left(\mathrm{m} \cdot{ }^{\circ} \mathrm{K}\right)\right)$

square meters per second $\left(\mathrm{m}^{2} / \mathrm{s}\right)$

watts per square meter $\left(\mathrm{W} / \mathrm{m}^{2}\right)$

joules (J)

watts (W)

\section{CONVERSION OF UNITS}

The metric system is used throughout this report, although some of the original measurements and data were reported in English units. Thermal parameters are given in the more familiar "working units" rather than in the now-standard SI (Systeme Internationale) units. Table 1 lists metric and equivalent English units, and "working units" and equivalent SI units for the thermal parameters.

\section{GEOLOGIC SETTING LOCATION AND GENERAL FEATURES}

The Long Valley caldera is in east-central California, in southern Mono County, about 40-70 km north- west of Bishop (fig. 2). The caldera floor is elliptical in plan, 17 by $30 \mathrm{~km}$, with its long axis aligned east-west. The area of the floor is about $450 \mathrm{~km}^{2}$, and the total area of the caldera and its tributary drainage basins is about $830 \mathrm{~km}^{2}$.

The caldera margin (pl. 1) is formed by the Sierra Nevada on the south and west, by a prominent ridge from Bald Mountain to Glass Mountain on the north, and by an unnamed dissected volcanic tableland on the east. Altitudes along the rim range from as low as $2,420 \mathrm{~m}$ in the northwest and $2,067 \mathrm{~m}$ at Lake Crowley (spillway level) in the southeast to $3,390 \mathrm{~m}$ at Glass Mountain in the northeast, $3,823 \mathrm{~m}$ at Bloody Mountain in the south, and $3,367 \mathrm{~m}$ at Mammoth Mountain in the southwest. 
Long Valley proper occupies the lower, eastern twofifths of the caldera. The higher, western three-fifths of the caldera includes a complex series of postcaldera rhyolite flows which have been arched and subsequently faulted to form a resurgent dome 10-12 km in diameter. The annular moat between the resurgent dome and the caldera rim is occupied in the north, west, and south by still younger rhyolitic to basaltic lavas and in the east chiefly by alluvial and lacustrine deposits. Altitudes within the area of the caldera floor range from $2,067 \mathrm{~m}$ at Lake Crowley in the southeast to $2,860 \mathrm{~m}$ at the summit of a lava dome within the southwest moat. The resurgent dome rises to maximum altitude of $2,545 \mathrm{~m}$ at Lookout Mountain in the northern part, or about $340-460 \mathrm{~m}$ above the floor of the adjacent moat.

The caldera is drained by the Owens River, which flows eastward across its northern part and then southward into Lake Crowley, and by several tributaries around the periphery. Mammoth, Hot, and Convict Creeks are the chief tributaries, flowing generally eastward across the southern part of the caldera into Lake Crowley. Drainage on the resurgent dome has a roughly radial pattern.

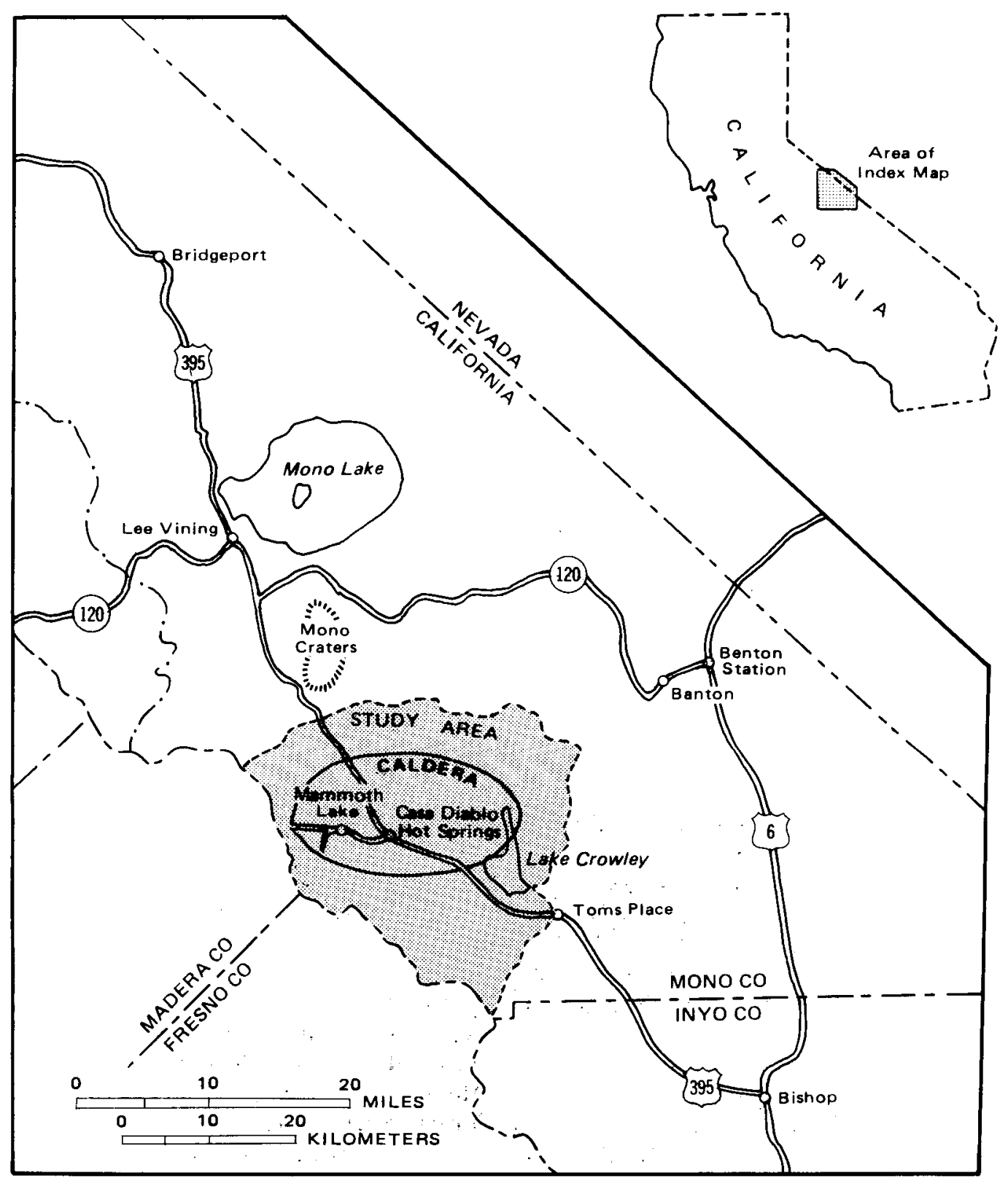

Figure 2.-Index map showing location of Long Valley area. 


\section{GEOLOGIC HISTORY}

The events described below are based chiefly on an interpretation of the geologic history of the Long Valley caldera by Bailey, Dalrymple, and Lanphere (1976), whose work included geologic mapping, sampling, potassium-argon dating on rock samples carefully selected to provide maximum information about the sequence of eruptive events, petrologic studies, preliminary petrographic work, and studies of preexisting petrochemical data. Although some of the conclusions are tentative, the general outline of the history is believed to be reasonably well understood.

Cenozoic volcanism in the region now occupied by the Long Valley caldera began about $3.2 \mathrm{~m}$.y. ago with the eruption of basalt and andesite from widely scattered centers. The earliest eruptions were followed 3.0 to $2.7 \mathrm{~m} . \mathrm{y}$. ago by eruption of rhyodacite (quartz latite) from the Two Teats-San Joaquin Mountain and Bald Mountain areas. All these events probably happened during the latter stages of the last major uplift of the Sierra Nevada.

Lindgren (1911), Matthes (1930, 1933, 1939, 1947), Dalrymple $(1963,1964)$, Bateman and Wahrhaftig (1966), Christensen (1966), and others believed that the Sierra Nevada crest reached approximately its present height by the time of the earliest glaciation of the Pleistocene, and that the formation of the eastern escarpment of the Sierra followed the last major uplift. A different interpretation was reached by Piper, Gale, Thomas, and Robinson (1939), Axelrod and Ting (1961), Axelrod (1962), and Putnam (1962), who inferred that the last major uplift was middle Pleistocene or later. The prepondrance of evidence, however, supports the views of Lindgren, Matthes, and later workers cited above. In any event, the inference seems reasonable that the earliest volcanic activity in the Sierra crestal region was related to the initiation of major normal faulting that downdropped the area to the east.

The next volcanic episode was the eruption of highly silicic rhyolite along an arcuate zone $13 \mathrm{~km}$ in length northeast of the present Long Valley caldera in the general vicinity of Glass Mountain. The arcuate zone probably is coincident with an incipient ring fracture related to the earliest stages of the development of the Long Valley magma chamber. The rhyolitic eruptions began at least 1.9 m.y. ago and were episodic to about 0.9 m.y. ago.

The major event that resulted in the formation of the Long Valley caldera took place about $0.7 \mathrm{~m}$.y. ago with the eruption of $600 \mathrm{~km}^{3}$ or more of rhyolite from the upper part of a magma chamber beneath Long Valley. The eruptions included two major pulses and occurred chiefly as ash flows. Because of the withdrawal of such a large volume of material, the roof of the magma chamber collapsed along one or more steeply inclined ring fractures, forming the present caldera. The amount of subsidence was at least $1 \mathrm{~km}$, and the elliptical depression thus formed measured about $29 \mathrm{~km}$ in an east-west direction by about $15 \mathrm{~km}$ north-south.

Rhyolite erupted intermittently from at least 12 vents near the center of the caldera, about 40,000 to 100,000 years after the collapse that formed the caldera. During the eruptions the west-central part of the caldera floor was uplifted to form a subcircular resurgent dome about $10 \mathrm{~km}$ in diameter. At the same time, the crest of the dome foundered along northnorthwest-trending faults to form a keystone graben 5 $\mathrm{km}$ wide.

The depression formed by the caldera collapse rapidly filled with water to form Long Valley Lake. The lake reached a high level of more than $2,320 \mathrm{~m}$ above sea level, and the early rhyolites of the resurgent dome probably erupted into the lake. Relations of lake-terrace deposits, strand lines, and perlitized or hydrated zones in rhyolites to radiometrically dated volcanic rocks indicate that the lake receded at irregular rates and finally was drained completely by downcutting of its outlet sometime within the last 100,000 years. Recent discovery that basaltic ash in lakebeds in the southeast part of the caldera is similar to that at Black Point in the Mono Basin, which has been dated at 13,500 years before present, suggests the presence of a shallow lake as recently as $10,000-15,000$ years ago (Roy Bailey, oral commun., 1976).

After the formation of the resurgent dome about 0.7 to $0.6 \mathrm{~m}$.y. ago, porphyritic rhyolite erupted from three groups of centers in the moat between the resurgent dome and the walls of the caldera. The eruptions occurred at $0.2 \mathrm{~m} . \mathrm{y}$. intervals about $0.5,0.3$, and $0.1 \mathrm{~m} . \mathrm{y}$. ago, starting in the north moat and proceding in clockwise succession around the resurgent dome to the southeast and then the west moat.

Porphyritic rhyodacite (quartz latite) erupted on the southwest rim of the caldera and near the base of the north-west-north caldera walls beginning about 0.2 m.y. ago and ending about 0.05 m.y. ago. The silica content of these lavas, about 59-74 percent, averages lower than that of the earlier rhyolitic rocks, which suggests derivation from a lower level in the differentiated and stratified magma chamber. Mammoth Mountain, on the southwest caldera rim, was the largest center of these eruptions.

During the same period as the eruptions of rhyodacites of the caldera rim and the latest eruptions of rhyolite in the west moat, basaltic to trachyandesitic 
flows and cinder cones erupted in the west moat about 0.2 to $0.06 \mathrm{~m}$.y. ago. These mafic to intermediate volcanic rocks are part of a more extensive chain which decreases in age northward from 0.9 m.y. in the Devil's Postpile area southwest of the caldera to about 0.013 m.y. at Black Point on the north shore of Mono Lake. Chemically and mineralogically, these rocks are similar to many other Cenozoic rocks east of the Sierra Nevada in the Basin and Range province, and they may not be related directly to the Long Valley magma chamber.

The most recent volcanic events in the Long Valley caldera were the eruptions of the rhyolite and rhyodacite of the Inyo craters and domes. These features are alined on an apparent north-trending fracture along the east front of the Sierra Nevada from the west moat of the Long Valley caldera northward to the Mono Craters. The youngest of the five lava domes in less than 720 years old (Wood, 1975), and the Inyo Craters, which comprise three phreatic explosion pits on the south side of Deer Mountain, suggest the possible presence of rhyodacitic magma in the Long Valley magma chamber as recently as 450 years ago.

\section{CHARACTERISTICS OF CALDERA}

The present dimensions of the caldera floor result from enlargement of the original caldera by slope retreat of walls caused by slumping and erosion; the main ring fracture lies within the caldera moat (Bailey and others, 1976, p. 731). (See fig. 3.)

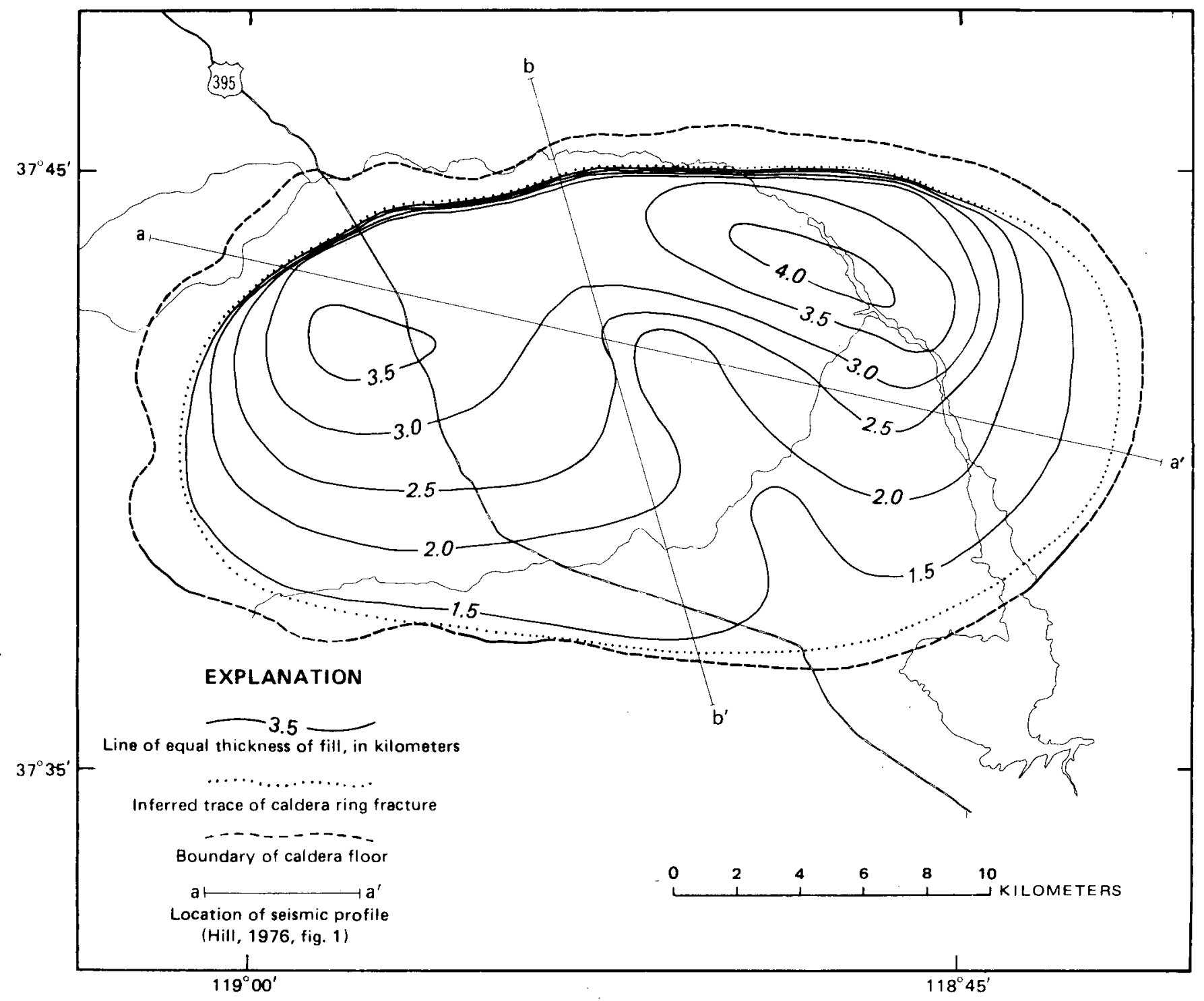

Figure 3.-Map showing thickness of fill in Long Valley caldera. 
The caldera probably subsided along a single steeply dipping ring fault (Roy Bailey, oral commun., 1976). We infer a position of the ring fault midway across the steepest part of the Bouguer gravity gradient. The area encompassed within the surface trace of the ring fault is $269 \mathrm{~km}^{2}$ (fig. 4). The fracture is assumed to dip $80^{\circ}$ inward.

Precaldera basement rocks have a seismic P-wave velocity of $6.0 \mathrm{~km} / \mathrm{s}$ (Hill, 1976). We infer that the basement surface beneath the caldera is the lower (B) horizon on the seismic-refraction profiles of Hill (1976, figs. 7 and 8).

The layer overlying basement in the caldera, which has a P-wave velocity from 4.0 to $4.4 \mathrm{~km} / \mathrm{s}$ (Hill, 1976), probably comprises densely welded Bishop Tuff and underlying volcanic and sedimentary(?) rocks that predate caldera collapse (rhyolite of Glass Mountain and, possibly, volcanic rocks of Pliocene age). Most of the Bishop Tuff within the caldera is believed to be densely welded (Roy Bailey, oral commun., 1976), as was found to be the case in the Republic Geothermal, Inc. well 66-29 (pl. 1).

The layer overlying probable welded Bishop Tuff within the caldera, which has a $\mathrm{P}$-wave velocity ranging from 2.6 to $3.4 \mathrm{~km} / \mathrm{s}$, is believed to comprise rhyolites and rhyodacites of the caldera moat (Hill, 1976, $p$. 750), and, possibly, also basalt (Deadman Creek area) and tuffs intercalated with the flows.

The top seismic layer, which has a P-wave velocity from 1.5 to $1.9 \mathrm{~km} / \mathrm{s}$ (Hill, 1976), probably comprises unconsolidated epiclastic and volcaniclastic deposits and soft pumiceous tuffs.

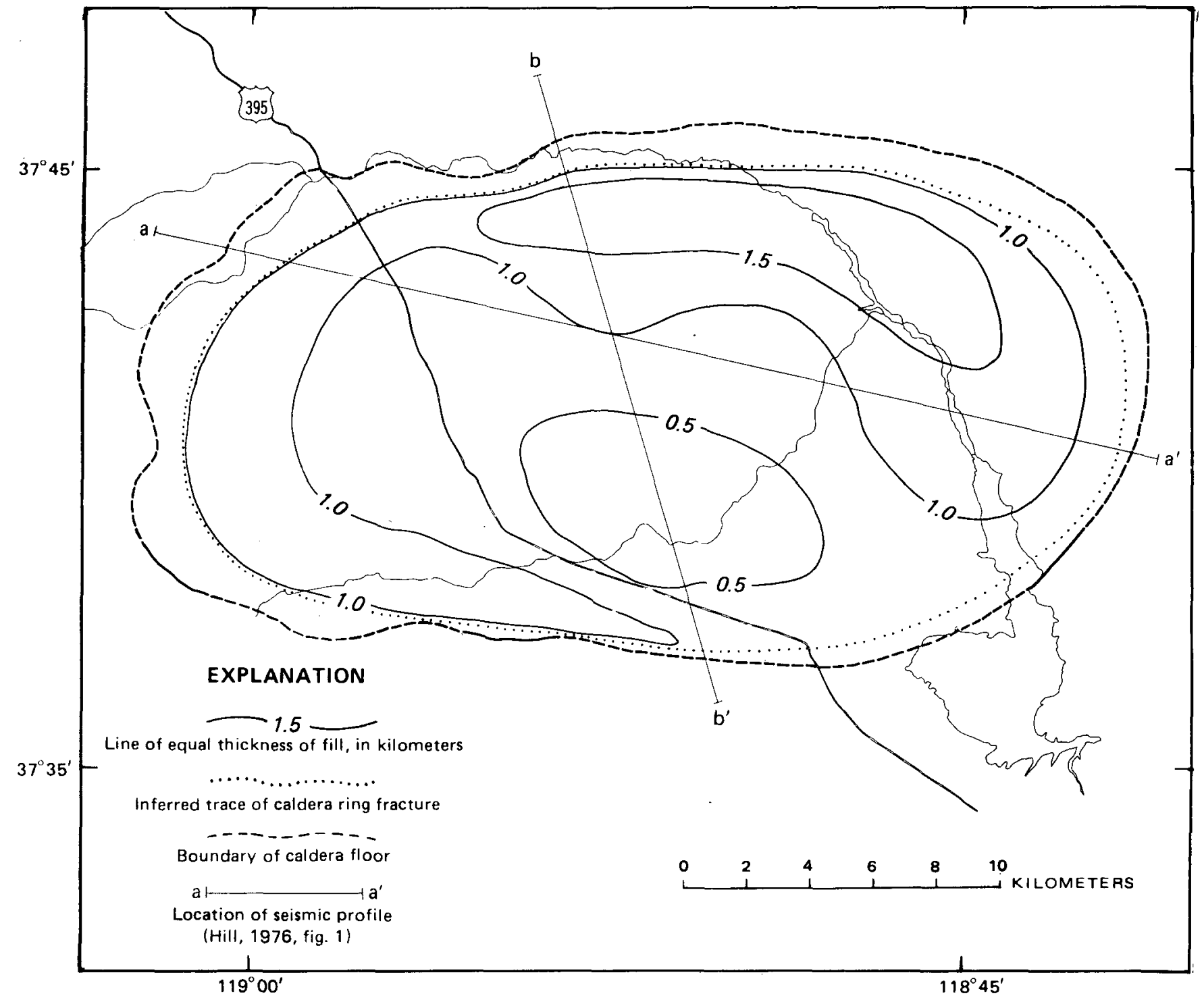

Figure 4.-Map showing thickness of fill above densely welded part of Bishop Tuff in Long Valley caldera. 
We used seismic sections $A^{\prime}-A^{\prime}$ and $B^{\prime}-B^{\prime}$ of Hill (1976, figs. 7 and 8 ) for primary control in constructing the isopachous maps of caldera fill (figs. 3 and 4, lines $a-a^{\prime}$ and $b-b^{\prime}$ ). Isopachs were extended into adjacent parts of the caldera on the basis of an interpretation of gravity data of Kane, Mabey, and Brace (1976a, b). The two gravity lows in the north-central part of the caldera (Kane and others, $1976 \mathrm{a}$, b, fig. 2) probably reflect in part thicker caldera fill and in part material having lower density than that in surrounding areas. We estimate the maximum thickness of caldera fill to be about $4 \mathrm{~km}$ near the eastern gravity low and about 3.5 $\mathrm{km}$ near the western low. Thickness of fill above the densely welded Bishop Tuff (fig. 4) was estimated by a procedure similar to that used for estimating total thickness of fill, except that little use could be made of the gravity data of Kane, Mabey, and Brace (1976a, b), and the isopachs were extended from the seismic sections chiefly on the basis of inferences made by Bailey (1974; oral commun., 1976) as to the location and amount of uplift on the resurgent dome.

Total volume of caldera fill and volume of fill above the welded Bishop Tuff were computed by planimetering the isopachs shown in figures 3 and 4 . Incremental volumes were computed as the product of the thickness increment and the geometric mean of the areas enclosed by the two bounding isopachs. The volumes thus calculated then were added to obtain the total volume of fill, as in table 2.

Our estimate of the total volume of fill, $868 \mathrm{~km}^{3}$, is somewhat greater than the $810 \mathrm{~km}^{3}$ estimated by Muffler and Williams (1976). The difference between the two estimates is due chiefly to the greater thickness of fill along the margin of the caldera inferred from our analysis than that inferred by Muffler and Williams (1976, fig. 2). In their interpretation, Muffler and Williams placed more emphasis on the gravity data; in the present analysis, we placed more emphasis on the seismic results of Hill (1976).

In modeling the hydrothermal system, it is useful to know the average bulk density and porosity of the caldera fill. Average bulk density of the fill is computed as

$$
\rho_{b}=\frac{\rho_{m} V-M_{o}}{V}
$$

where $\rho_{m}$ is the bulk density of the rocks surrounding the caldera $\left(2.67 \mathrm{~g} / \mathrm{cm}^{3}\right), V$ is the volume of fill $(8.68 \times$ $10^{17} \mathrm{~cm}^{3}$ ), and $M_{o}$ is the mass deficiency calculated by Gauss' theorem from the residual gravity anomaly $\left(3.33 \times 10^{17} \mathrm{~g}\right.$; Kane and others, 1976 , p. 759$)$. Substituting these values we obtain an average wet bulk density of the caldera fill of $2.29 \mathrm{~g} / \mathrm{cm}^{3}$.
Average bulk porosity of caldera fill is calculated as

$$
\phi=\frac{\rho_{g}-\rho_{b}}{\rho_{g}-\frac{\rho_{w}}{\rho_{w}}}
$$

where $\phi$ is porosity (dimensionless), $\rho_{g}$ is grain density, $\rho_{b}$ is wet bulk density, and $\rho_{w}$ is density of interstitial water.

Average grain density of the caldera fill cannot be estimated within narrow limits from available data. Sheridan (1965) found an average grain density of 2.45 $\mathrm{g} / \mathrm{cm}^{3}$ on the basis of specific-gravity and porosity measurements for 51 samples of ashflow tuff from outcrop areas of the Bishop Tuff southeast of Long Valley. The standard deviation from the mean density of Sheridan's samples was only $0.01 \mathrm{~g} / \mathrm{cm}^{3}$, even though bulk density ranged widely, from 0.79 to $2.38 \mathrm{~g} / \mathrm{cm}^{3}$. However, an average grain density of $2.65 \mathrm{~g} / \mathrm{cm}^{3}$ was measured by the Survey's Hydrologic Laboratory for cuttings of densely welded Bishop Tuff from the Republic Geothermal test well. Muffler and Williams (1976, p. 723 ) assumed values of 2.50 and $2.60 \mathrm{~g} / \mathrm{cm}^{3}$ on the basis of inferred equivalence values of the Bishop Tuff to those from two ash-flow tuffs from the Creede caldera,

\begin{tabular}{|c|c|c|}
\hline $\begin{array}{c}\text { Depth range } \\
(\mathbf{k m})\end{array}$ & $\begin{array}{l}\text { Area with shallower } \\
\text { isopach } \\
\left(\mathrm{km}^{2}\right)\end{array}$ & $\begin{array}{c}\text { Volume } \\
\left(\mathrm{km}^{3}\right)\end{array}$ \\
\hline $\begin{array}{r}\text { Total volu } \\
0-1.0 \\
1.0-1.5 \\
1.5-2.0 \\
2.0-2.5 \\
2.5-3.0 \\
3.0-3.5 \\
3.5-4.0 \\
>4.0\end{array}$ & $\begin{array}{r}369 \\
357 \\
324 \\
224 \\
159 \\
111 \\
36 \\
6\end{array}$ & $\begin{array}{r}363 \\
170 \\
135 \\
94 \\
66 \\
32 \\
7 \\
1\end{array}$ \\
\hline \multicolumn{3}{|c|}{$\begin{array}{l}0->4.0 \\
\text { Average thickness }=868 \mathrm{~km}^{3} / 369 \mathrm{~km}^{2}=2.35 \mathrm{~km}\end{array}$} \\
\hline \multicolumn{3}{|c|}{ Volume of fill above densely welded Bishop Tuff: } \\
\hline $0 .-0.5$ & 369 & 174 \\
\hline $0.5-1.0$ & 330 & 119 \\
\hline $1.0-1.5$ & 172 & 42 \\
\hline$>1.5$ & 42 & 6 \\
\hline $0 \rightarrow>1.5$ & & 341 \\
\hline
\end{tabular}
Colorado (Ratté and Steven, 1967).

Average thickness $=341 \mathrm{~km}^{3} / 369 \mathrm{~km}^{2}=0.92 \mathrm{~km}$

Volume of densely welded Bishop Tuff and older fill $=868 \mathrm{~km}^{3}-341$ $\mathrm{km}^{3}$

Average thickness 
In calculating bulk porosity, we use a lower limit of $2.45 \mathrm{~g} / \mathrm{cm}^{3}$ and an upper limit of $2.65 \mathrm{~g} / \mathrm{cm}^{3}$ for the average grain density of the caldera fill. Wet bulk density of the fill is $2.29 \mathrm{~g} / \mathrm{cm}^{3}$, as calculated above. Density of interstitial water is taken as $0.96 \mathrm{~g} / \mathrm{cm}^{3}$ on the basis of an assumed average temperature of $100^{\circ} \mathrm{C}$. Bulk porosity, therefore, ranges from 0.11 to 0.21 .

Both theoretical considerations and empirical evidence suggest that porosity is not uniformly distributed throughout the caldera fill. In the following analysis, lateral variations in porosity are not considered. However, the average porosity of the densely welded Bishop Tuff and possible underlying older rocks is believed to be much less than that of the post-Bishop caldera fill.
In the analysis below, we assume, on the basis of test-drilling and seismic-refraction results, that onehalf of the caldera fill above the densely welded Bishop Tuff consists of flows having a porosity of 0.10 and that the other half consists of tuffs and sedimentary rocks having a porosity of 0.45 (see table 5). The average porosity of the post-Bishop caldera fill is, therefore, 0.28 . The average porosity of the densely welded Bishop Tuff and older fill is computed as

$$
\phi=\frac{\phi_{1} Z_{1}-\phi_{2} Z_{2}}{Z_{1}-Z_{2}}
$$

where $\phi_{1}=$ bulk porosity of total fill, $\phi_{2}=$ bulk porosity of post-Bishop caldera fill, $Z_{1}=$ average thickness of total fill, and $Z_{2}=$ average thickness of post-

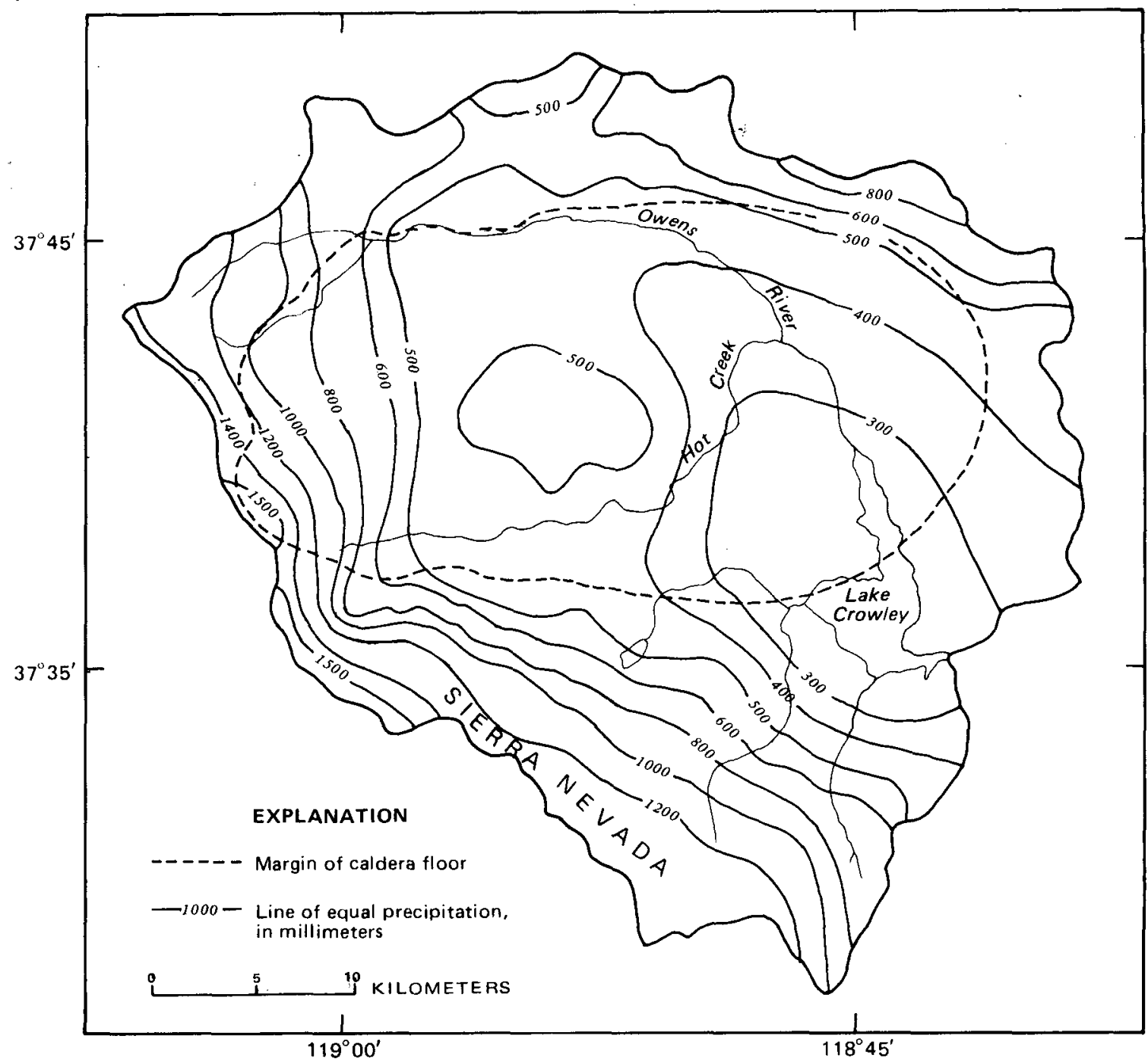

Figure 5.-Map showing average annual precipitation in the Long Valley basin. Data obtained from Rantz (1972) for altitudes above $3,000 \mathrm{~m}$, and from estimates of annual precipitation at 71 locations with altitudes below $3,000 \mathrm{~m}$ derived from U.S. Weather Service climatological records and the work of Spreen (1947). 
Bishop caldera fill. For a range in total fill porosity of $0.11-0.21$, we obtain the average porosity of the welded Bishop Tuff in the range from 0.00 to 0.16 .

These values, being residuals in a series of calculations involving uncertain assumptions, do not help significantly to define the probable. average bulk porosity of the densely welded Bishop Tuff within the caldera. More useful information consists of published values for porosity of the welded phase of the Bishop Tuff in exposures southeast of Long Valley, which range from 0.026 to 0.079 (Gilbert, 1938, Bateman, 1965). Because these values are for small volumes of samples collected in the field, they probably do not include significant fracture porosity, which would be present in much larger volumes of rock. The bulk porosity of welded Bishop Tuff in the areas of exposures may, therefore, be somewhat higher than the published values. However, within the caldera, because of the greater probable thickness of the Bishop Tuff than outside the caldera, and because of the overburden, which averages nearly $1 \mathrm{~km}$ in thickness, the average bulk porosity of the densely welded Bishop Tuff probably is no greater than the higher published values. In our model, discussed in a later section, we use a porosity of 0.10 for the upper part of the densely welded
Bishop Tuff (layer 2, table 14) and 0.05 for the lower part (layer 3, table 14).

\section{HYDROLOGIC SETTING}

\section{CLIMATE AND PRECIPITATION}

The climate in the Long Valley region is influenced greatly by the Sierra Nevada. Precipitation is derived chiefly from storms that originate over the Pacific Ocean and move eastward. About 70-80 percent of the total precipitation in the mountains and a somewhat smaller proportion in the caldera falls as snow from November through April. The remainder falls primarily during local warm-season thunderstorms. Because of the orographic effect of the Sierra Nevada, a "shadow" effect is produced east and north of the crest, and precipitation in the caldera is less than near the crest. Average annual precipitation within the Long Valley drainage basin ranges from more than 1,500 $\mathrm{mm}$ along a part of the Sierra Nevada crest to less than $300 \mathrm{~mm}$ on Lake Crowley, in the southeast part of Long Valley (fig. 5). Variations in annual precipitation from year to year are substantial, as indicated by data for stations at Lake Mary Store and Long Valley Dam (fig. 6).
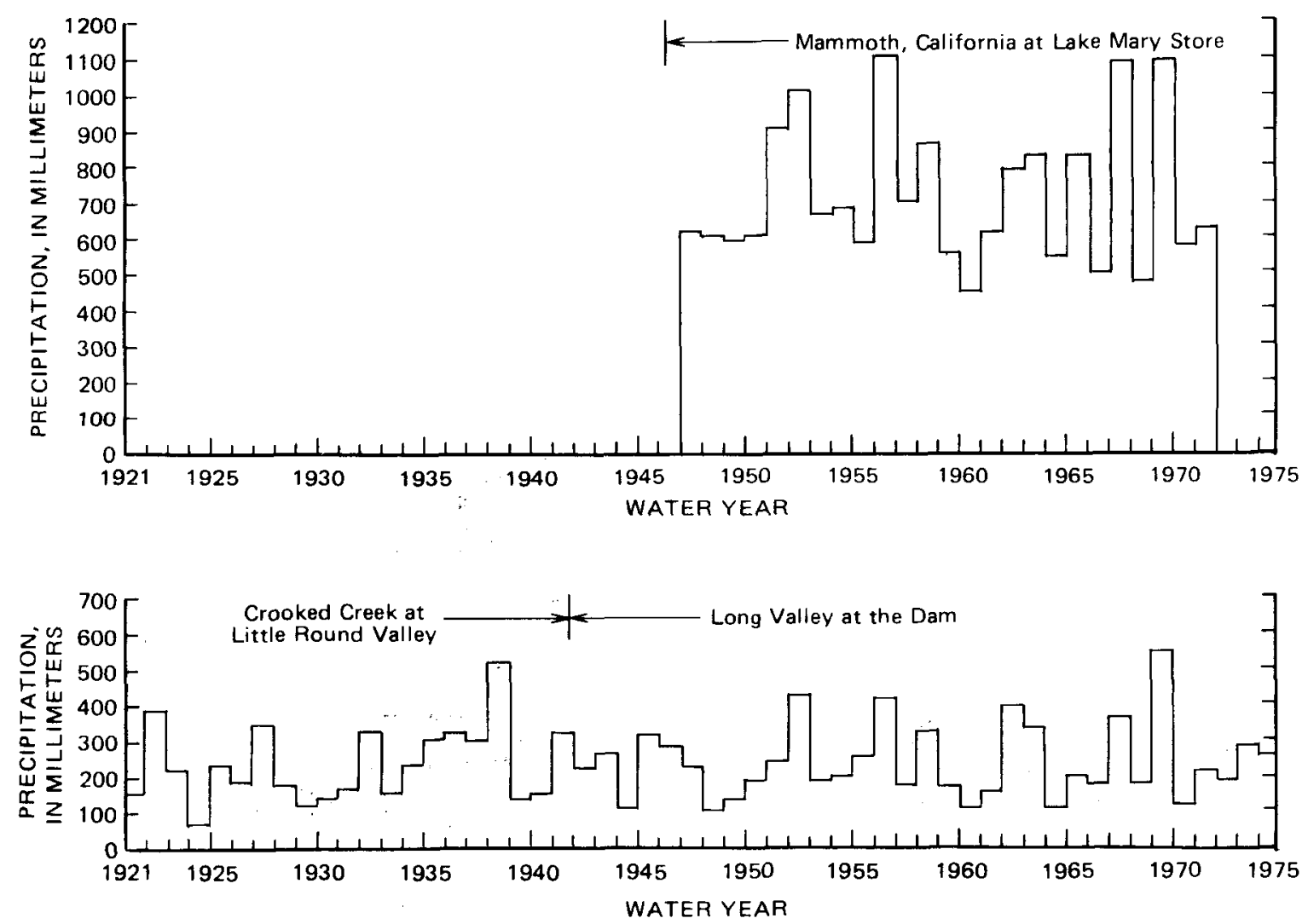

Figure 6.-Annual precipitation at Lake Mary Store and Long Valley Dam. Data from written communication, Los Angeles Department of Water and Power, 1976. 
The lack of adequate precipitation data in the Long Valley basin required the generation of additional data by an indirect method to draw figure 5 . Data presented in figure 7 indicate that precipitation is not a function of altitude alone. Spreen (1947) showed that, along with altitude, the amount of precipitation is influenced by other parameters such as slope, orientation, and exposure. On the basis of Spreen's work, we constructed a family of curves relating precipitation to these factors, using available data from along the east slope of the Sierra Nevada. With the aid of these curves, we estimated the annual precipitation for 71 data points below $3,000 \mathrm{~m}$ altitude; for altitudes above $3,000 \mathrm{~m}$, we used the annual precipitation shown by Rantz (1972). These data were contoured to produce the isohyetal map in figure 5 .

Little direct information is available concerning air temperatures within the caldera. Indirect evidence from measurements of temperature at shallow depths in test wells suggests that the average annual temperature at the land surface ranges from about $6^{\circ} \mathrm{C}$ at higher altitudes in the west-central part of the caldera

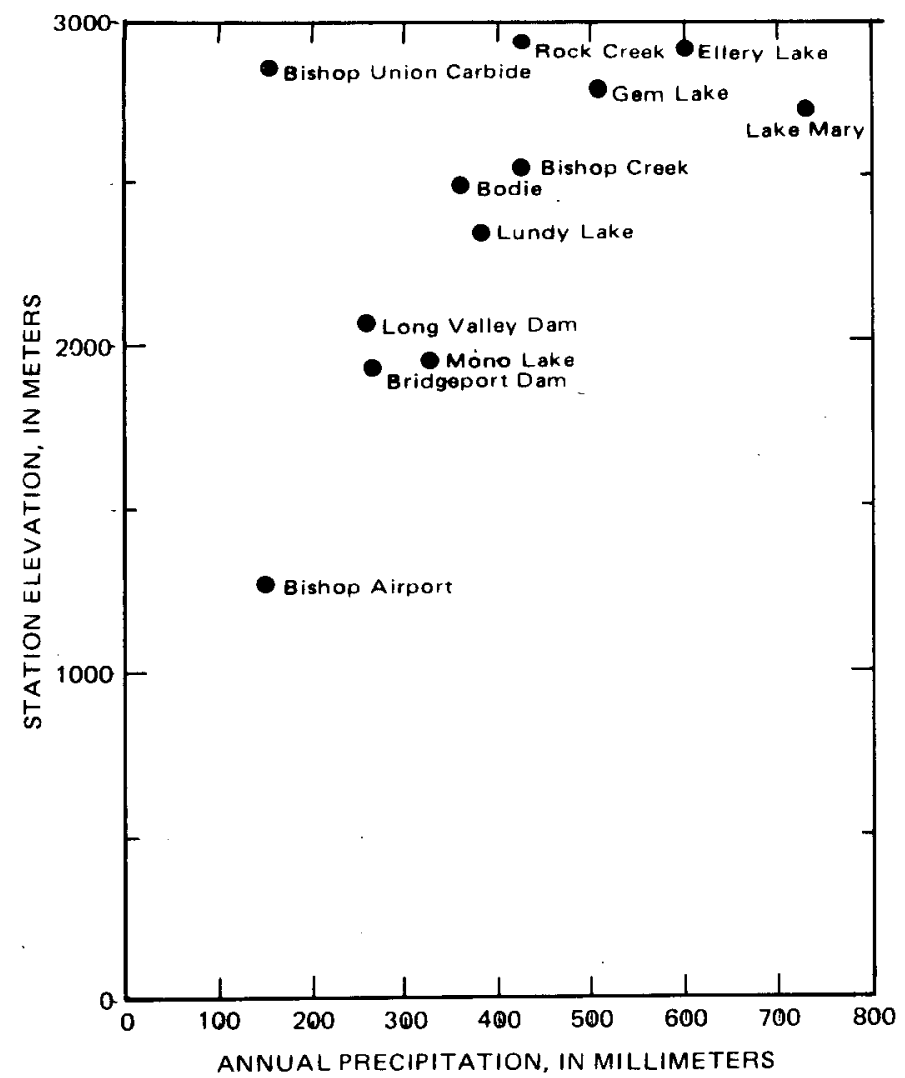

Figure 7.-Relation between precipitation and altitude at stations on the east slope of the central Sierra Nevada. Data from U.S. Weather Service climatological records, and written communication, Los Angeles Department of Water and Power, 1976. floor to perhaps $10^{\circ} \mathrm{C}$ at lower altitudes near Lake Crowley, in the southeast. In heat-flow calculations, described in a later section, we use an average value of $8^{\circ} \mathrm{C}$.

\section{WATER BUDGET}

A water budget for the Long Valley drainage basin for the water years 1964-74 is presented in table 3 . In calculating the budget, we assumed that (1) all the water in the hydrologic system originates as rain or snow and (2) inflow to the basin equals outflow. during the budget period except for change in storage in Lake Crowley. The first assumption is not valid if a significant fraction of the hot water in the hydrothermal reservoir has a magmatic source. However, the results of isotope studies of Long Valley and of similar hydrothermal systems throughout the world (White, 1968) indicates that the proportion of magmatic water in the total inflow or outflow in the basin is very small; it can be neglected in this discussion. The second assumption is valid only if the change in ground-water storage in the basin is insignificant in relation to total

TABLE 3.-Water budget for the Long Valley drainage basin for water years 1964-74

\begin{tabular}{|c|c|c|}
\hline Inflow: & $\mathrm{L} / \mathrm{s}$ & $\mathrm{hm}^{3 / \mathrm{yr}}$ \\
\hline Owens River below East Portal ${ }^{1}$ & 5,140 & 162.3 \\
\hline Hot Creek at the gorge ${ }^{2}$ & 1,810 & 57.1 \\
\hline McGee Creek & 930 & 29.4 \\
\hline Convict Creek & 805 & 25.4 \\
\hline Hilton Creek & 344 & 10.9 \\
\hline Rock Creek Diversion ${ }^{3}$ & 293 & 9.3 \\
\hline Laurel Creek ${ }^{4}$ & 168 & 5.3 \\
\hline Crooked Creek & 113 & 3.6 \\
\hline Precipitation on Lake Crowley & 168 & 5.3 \\
\hline Ungaged inflow $^{6}$ & 1,090 & 34.5 \\
\hline Total inflow (rounded) & $\overline{10,900}$ & $\overline{343.0}$ \\
\hline
\end{tabular}

Outflow:

Main venturi at Long Valley Dam

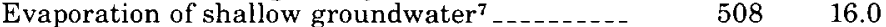

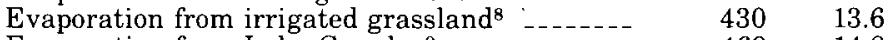

Evaporation from Lake Crowley ${ }^{9} \ldots$

Owens River gorge, Main Weir._-_-_-_ $121 \quad 3.8$

Ground-water loss to regional system

Change in reservoir storage, 1964-1974 -1100

Total outflow (rounded)

'Includes water imported from Mono Lake basin: $113.2 \mathrm{hm} / \mathrm{hr}(3,590 \mathrm{~L} / \mathrm{s})$ average for the 11-year period of record.

${ }^{2}$ Includes discharge from the Hatchery springs and hot springs in Hot Creek gorge.

'Period of record: 1966-1974 water years.

${ }^{4}$ Period of record: 7/70-7/73, from Calif. DWR (1973).

${ }^{5}$ Average $25 \mathrm{~mm}$ on $21 \mathrm{~km}^{2}$ of lake surface.

${ }^{6}$ Includes recoverable water from ungaged drainage and all spring discharge except as described in ${ }^{2}$ above.

${ }^{7}$ From $85 \mathrm{~km}^{2}$ area where water table is less than $2.4 \mathrm{~m}$.

"Same as from a lake- $690 \mathrm{~mm} ; 19 \mathrm{~km}^{2}$ irrigated.

"Average $690 \mathrm{~mm}$ from $21 \mathrm{~km}^{2}$ lake surface. 
inflow or outflow during the budget period. Although specific data for the budget period are lacking, we believe this condition to be reasonably well fulfilled. On the basis of observed changes in water level in shallow test holes during 1972-74, a change of $1 \mathrm{~m}$ in average water level throughout the caldera floor from the beginning of 1964 water year to the end of water year 1974 should be an upper limit. Assuming water-table (unconfined) conditions and an average storage coefficient of 0.3 , a $1-\mathrm{m}$ change in water level over the 450 $\mathrm{km}^{2}$ of the caldera floor would amount to $135 \mathrm{hm}^{3}$-less than 4 percent of the estimated total inflow or outflow of about $3,800 \mathrm{hm}^{3}$ to the drainage basin during the 11-year budget period.

The inflow items in the budget (table 3 ) include streamflow measured at eight gaging stations, an estimate of streamflow from several ungaged areas, and precipitation on Lake Crowley. Except for the precipitation directly on Lake Crowley, the annual volume of precipitation in the basin was not estimated as a discrete budget item. Instead, the fraction of the precipitation that runs off in the stream channels is measured at the eight gaging stations shown in plate 1 and figure 8. A part of the measured flow is direct runoff after storms or from melting snow, but the remainder is base runoff furnished by ground-water discharge into the stream channels above the gaging stations. In this section of the report we do not estimate either the amount of base runoff or the proportions of the base runoff that are supplied from the deep hydrothermal reservoir (deep subsystem) and from the shallow nonthermal ground-water reservoir (shallow subsystem). Instead, we include estimates of the discharge from the hydrothermal reservoir in later parts of the report.

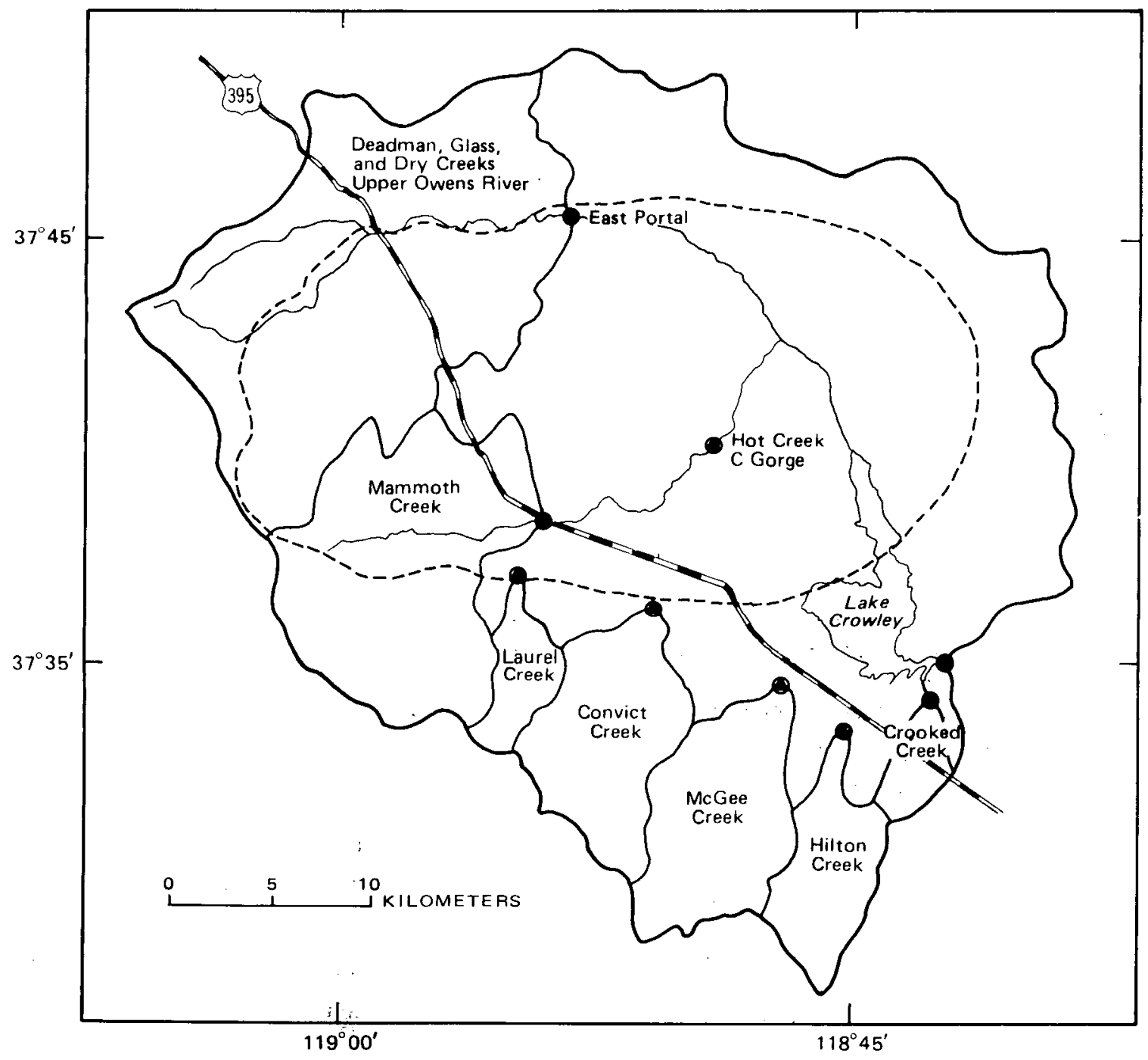

FIGURE 8.-Map showing tributary drainage areas and streamflow-measuring stations in the Long Valley basin. 
Ground-water underflow into Lake Crowley is not included as an item of inflow because hydrologic information was insufficient to determine this quantity directly. It is likely, however, that ground-water flow into the lake and into the Owens River below the East Portal gage accounts for a significant part of the computed $11 \mathrm{hm}^{3} / \mathrm{yr}(350 \mathrm{~L} / \mathrm{s})$ difference between total inflow and outflow. In the section, "Thermal characteristics of the hydrothermal system," we estimate a discharge of $4.8 \mathrm{hm}^{3} / \mathrm{yr}(120 \mathrm{~L} / \mathrm{s})$ of warm ground water $\left(50^{\circ} \mathrm{C}\right)$ southeastward across the caldera boundary into southwestern Lake Crowley.

Most streamflow originates in the Sierra Nevada along the west and south margins of the basin, where precipitation exceeds potential evapotranspiration and where snowpacks last into the late spring in most years. Seven Sierra streams are measured by the Los Angeles Department of Water and Power.

Approximately 30 percent of the measured runoff from the Sierra Nevada originates in the northwest part of the basin drained by Deadman, Dry, and Glass creeks. In the discussion below, this part of the basin is called the upper Owens River area. The flow from these three Owens River tributaries is not measured directly but is calculated from the difference measured at the gages at Owens River below East Portal and at the East Portal of the Mono Tunnel. The average discharge from this drainage area is about $49.1 \mathrm{hm}^{3} / \mathrm{yr}(1,560 \mathrm{~L} / \mathrm{s})$. Mammoth, Convict, and McGee creeks contribute more than half of the measured runoff to the basin from the Sierra Nevada or about $77.7 \mathrm{hm}^{3} / \mathrm{yr}(2,460 \mathrm{~L} / \mathrm{s})$. The remainder of the runoff from three small Sierra Nevada tributaries amounts to only about 14 percent of the measured total.

Additional runoff, not measured, is generated from about $44 \mathrm{~km}^{2}$ along the lower slope of the Sierra Nevada south of the caldera and from about $127 \mathrm{~km}^{2}$ between Bald Mountain and Glass Mountain Ridge north of the caldera and around to Long Valley Dam on the east. Additional runoff, also ungaged, occurs from $55 \mathrm{~km}^{2}$ of the resurgent dome.

To estimate the quantity of water entering the basin as ungaged runoff, the relation between average annual precipitation and average annual runoff, shown in figure 9 , was used. The area-weighted mean annual precipitation for each of the gaged Sierra Nevada tributary basins was obtained from figures 5 and 8 , and plotted versus the average annual runoff measured for the corresponding basin. To construct the curve, water losses from runoff above the gaging stations. were assumed to be negligible and measured flows were used to represent recoverable water in the water-budget computations. The curve is constrained at the left by our assumption, based on the work of Blaney (1933) and others, that runoff is near zero where annual precipitation is less than $250 \mathrm{~mm}$. Estimates of annual runoff (recoverable water) from all the ungaged areas in the Long Valley drainage were computed using figures 5 and 9 and are summarized in table 4 . The total estimated runoff from the ungaged areas is 34.5 $\mathrm{hm}^{3} / \mathrm{yr}(1,090 \mathrm{~L} / \mathrm{s})$.

On the basis of the curve shown in figure 9, data points for the upper Owens River, Mammoth Creek, and Laurel creek are anomalous. This could be caused by precipitation values which are too high or by runoff which was not measured. Precipitation values for the Mammoth Creek drainage basin are from two precipitation gages and five snow courses and afford better control for that basin than for any of the other drainage basins. The relations for the adjacent upper Owens River and Laurel Creek drainage basins also benefit, to a lesser extent, from these data. Thus, if the precipitation-runoff relation in figure 9 is valid, a loss of runoff by downward percolation is indicated for the Mammoth Creek, Laurel Creek, and upper Owens River drainage basins. If the data point for Mammoth Creek is shifted laterally to intersect the curve in figure 9 , an increased runoff of about $170 \mathrm{~mm}$ or 18.9

TABLE 4.-Estimated runoff from ungaged areas in the Long Valley drainage basin

\begin{tabular}{|c|c|c|c|c|c|}
\hline \multirow[b]{2}{*}{ Drainage } & \multirow{2}{*}{$\begin{array}{l}\text { Area } \\
\left(\mathrm{km}^{2}\right)\end{array}$} & \multirow{2}{*}{$\begin{array}{l}\text { Precip- } \\
\text { itation } \\
(\mathrm{mm})\end{array}$} & \multicolumn{3}{|c|}{ Average annual runoff } \\
\hline & & & $(\mathrm{mm})$ & $(\mathrm{L} / \mathrm{s})$ & $\left(\mathrm{hm}^{3} / \mathrm{yr}\right)$ \\
\hline Bald Mtn-Glass Mountain Ridge & 81.1 & 670 & 190 & 485 & 15.30 \\
\hline Resurgent Dome & 55.2 & 530 & 110 & 188 & 5.92 \\
\hline Sierra Nevada: & & & & & \\
\hline Ungaged 1 & 3.4 & 510 & 94 & 10 & .32 \\
\hline Ungaged $2_{-}$ & 7.3 & 560 & 120 & 28 & .89 \\
\hline Valley Floor & 215.0 & 360 & 31 & 207 & 6.54 \\
\hline Total or average (rounded) & $\overline{442.0}$ & 460 & 78 & $\overline{1,090}$ & 34.5 \\
\hline
\end{tabular}


$\mathrm{hm}^{3} / \mathrm{yr}(600 \mathrm{~L} / \mathrm{s})$ is indicated. Similarly, for Laurel Creek the increase in runoff is $66 \mathrm{~mm}$ or $0.99 \mathrm{hm}^{3} / \mathrm{yr}$ $(31 \mathrm{~L} / \mathrm{s})$, and for the upper Owens River it is $56 \mathrm{~mm}$ or $10.6 \mathrm{hm}^{3} / \mathrm{yr}(336 \mathrm{~L} / \mathrm{s})$.

Most of the water lost above the gaging stations on Mammoth and Laurel Creeks probably migrates downward through fractures in the shallow Mammoth Lakes basalts described by Bailey (1974) and, along with other shallow ground water and possibly a small amount of hot water (Sorey, 1975b), furnishes most of the $30.4 \mathrm{hm}^{3} / \mathrm{yr}(964 \mathrm{~L} / \mathrm{s})$ discharge in the springs at the Hot Creek Fish Hatchery. Test drilling shows that basalts in the upper Owens River drainage area are also fractured, and temperature profiles in heat-flow holes indicate downward movement of cold water to depths of at least $200 \mathrm{~m}$ around the northwest periphery of the caldera, as discussed in a later part of this report. Thus, the indicated $10.7 \mathrm{hm}^{3} / \mathrm{yr}(336 \mathrm{~L} / \mathrm{s})$ of water lost in the upper Owens River drainage basin is a possible source of recharge to the deep hydrothermal system, from which a discharge of $200-300 \mathrm{~kg} / \mathrm{s}$ is estimated (see section, "Chemical Geothermometers").

All this additional water amounts to about 30.5 $\mathrm{hm}^{3} / \mathrm{yr}(965 \mathrm{~L} / \mathrm{s})$ but is not included as a separate item in the hydrologic budget. Instead, the flows from the Hatchery springs and the Hot Creek gorge springs, which include most of the hot spring discharge in the caldera, are included in the measured flow of Hot

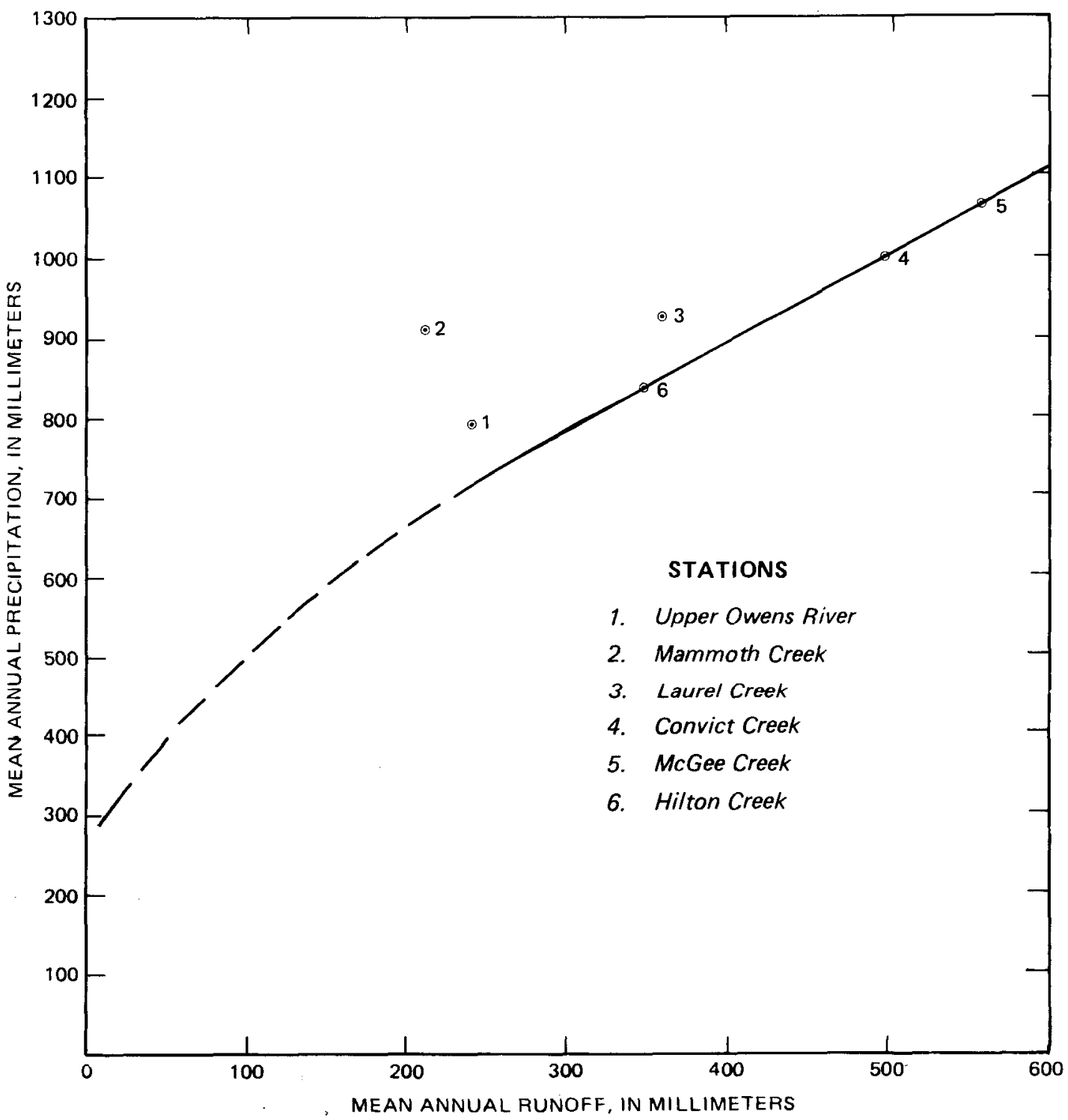

FIGURE 9.-Relation between precipitation and runoff for streams within Long Valley drainage basin. 
Creek at the downstream end of the gorge. On plate 1, the springs in Hot Creek gorge are in T3S/R28E-S25, along a $1.5-\mathrm{km}$ reach of Hot Creek bounded by the NW-SE trending graben faults.

Since 1947 , about $69.9 \mathrm{hm}^{3} / \mathrm{yr}(2,220 \mathrm{~L} / \mathrm{s})$ of water has been imported annually from Mono Lake basin north of Long Valley. During water years 1964-74, imported water from the Mono Lake basin averaged 113 $\mathrm{hm}^{3} / \mathrm{yr}(3,590 \mathrm{~L} / \mathrm{s})$. The imported water enters the Long Valley drainage basin through the Mono Craters Tunnel, flows into the Owens River at East Portal and then to Lake Crowley where it is stored, and subsequently is released at Long Valley Dam to regulate the flow in the Los Angeles Aqueduct. Since 1965, an additional 9.3 $\mathrm{hm}^{3} / \mathrm{yr}(293 \mathrm{~L} / \mathrm{s})$ has been diverted into the Long Valley system from the Rock Creek drainage basin adjacent to the Long Valley basin on the southeast.

Most discharge from the Long Valley drainage basin consists of controlled releases from Lake Crowley. The releases are measured with a Venturi meter by the Los Angeles Department of Water and Power. Since the completion of Long Valley Dam in 1941, about 205 $\mathrm{hm}^{3} / \mathrm{yr}(6,490 \mathrm{~L} / \mathrm{s})$ has been discharged from the basin. During water years 1964-74, the discharge averaged about $306 \mathrm{hm}^{3} / \mathrm{yr}(9,690 \mathrm{~L} / \mathrm{s})$. The increase in outflow for the modern 11-year base period is due to the increase in the volume of water imported from the Mono Lake basin. An additional $3.8 \mathrm{hm}^{3} / \mathrm{yr}(121 \mathrm{~L} / \mathrm{s})$ was released through the main weir at the dam.

Natural discharge of ground water occurs as evaporation from soil where the water table is near the surface and as transpiration from native vegetation. The estimate in table 3 of $16.0 \mathrm{hm}^{3} / \mathrm{yr}(508 \mathrm{~L} / \mathrm{s})$ of evaporation of shallow ground water was based on the work of White (1932), Houk (1951), and McDonald and Hughes (1968). Transpiration of ground water by phreatophytes was neglected except for the $13.6 \mathrm{hm}^{3} / \mathrm{yr}$ $(430 \mathrm{~L} / \mathrm{s})$ attributable to areas of saltgrass (Distichlis spicata) cover along the Owens River and between $\mathrm{Al}$ kali Lakes and Lake Crowley where the water table is less than $1 \mathrm{~m}$ below land surface.

An investigation along an $11-\mathrm{km}$ reach of the Owens River gorge below Long Valley Dam showed no springs or seeps which might indicate subsurface outflow of water from the Long Valley drainage basin. However, in the modeling study described in the section, "Analysis of Conceptual Model of Hydrothermal System," a ground-water discharge of $3.47 \mathrm{hm}^{3} / \mathrm{yr}(110 \mathrm{~L} / \mathrm{s})$ from the deep ground-water subsystem (the hydrothermal reservoir), through the southeast rim of the caldera, is included. This provides an outlet for the flux of relatively cool ground water which is indicated by the temperature profile in the Republic Geothermal, Inc. test well to be moving through the Bishop Tuff under the southeastern part of the caldera.

Some natural discharge occurs from the lake surface and from springs, pools, and streams as evaporation. The evaporative loss of water is measured at one station near the dam by the Los Angeles Department of Water and Power. The long-term average annual pan evaporation losses measured at the dam are about $1,000 \mathrm{~mm}$. Using a pan coefficient of 0.7 , this converts to an equivalent lake evaporation of about $700 \mathrm{~mm}$. For a lake the size of Lake Crowley, this amounts to an average evaporation of about $14.8 \mathrm{hm}^{3} / \mathrm{yr}(469 \mathrm{~L} / \mathrm{s})$.

At the end of water year $1974,31.2 \mathrm{hm}^{3}$ more water was stored in Lake Crowley than at the beginning of water year 1964, the start of the 11-year budget period. This amounts to an average annual increase of 2.84 $\mathrm{hm}^{3}$, which is shown in table 3 as a negative outflow item.

As shown in table 3 , the total average annual outflow of $354 \mathrm{hm}^{3}$ exceeds the total average annual inflow of $343 \mathrm{hm}^{3}$ by only about 3.2 percent, which indicates fairly good agreement. Although the largest items of both inflow and outflow are streamflows measured by standard techniques for which errors of less than 5 percent of flows for periods of several years are to be expected, some of the estimated items are sizable fractions of the totals. Large errors in these estimates seem to be precluded by the fairly small imbalance in total outflow and inflow. Furthermore, as discussed previously, part or all of the $11 \mathrm{hm}^{3} / \mathrm{yr}$ imbalance could be attributed to unmeasured ground-water underflow in Lake Crowley.

\section{SHALLOW AND DEEP GROUND.WATER SUBSYSTEMS}

For purposes of the present analysis, it is useful to consider the ground-water system in the Long Valley caldera as comprising two major parts: (1) a shallow subsystem in which temperatures are not much higher than ambient land-surface temperatures, groundwater flow paths are relatively short and direct from areas of recharge to areas of discharge, and, except where increased locally by evapotranspiration in the areas of shallow water table, the concentrations of dissolved solids are relatively low; and (2) a deep subsystem in which temperatures are commonly much higher than ambient surface temperatures, ground-water flow paths are relatively long and circuitous, and concentrations of dissolved solids-especially some of the alkali chlorides, silica, boron, and arsenic-are relatively high. The two parts of the system are not everywhere sharply delineated; but, in general, the shallow subsystem is contained in the fill above the densely welded Bishop Tuff. This part of the caldera fill 
consists chiefly of intercalated lava flows and tuffs in the western part and chiefly of tuffs and lacustrine and fluvial sediments in the eastern part. The lower part of the fill, which contains the deep subsystem, probably consists chiefly of densely welded Bishop Tuff with subordinate amounts of pre-Bishop Tuff volcanic and (or) metasedimentary rocks.

As described previously, the average porosity of the materials of the shallow subsystem probably is much greater than that of the underlying densely welded Bishop Tuff of the deep subsystem. Although the shallow materials include some volcanic flows of low porosity, especially in the west part of the caldera, the intergranular porosity of the tuffs and sediments is high (see table 6). By contrast, the intergranular porosity of the Bishop Tuff in the caldera is very low, and most of the pore space, which probably averages less than 10 percent of the total volume, is in secondary fractures associated with contraction of the rock on cooling or with deformation.

Ground water in the shallow subsystem circulates through the relatively coarse-grained, more permeable sediments and, locally, through brecciated or faulted zones in the volcanic flows. Much of the material, however, is clayey, tuffaceous, or altered sedimentary deposits or dense flows of extremely low permeability (see table 6). Such material forms confining layers which separate aquifers in the shallow subsystem and, more significantly, probably separate the shallow and deep subsystems from each other except locally where high-angle normal faults provide interconnecting channelways for upward- or downward-flowing ground water. Places where flow is assumed to occur vetween the shallow and deep subsystems are described later in the section, "Analysis of Conceptual Model of $\mathrm{Hy}$ drothermal System."

Table 5.-Laboratory data for selected cores from test holes in Long Valley caldera [Sample analyses run by Hydrologic Laboratory, WRD, Denver, Colo., except as noted below]

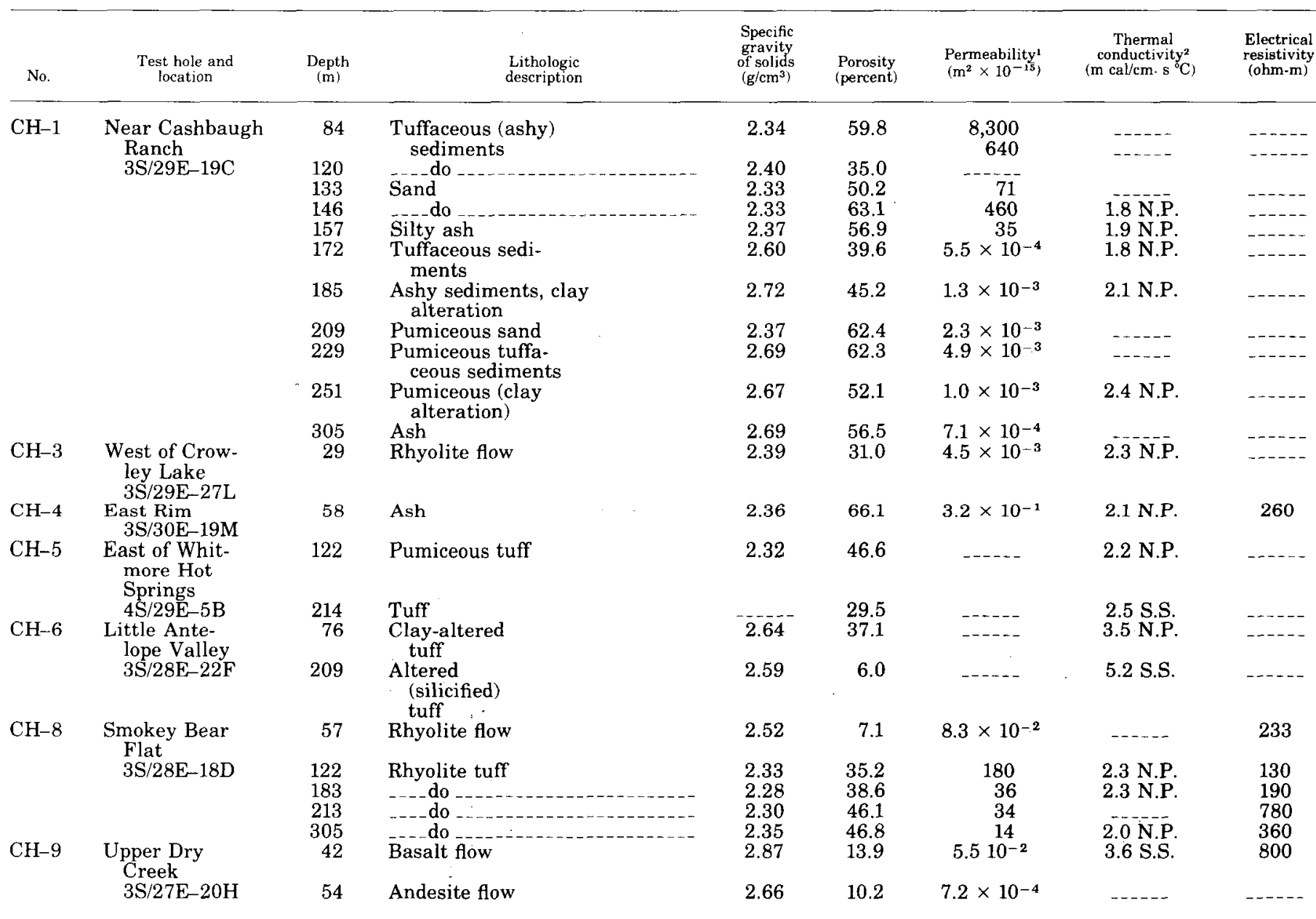

${ }^{1}$ Computed from vertical hydraulic conductivity measurement run with water matching chemical composition of appropriate ground water, at temperature of $16^{\circ} \mathrm{C}$

${ }^{2}$ N.P. signifies needle probe measurement; data for CH-1, 4, 5, 6, $8(183 \mathrm{~m})$ run in Heat Flow Laboratory, Geologic Division, Menlo Park, Calif. S.S. signifies divided bar, steadystate, conductivity measurements, made in Menlo Park Heat Flow Laboratory. All measurements made on water-saturated samples. 


\section{GROUND WATER IN THE SHALLOW SUBSYSTEM}

Shallow ground water in Long Valley caldera is both confined and unconfined. In the eastern two-fifths of the caldera, ground water is in unconsolidated lacustrine and alluvial deposits of gravel, sand, silt, and clay. In the western three-fifths, some shallow ground water is in similar unconsolidated deposits, but most is in lava flows and tuffs of the resurgent dome and west moat. Recharge to the shallow subsystem is derived from infiltration of precipitation and runoff from the Sierra Nevada and other surrounding mountains. Depth to water in wells and test holes in the alluvium ranges from less that $0.3 \mathrm{~m}$ to about $8 \mathrm{~m}$. In the northcentral and northeast parts of the valley, a thin (5-24 m) layer of very fine grained ash underlies the surface at depths between 2 and $27 \mathrm{~m}$. This fairly extensive ash acts as an effective confining bed. Test holes that penetrate the ash either flow or have potentiometric heads higher than those in wells in the shallow, unconfined aquifer. The exact nature and extent of the fine-ash confining bed and the underlying confined aquifer are not known from the shallow drilling. Either deeper drill holes were not in the area of the confined aquifer, or insufficient borehole data were obtained in the upper $30-50 \mathrm{~m}$ to describe it adequately. The ash contains abundant shells of ostracods and was probably deposited in the Pleistocence Long Valley Lake described by Mayo (1934). The confined aquifer immediately below the ash may consist of coarser ash or other pyroclastic deposits separated by differential settling in the lake.

Little is known about deeper aquifers in the shallow subsystem. Permeable zones were encountered in drilling each of 9 core holes to depths ranging from $52 \mathrm{~m}$ to $325 \mathrm{~m}$. For the most part, however, more data is needed to delineate the lateral extent of any individual zone. Deep circulating ground water associated with the geothermal system (the deep subsystem) is discussed later.

Water-level contours in figure 10 are based primarily on measurements made in spring 1973. The water table in most of the Long Valley caldera slopes eastward toward the Owens River and Lake Crowley. The configuration of the water table is fairly well defined in the lower, east part of the caldera, where wells and streams that intersect the water table are numerous, but is poorly defined in the west part, particularly in the resurgent-dome area. Nevertheless, the general pattern in figure 10 is believed to be substantially correct.

The most striking features are (1) the steeper hydraulic gradient in the west-the average is about 0.02 -as compared to the gradient of only 0.01 in the east, between the east edge of the resurgent dome and Owens River-upper Lake Crowley; (2) a broad zone of gentle gradient in the south-central area of the moat, where the eastward gradient is only about 0.006 ; and (3) a steep gradient north of the intersection of U.S. 395 with the south rim of the caldera-the fault (shown on pl. 1) passing through this zone appears to function as a barrier to eastward ground-water movement in the shallow sedimentary and volcanic rocks. Feature 2 reflects the topography in that area, which includes a broad, flat-lying zone, underlain by basalt flows and alluvium. The combination of a gentle hydraulic gradient and relatively large ground-water discharge in the springs at the Hot Creek Fish Hatchery implies that high permeability channels exist in the basalt or interbedded sediments in this area. This is confirmed by drillers' logs obtained for wells at Mammoth School, just west of the Hatchery. Water-table altitudes from figure 10 , in potential recharge areas around the caldera rim and in the principal hot-spring-discharge area in Hot Creek gorge (pl. 1, T. 3 S/R. 28 E.-S. 25), were used to develop constant pressure boundary conditions in the modeling study.

\section{HYDRAULIC CHARACTERISTICS OF CALDERA FILI}

As discussed previously, the rock units comprising the shallow ground-water subsystem - the caldera fill above the densely welded Bishop Tuff-include nearsurface weathered volcanic flows and tuffs in the west part and predominantly alluvial and lacustrine sediments in the east. These rocks are underlain by postcaldera rhyolites, rhyodacites, and basalts. Analyses of cores and cuttings from test holes to depths of $300 \mathrm{~m}$ indicate considerable variability in the hydraulic properties of these materials. Interpretation of hydraulic properties is further complicated by the distribution of faults which cover most of the western three-fifths of the caldera.

No flow tests or pumping tests were conducted during the drilling program. However, drilling with hydraulic- (mud-) rotary methods provided data on zones of relatively low permeability (low mud loss) and zones of relatively high permeability (high mud loss or artesian flow). In general, the test drilling showed that permeable zones were confined to volcanic flows in the west and to relatively thin sandy zones in the east. An exception was at $\mathrm{CH}-10$ near Hot Creek gorge where the fault forming the east boundary of a graben (fig. 1) was intersected at a depth of about $30 \mathrm{~m}$ and a permeable zone in altered rhyolite was encountered. The number and distribution of test holes were insufficient to describe the lateral extent of permeable zones in the 
flows in the west caldera. However, as discussed in a later section, temperature measurements made at core-hole sites east of Hot Creek gorge indicate an aquifer above $100 \mathrm{~m}$ with sufficient continuity to transmit warm water toward Lake Crowley.

Results of laboratory analyses of selected cores from the Long Valley test holes are given in table 5. In all but the flow rocks and silicified sediments, porosities are high $(>35$ percent) and thermal conductivities are low, so that the rocks of the shallow subsystem act as a thermal blanket, producing high temperatures in the underlying rocks of the deep subsystem. Vertical permeabilities measured on the cores are extremely varied, ranging from $5.5 \times 10^{-4}$ to $8.3 \times 10^{+3}$ millidarcys. The lowest values were obtained for rocks and deposits that are hydrothermally altered to varying degrees. Such altered materials were penetrated in core holes within the present area of hot-spring activity and on the resurgent dome in Little Antelope Valley. The occurrences of altered deposits suggest that upward movement of hot water from the deep subsystem is restricted to zones where recent fault movements provide conduits through the capping rocks of the shallow system.

Hydrothermal alteration is much less widespread in the west part of the caldera than in the east part. Active fumaroles and zones of acid alteration occur on Mammoth Mountain and at Casa Diablo Hot Springs, and a zone of hydrothermal alteration parallels the southwest caldera wall near the base of Mammoth Mountain (Bailey and others, 1976). Pyritized rhyolite was found at a depth of $210 \mathrm{~m}$ in drill hole DC in the northwest moat. However, no evidence of alteration was found in $\mathrm{CH}_{-} 8$ (325 m deep) in Smokey Bear Flat

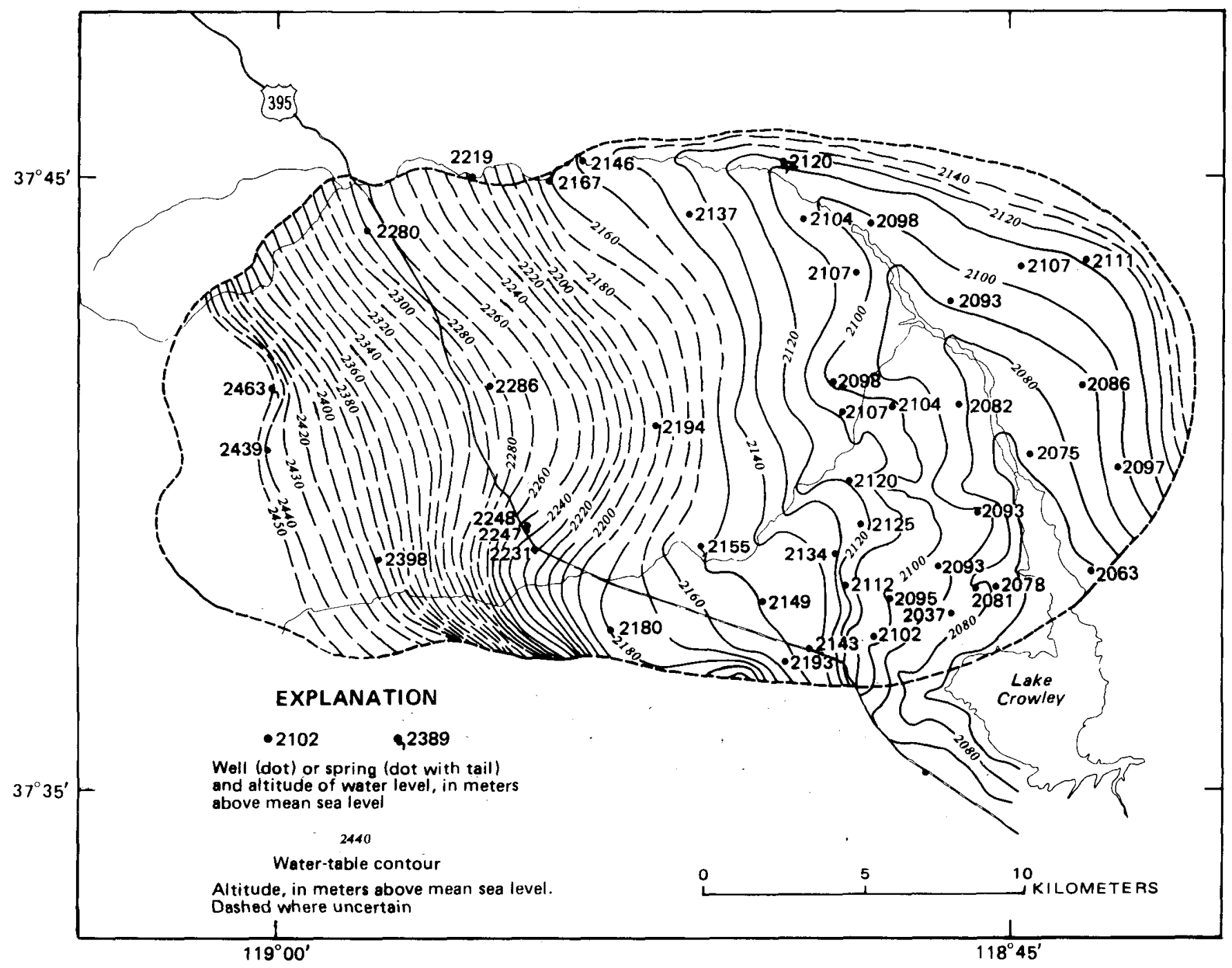

FIGURE 10.--Map of Long Valley caldera showing configuration of the water table, spring 1973. Data from Lewis, 1974. Contour interval 20 m. 
and $\mathrm{CH}-9$ (92 $\mathrm{m}$ deep) in the upper Dry Creek drainage basin. Permeable zones in the shallow ground-water subsystem in the west appear to be restricted to channels in the flow rocks, resulting from some combination of fractures, cooling joints, and brecciated surfaces. Large lateral flows of cold water in these layers also appear to be responsible for the isothermal nature of the temperature profiles in core holes $\mathrm{CH}-8, \mathrm{CH}-9$, and DC, where significant recharge from the surface through more than $35 \mathrm{~m}$ of unsaturated materials appears to be unlikely.

Secondary permeability caused by recent faulting may be hydraulically effective only in the more competent rocks, such as the welded Bishop Tuff and preTertiary basement rocks, and apparently sediments which have undergone alteration (silicification and zeolitization). Drilling data and lab tests on cores indicate that the primary permeability of the postcaldera tuffs and altered sediments and the unfractured flow rocks is relatively low. Therefore, in our conceptual model of the hydrothermal system, the fractured, welded Bishop Tuff and the underlying basement rocks are assumed to provide the hot-water reservoir. If this is correct, these rocks should also be altered, and maintenance of permeable flow channels may have required either or both continued tectonic activity or successive invasion of unaltered rock by hydrothermal fluids. Ground-water flow in the overlying shallow subsystem is neglected except in recharge areas around the caldera rim and in the hot-spring discharge area. Secondary effects, such as mixing of shallow ground water with upflowing hot water and'shallow subsurface discharge of hot water are discussed in a later section. These effects were not included in numerical simulations with the model.

\section{GEOCHEMICAL CHARACTERISTICS OF THE HYDROTHERMAL SYSTEM}

\section{CHEMICAL PATTERNS}

Surface and ground waters of Long Valley have distinct differences in chemical composition. In large part, the variations in chemical character reflect sharp differences between deep hot waters and shallow cold waters, and they also indicate the local proportions of these two contrasting types. The California Department of Water Resources (1967) has identified four principal types of water on the basis of proportions of major dissolved constituents and concentration of dissolved solids: (1) cold surface and ground waters along the caldera margins in which $\mathrm{Ca}$ and $\mathrm{HCO}_{3}$ are the predominant constituents and the concentration of dissolved solids is relatively low-usually $30-100 \mathrm{mg} / \mathrm{L}$;
(2) thermal waters in hot springs in which $\mathrm{Na}, \mathrm{HCO}_{3}$, and often also $\mathrm{Cl}$ are predominant and the concentration of dissolved solids is moderate-usually about $1,000-4,000 \mathrm{mg} / \mathrm{L}$; (3) alkali lakes and adjacent ground waters in the east-central caldera, where the water table is near the surface, in which $\mathrm{Na}$ and $\mathrm{HCO}_{3}$ or $\mathrm{CO}_{3}$ are predominant and concentration of dissolved solids is relatively high-about $30,000 \mathrm{mg} / \mathrm{L}$; and (4) warm springs and related shallow ground waters that represent mixtures of (1) and (2).

Except for type 3 above-a water that results from concentration of other waters by evaporation and transpiration-the types described above are useful is assessing the changes in water chemistry that result as hot geothermal fluid (type 2) mixes with cold, shallow ground water (type 1).

In addition, concentrations of $\mathrm{B}$ and $\mathrm{Cl}$ may be used to estimate the degree of mixing of hot and cold ground waters (Sorey and Lewis, 1976; Mariner and Willey, 1976). Concentrations of $B$ range from less than 0.5 $\mathrm{mg} / \mathrm{L}$ in waters from springs and wells where temperatures are $10^{\circ} \mathrm{C}$ or less to $14 \mathrm{mg} / \mathrm{L}$ in waters from hot springs and geothermal test wells (table 6 ). Concentrations of chloride in the same waters range from less than $5 \mathrm{mg} / \mathrm{L}$ to $280 \mathrm{mg} / \mathrm{L}$. Molal ratios of $\mathrm{Cl} / \mathrm{B}$ are $5.8 \pm$ 0.2 for most thermal-spring waters, which probably indicates a common source at depth. The origin of $B$ and $\mathrm{Cl}$ in the hydrothermal waters have been attributed in part to magmatic fluid rising from a magma chamber (California Department of Water Resources, 1967, p. 21). However, we believe that, although a magmatic contribution to circulating meteoric water cannot be ruled out, its proportion must be low because of the meteoric nature of the $\mathrm{D}$ and ${ }^{18} \mathrm{O}$ content of the hotspring waters. Calculations of rock volumes required for leaching of $B$, presented later, indicate that a magmatic contribution is not required to supply the observed discharge of $B$.

\section{CHEMICAL GEOTHERMOMETERS}

Results of applying the silica geothermometer of Fournier and Rowe (1966) and the Na-K-Ca geothermometer of Fournier and Truesdell (1973) to estimate the temperatures of reservoir(s) feeding the hot springs and wells in Long Valley, are given in table 7. Except for the Hot Bubbling Pool, which cools significantly by evaporation, reservoir temperatures based on the cation geothermometer exceed those based on silica. This indicates that the hot-spring waters are mixtures of hot and cold components which have not reequilibrated after mixing because the cation geothermometer, being based on ratios of constituents, is less sensitive than the silica geothermometer to changes in absolute concentration. 
TABLE 6. Selected chemical constituents, temperatures, and isotopic compositions for thermal and non thermal waters from Long Valley

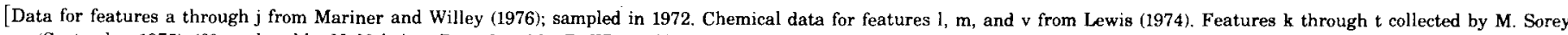
(September 1975 ), ${ }^{18} 0$ analyzed by N. Nehring, D analyzed by D. White, Cl analyzed by L. Tanner. Features u through $\mathrm{z}$ collected by B. Evans (June, 1976), D analyzed by D. White. Chemical concentrations are in milligrams per liter]

\begin{tabular}{|c|c|c|c|c|c|c|c|c|c|c|c|c|}
\hline & Location & Locality & $\mathrm{SiO}_{2}$ & $\mathrm{Na}$ & $\mathrm{K}$ & $\mathrm{Ca}$ & ${ }^{1} \mathrm{HCO}_{3}$ & $\mathrm{Cl}$ & B & $\begin{array}{l}\text { T. } \\
\text { surf. } \\
{ }^{\left({ }^{\circ} \mathrm{C}\right)}\end{array}$ & $\delta \mathrm{D}$ & $\delta^{18} \mathrm{O}$ \\
\hline a. & $3 \mathrm{~S} / 28 \mathrm{E}-13 \mathrm{ES} 3$ & Little Hot Creek & 110 & 410 & 30.0 & 50.0 & 736 & 200 & 10.6 & 79 & -121.8 & -15.84 \\
\hline c. & $3 \mathrm{~S} / 28 \mathrm{E}-35 \mathrm{ES} 1$ & Hot Bubbling Pool & 300 & 380 & 25.0 & 3.3 & 467 & 250 & 13.0 & 60 & -111.0 & -12.44 \\
\hline d. & $3 \mathrm{~S} / 29 \mathrm{E}-21 \mathrm{PS} 1$ & Big Alkali Lake & 250 & 310 & 37.0 & 25.0 & 829 & 150 & 7.7 & 56 & -123.9 & -16.17 \\
\hline e. & $3 \mathrm{~S} / 29 \mathrm{E}-28 \mathrm{HS} 1$ & S.E. of Big Alkali Lake & 240 & 400 & 43.0 & 22.0 & 846 & 170 & 8.6 & 49 & -123.4 & -15.85 \\
\hline f. & $3 \mathrm{~S} / 29 \mathrm{E}-31 \mathrm{AS} 1$ & N. of Whitmore Hot Springs & 150 & 310 & 22.0 & 15.0 & 520 & 170 & 8.1 & 58 & -121.2 & -15.23 \\
\hline j. & $3 \mathrm{~S} / 29 \mathrm{E}-13 \mathrm{C} 1$ & Well near N.E. rim & 64 & 28 & 1.3 & 5.3 & 117 & 3 & 0.2 & 10 & -129.5 & -17.07 \\
\hline $\mathrm{k}$. & $4 \mathrm{~S} / 29 \mathrm{E}-6 \mathrm{P}$ & S. of Whitmore Hot Springs & - & - & - & - & - & $<10$ & - & 16 & -120.3 & -15.26 \\
\hline 1. & $4 \mathrm{~S} / 28 \mathrm{E}-9 \mathrm{FS} 1$ & E. of Laurel Canyon & - & 5 & 1.0 & 16.0 & 46 & 1 & 0.0 & 12 & -127.7 & -16.68 \\
\hline m. & $3 \mathrm{~S} / 28 \mathrm{E}-35 \mathrm{KS} 1$ & Fish Hatchery & 33 & 15 & 3.0 & 13.0 & 95 & 3 & 0.1 & 13 & -121.0 & -15.89 \\
\hline n. & $2 \mathrm{~S} / 28 \mathrm{E}-14 \mathrm{M}$ & McLaughlin Creek & - & - & - & - & - & $<10$ & - & 8 & -130.0 & -16.87 \\
\hline 0 . & $2 \mathrm{~S} / 27 \mathrm{E}-27 \mathrm{~B}$ & Deadman Creek at 395 & - & - & - & - & - & $<10$ & - & 13 & -124.4 & -16.01 \\
\hline p. & $3 \mathrm{~S} / 27 \mathrm{E}-7 \mathrm{P}$ & Deadman Tributary & - & -- & - & - & - & $<10$ & - & 7 & -111.8 & -14.71 \\
\hline w. & $4 \mathrm{~S} / 28 \mathrm{E}-22 \mathrm{P}$ & Spring above Convict Lake & - & - & - & - & - & - & - & 13 & -125.3 & - \\
\hline $\mathrm{x}$. & $3 \mathrm{~S} / 29 \mathrm{E}-2 \mathrm{~A}$ & Well near N.E. rim & - & - & - & - & - & - & - & 14 & -129.2 & - \\
\hline y. & $3 \mathrm{~S} / 30 \mathrm{E}-5 \mathrm{~J}$ & Wilfred Creek & - & - & - & - & - & - & - & 13 & -129.2 & - \\
\hline z. & $2 \mathrm{~S} / 29 \mathrm{E}-31$ & Well E. of Arcularius Ranch & - & - & - & - & - & - & - & 10 & -134.0 & - \\
\hline
\end{tabular}

'Total alkalinity calculated as $\mathrm{HCO}_{3}$.

${ }^{2}$ Average value for 12 samples from Mariner and Willey (1976) and CDWR (1967).

${ }^{3}$ Corresponds with sample 3S/28E-25AS4 in Mariner and Willey $(1976$, p. 794), which is incorrectly located.

Applications of mixing models to estimate mixing ratios and the temperature of the hot-water component at depth have been made by Mariner and Willey (1976), Sorey and Lewis (1976), and Fournier, Sorey, Mariner, and Truesdell (1976). Reservoir temperatures estimated from the silica mixing model of Fournier and Truesdell and the silica-chloride mixing model developed by A. H. Truesdell (Sorey and Lewis, 1976) range from $200^{\circ} \mathrm{C}$ to $225^{\circ} \mathrm{C}$ and average $210^{\circ} \mathrm{C}$. These models suggested that a single reservoir with water similar to that obtained from the Casa Diablo well (that is, $219^{\circ} \mathrm{C}$,

TABLE 7.-Temperatures of reservoirs feeding hot springs in Long Valley estimated by chemical geothermometers

\begin{tabular}{|c|c|c|}
\hline Spring or well & $\begin{array}{l}\left.{ }^{1} \mathrm{TSSO}{ }^{\circ} \mathrm{C}\right)_{2} \\
\left.{ }^{\circ} \mathrm{C}\right)\end{array}$ & $\begin{array}{l}{ }^{2} \mathrm{TNa}-\mathrm{K}-\mathrm{Ca} \\
\therefore\left({ }^{\circ} \mathrm{C}\right)-\end{array}$ \\
\hline a. Little Hot Creek Spring & 143 & 172 \\
\hline b. Casa Diablo Well & 219 & 3238 \\
\hline c. Hot Bubbling Pool & 209 & 4189 \\
\hline d. $3 \mathrm{~S} / 29 \mathrm{E}-21 \mathrm{PSI}$ & 196 & 200 \\
\hline e. $3 \mathrm{~S} / 29 \mathrm{E}-28 \mathrm{HSI}$ & 193 & 200 \\
\hline f. $3 \mathrm{~S} / 29 \mathrm{E}-31 \mathrm{ASI}$ & .161 & 176 \\
\hline g. $3 \mathrm{~S} / 29 \mathrm{E}-34 \mathrm{KSI}$ & 182 & 184 \\
\hline h. Hot Creek Gorge Spring & 153 & 192 \\
\hline
\end{tabular}

${ }^{1}$ By the method of Fournier and Rowe $(1966)$.

'By the method of Fournier and Truesdell (1973

"Affected by calcite deposition.
$14 \mathrm{mg} / \mathrm{L} \mathrm{B}, 280 \mathrm{mg} / \mathrm{L} \mathrm{Cl}$ ) underlies or at least feeds all the major hot springs in the caldera.

A more recent anyalysis of the geothermometer and isotope data by Fournier, Sorey, and Mariner (1976) using chloride-enthalpy relations suggests a somewhat more complicated circulation system, including a deep aquifer with water at $282^{\circ} \mathrm{C}, 375 \mathrm{mg} / \mathrm{L} \mathrm{Cl}$, and 18.8 $\mathrm{mg} / \mathrm{L} \mathrm{B}$. This water could yield the $219^{\circ} \mathrm{C}$ Casa Diablo water bs mixing with cold water, and the $201^{\circ} \mathrm{C}$ Hot Creek gorge water by boiling and steam loss. Oxygen and deuterium isotopic data, as discussed later, are consistent with this interpretation, as are reservoir temperature estimates of $269^{\circ} \mathrm{C}-273^{\circ} \mathrm{C}$ based on oxygen-isotope composition of dissolved sulfate in thermal waters (McKenzie and Truesdell, 1977; Fournier and others, 1976).

Sorey and Lewis (1976) compared the concentrations of $\mathrm{B}$ and $\mathrm{Cl}$ in each of the major thermal springs with those in the sample from the Casa Diablo well to calculate the hot-water component in the measured spring flows. A total hot-water discharge of $250 \mathrm{~L} / \mathrm{s}$ was obtained, of which approximately 80 percent is contributed by the springs in the Hot Creek gorge. This estimate is based on discharge measurements at relatively warm surface temperatures and should be corrected for hot-water density and temperature to yield a mass flux 
of $250 \mathrm{~kg} / \mathrm{s}$ and a volumetric flux of $290 \mathrm{~L} / \mathrm{s}$ at $210^{\circ} \mathrm{C}$. Fournier, Sorey, Mariner, and Truesdell (1976) assumed that the same total discharge of $\mathrm{B}$ and $\mathrm{Cl}$ in the springs was supplied by a hot-water component with $375 \mathrm{mg} / \mathrm{L} \mathrm{Cl}$ and $18.8 \mathrm{mg} / \mathrm{L} \mathrm{B}$ and calculated a mass flux of $190 \mathrm{~kg} / \mathrm{s}$.

The average annual rate of $\mathrm{B}$ discharge from the caldera waters in Lake Crowley can also be used to estimate the flux of hot water through the hydrothermal system if it is assumed that most of the B in Lake Crowley was contributed by the hot-water reservoir. From 1960 to 1973, the average annual discharge of B from sources within the caldera was 136 metric tons per year (Sorey and Lewis, 1976, p. 789). This B flux could be supplied by a discharge of $300 \mathrm{~kg} / \mathrm{s}$ of water with a $B$ concentration of $14 \mathrm{mg} / \mathrm{L}$ (table 6, Casa Diablo well). Alternatively, the same annual discharge of boron could be supplied by $230 \mathrm{~kg} / \mathrm{s}$ of water having a boron concentration of $18.8 \mathrm{mg} / \mathrm{L}$, which applies to the $282^{\circ} \mathrm{C}$ water suggested by Fournier, Sorey, Mariner, and Truesdell (1976).

Comparisons of the estimates of mass flux based on boron discharge in individual hot springs with those based on boron discharge into Lake Crowley, indicate that as much as 20 percent of the upflowing hot water discharges in the subsurface and flows laterally into Lake Crowley. The magnitude of this hot-water flux is small compared with the total surface-water and ground-water discharge into Lake Crowley of 11,000 $\mathrm{L} / \mathrm{s}$, but it carries away a significant amount of heat. The rate of heat discharge from the caldera by convection and conduction is discussed in a later section.

\section{BORON DISCHARGE}

Smith (1976) compared the present-day rates of discharge of characteristic hot-spring elements such as B, $\mathrm{Li}, \mathrm{Cl}$, and As from the Long Valley hydrothermal system with amounts and ages of evaporite deposits in Searles Lake, downstream in the Owens River system. The salts in Searles Lake are less than 32,000 years old, on the basis of dating of interbedded mud layers, and approximately 70 percent of the $B$ in the salt layers can be accounted for by discharge from Long Valley at present rates for a 32,000-year period. A similar period of spring flow would account for observed quantities of $\mathrm{K}$ and $\mathrm{SO}_{4}$, whereas much of the $\mathrm{Li}$ and As from Long Valley was apparently lost in transport to Searles Lake. Smith also found that the amount of $\mathrm{Cl}$ now in Searles Lake is two to three times greater than the present Owens River could have supplied from Long Valley over 32,000 years, suggest- ing that Searles Lake received $\mathrm{Cl}$ from sources outside Long Valley.

In contrast, Bailey, Dalrymple, and Lanphere (1976) found evidence of a wide distribution of fossil gas vents, ancient sinter deposits, and areas of acid alteration, which indicates that surficial hydrothermal activity within the caldera was more extensive as well as more intensive in the past than at present. The extensive development of hydrothermal activity in lacustrine sediments that are about $0.3 \mathrm{~m}$.y. old, based on the 0.28 m.y. age of the interbedded Hot Creek rhyolite flow, suggests that the hydrothermal system may have reached maximum development at that time. Bailey, Dalrymple, Lanphere (1976) suggest a subsequent decline and areal restriction in surficial hydrothermal activity, owing to a general reduction in permeability of the intracaldera rocks caused by self-sealing processes of silicification, argillization, and zeolitization.

To reconcile the differences between these two estimates of the age of hot-spring activity, Smith (1976) suggests that large saline deposits remain undiscovered somewhere in the Owens River drainage or that only late states of spring activity contributed elements like $\mathrm{B}, \mathrm{Li}$, and $\mathrm{K}$ to the Owens River. Smith's analysis results from intensive search by the U.S. Geological Survey for borate deposits in the Owens River drainage, and it seems unlikely that large deposits of B, equivalent in amount to, say, 10 Searles Lake deposits, have been overlooked. A third alternative, suggested by $\mathrm{D}$. E. White (oral commun., 1976), is that hot-spring activity has been intermittent, and that the equivalent of one more Searles Lake deposit (presumably from the $0.3-$ m.y. activity) may be dispersed in earlier river drainages and sediment-filled basins.

The origin of the dissolved material in the hot-spring waters is of interest in this discussion. If magmatic fluids contribute the bulk of elements such as $\mathrm{B}, \mathrm{Li}, \mathrm{Cl}$, and $\mathrm{K}$, then it is possible that hydrothermal activity was continuous over the past $0.3 \mathrm{~m} . \mathrm{y}$. with changes in chemical composition of hot-spring waters occurring in relation to intermittent intrusive activity. Alternatively, if these elements are provided chiefly by hydrothermal leaching of the reservoir rocks, then the apparent variation in chemical discharge would most likely be related to variations in flow in the hydrothermal system.

As discussed by Ellis and Mahon (1964) and White (1968), evidence from deuterium and ${ }^{18} \mathrm{O}$ determinations in volcanic hydrothermal systems indicates that only minor (less than 5-10 percent) amounts of magmatic water are present in the circulating thermal fluids. Isotopic compositions of Long Valley waters, as discussed in the following section, are similar in this 
regard. However, the contribution of magmatic fluids cannot be completely eliminated, especially if variations in isotopic composition of hydrothermal fluids occurred over the 0.7-m.y. caldera history.

In relation to the leaching mechanism, Ellis and Mahon (1964) present data from short-term (20-day) leaching experiments involving volcanic rocks from New Zealand and temperatures from $150^{\circ} \mathrm{C}$ to $350^{\circ} \mathrm{C}$. They found that from 12 to 75 percent of the original chloride and from 3 to 30 percent of the original boron in the rocks could be removed within 20 days, and concluded that much of this "easily liberated" material was held on surfaces in the rocks rather than in solid solution in the rock silicates. Over long periods of time, additional releases of rock constituents associated with hydrothermal alteration of silicate structures would be expected. Further evidence from drill cores from New Zealand hydrothermal areas (Steiner, 1955) showed that more than 80-90 percent of the original chloride and boron in rhyolitic rocks from $200^{\circ} \mathrm{C}$ to $260^{\circ} \mathrm{C}$ is lost during natural alteration.

The reservoir volume required for leaching to supply the bulk of the chemical discharge from the Long Valley hydrothermal system can be calculated as a function of the percentage of original rock constituents which can be removed. The bases for these calculations are the estimates by Smith (1976) of the quantities of $\mathrm{B}, \mathrm{K}, \mathrm{Cl}$, and $\mathrm{Li}$ in Searles Lake which are supplied by the Long Valley system. These totals are listed in table 8 , along with measured element concentrations in the caldera rock.

These data show that $\mathrm{B}$ and $\mathrm{Cl}$ discharges place the greatest demand on leached rock volumes. Accordingly, in table 9 , the required rock volumes are listed as functions of the percentage of leachable $\mathrm{B}$ and $\mathrm{Cl}$. Corresponding reservoir thicknesses are calculated by assuming a reservoir area of $220 \mathrm{~km}^{2}$, which covers the western three-fifths of the caldera.

TABLE 8.-Measured concentrations of chemical elements in Long Valley rocks and total amounts discharged from Long Valley into Searles Lake

\begin{tabular}{|c|c|c|}
\hline Element & $\begin{array}{l}\text { Concentration in } \\
\text { rock samples } \\
\text { (ppm) }\end{array}$ & $\begin{array}{c}\text { Total amount } \\
\text { discharged } \\
\left(\mathrm{kg} \times 10^{9}\right.\end{array}$ \\
\hline 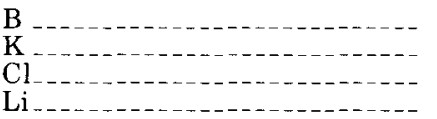 & $\begin{array}{c}330-53 \\
416,000-20,000 \\
5300-400 \\
320-49\end{array}$ & $\begin{array}{r}7 \\
4.4 \\
6140 \\
1\end{array}$ \\
\hline \multicolumn{3}{|c|}{$\begin{array}{l}{ }^{1} \text { Spectrographic analysis by C. S. Annell, USGS, Reston, Va. } \\
{ }^{2} \text { From Smith (1976). } \\
{ }^{3} \text { Range for } 9 \text { samples of Bishop Tuff from Owens River gorge. . } \\
{ }^{4} \text { Sheridan (1965). } \\
\text { } \text { Range for } 6 \text { samples of intracaldera early rhyolite and Bishóp Tuff from Owens River } \\
\text { orge. } \\
{ }^{6} \text { Calculated from total B, assuming Cl/B }=20 \text {. }\end{array}$} \\
\hline
\end{tabular}

These results indicate that under certain conditions the reservoir volume and thickness required for leaching to supply the salts discharged from Long Valley are realistic. One condition is that significant percentages of the original $\mathrm{B}$ and $\mathrm{Cl}$ in the reservoir rocks be removed. Considering a reservoir thickness of $2 \mathrm{~km}$ as reasonable, and accounting for an additional period of comparable hydrothermal activity around $0.3 \mathrm{~m} . \mathrm{y}$. ago, at least 30 percent of the $\mathrm{B}$ and 60 percent of the $\mathrm{Cl}$ must have been leached. The New Zealand data discussed above suggest that this is certainly possible. A second condition is that the areal extent of the reservoir be close to the assumed $220 \mathrm{~km}^{2}$. If it were considerably more areally restricted, the required reservoir thickness would become unreasonably large, unless the 80-90 percent $\mathrm{B}$ and $\mathrm{Cl}$ leaching found in New Zealand has also occurred in Long Valley. If these levels of element removal have not been approached in Long Valley and if the hydrothermal circulation system is not as areally extensive as assumed here, then magmatic sources must have contributed significantly to the chemical and probably the thermal discharge from the Long Valley caldera. Additional lithologic data from deep test holes in the western caldera are required to resolve these questions.

The contrast between the age of the saline deposits of Searles Lake and that of the earliest hydrothermal activity within the caldera, and the inference of extreme climatic and hydrologic variations during the intervening period, lead to the conclusion that the hot springs and associated hydrothermal activity have been intermittent. This matter is considered further in a later section in terms of the influence of the age of hydrothermal activity on heat-flow requirements from an underlying magma chamber.

TABLE 9.-Size of leached reservoir required to supply total discharges of $\mathrm{B}$ and $\mathrm{Cl}$ for various changes in $\mathrm{B}$ and $\mathrm{Cl}$ concentrations in the reservoir rock

\begin{tabular}{lccc}
\hline Element & $\begin{array}{c}\text { Change in element } \\
\text { content of rock } \\
\text { (percent) }\end{array}$ & $\begin{array}{c}\text { Leached-rock } \\
\text { volume }^{2} \\
\left(\mathrm{~km}^{3}\right)\end{array}$ & $\begin{array}{c}\text { Leached-rock } \\
\text { thickness }^{3} \\
\left(\mathrm{~km}^{3}\right)\end{array}$ \\
\hline $\mathrm{B}$ & 75 & 100 & 0.45 \\
& 50 & 150 & .68 \\
& 25 & 300 & 1.4 \\
$\mathrm{Cl}$ & 10 & 750 & 3.4 \\
& 75 & 214 & 0.97 \\
& 50 & 320 & 1.5 \\
& 25 & 640 & 2.9 \\
& 10 & 1600 & 7.3
\end{tabular}

'Assuming original rock $\mathrm{B}=40 \mathrm{ppm}, \mathrm{Cl}=350 \mathrm{ppm}$.

${ }^{2}$ Volume $=$ Amount of element discharged/(change in element content of rock $\times$ bulk density of rock).

${ }^{3}$ Assuming reservoir area $=220 \mathrm{~km}^{2}$. 
STABLE ISOTOPES

Comparisons of ${ }^{18} \mathrm{O}$ and deuterium contents of hot and cold Long Valley waters are useful in understanding the caldera's hydrologic system. In comparison with most other isotopically studied hydrothermal convection systems, the Long Valley system appears unusual in terms of the large areal variability in isotopic contents of its meteoric waters and clear evidence of the involvement of at least two different meteoric waters in the hot-spring fluids.

Figure 11 is a plot of stable isotope date in standard $\delta$ values, parts per mill $(\%)$ relative to SMOW, for various waters which were sampled at the locations shown in figure 12. Mariner and Willey (1976) used data from samples collected in 1972, represented by the dark circles, to suggest that water similar to i (Big Springs) was typical of the recharge to the hydrothermal system. The bulk of the flow in Big Springs probably originates in the Deadman Creek drainage basin and moves eastward at shallow depth through the exposed basalt flows. As meteoric water percolates deeper underground and is heated, the oxygen isotopes react with oxygen in the rocks while hydrogen isotopes remain almost unchanged. Thus, the isotopic composition of the circulating water would shift from $i$ to $b$. Water b from a well at Casa Diablo Hot Springs was interpreted by Mariner and Willey (1976) to be a sample of the hottest water in the system, having a

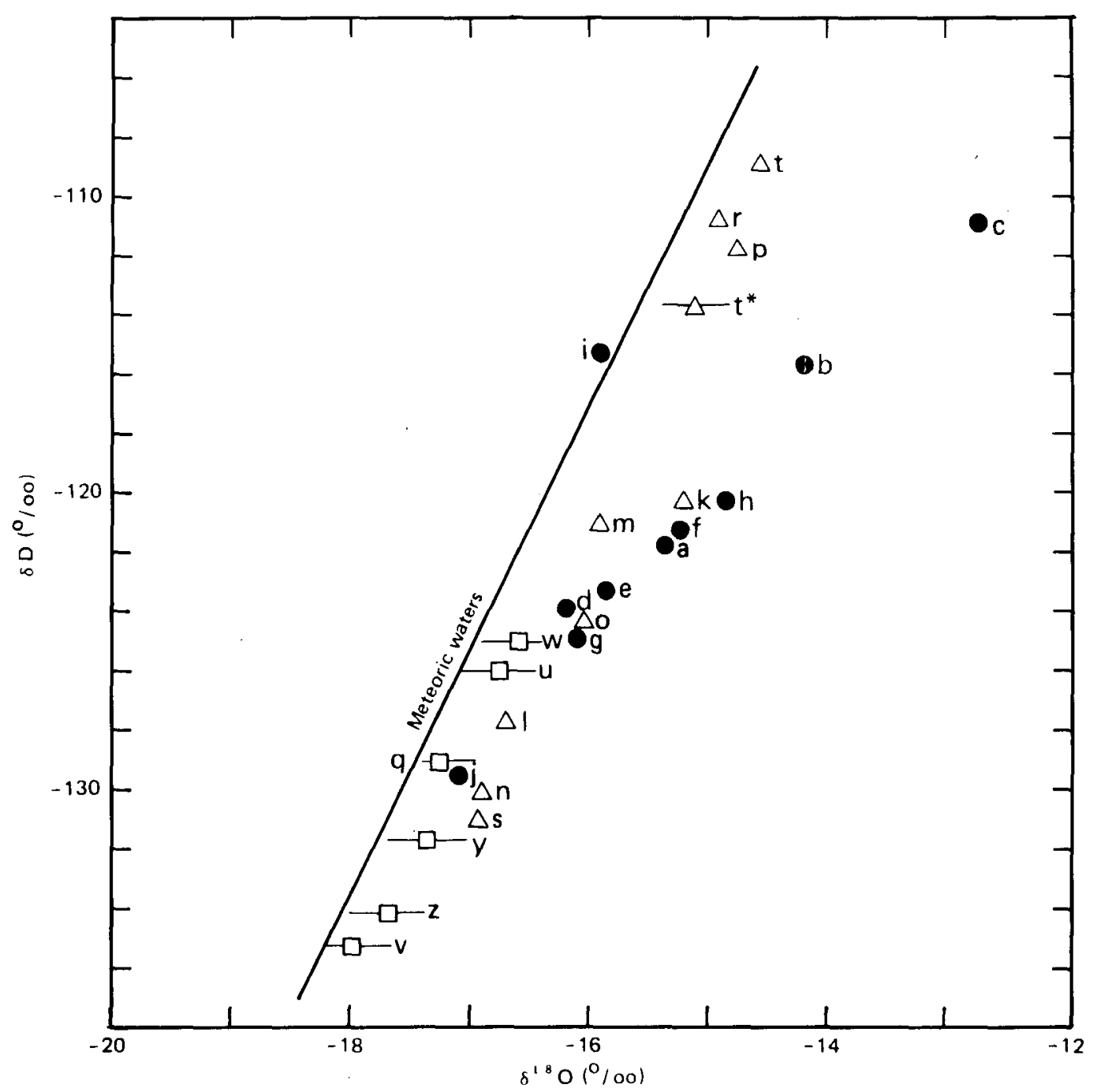

Figure 11.-Relations between concentrations of deuterium and ${ }^{18} \mathrm{O}$ in Long Valley waters. Closed circles represent samples collected in 1972, open triangles represent 1975 samples, open squares represent 1976 samples for which ${ }^{18} \mathrm{O}$ concentrations have not been determined. Sample locations given in figure 12 and table 7. 
geochemically estimated temperature at depth of $219^{\circ} \mathrm{C}$. During upflow, if this water mixed in different proportions with cold water similar to $\mathrm{j}$ (from an artesian well near the northeast rim), the isotopic contents of the various hot and warm springs could be obtained. The lineation of points representing these springs between end points $b$ and $j$ tends to support this mixing model.

Additional data from cold springs sample in 1975 and 1976 and annual variations in $\mathrm{D} / \mathrm{H}$ ratios of snow samples collected at Mammoth Mountain midstation (Friedman and Smith, 1970, 1972; Smith, unpub. data, 1976) allow somewhat more detail in the analysis of recharge and mixing relationships. The more recent data are represented by the open symbols in figure 11 . Point $t *$ for the Mammoth Mountain spring was calculated using an average $\delta \mathrm{D}$ of $-114 *$ from snow samples for the years 1970-76 over which a range of -110 to -118 occurred. This point, along with points $r, p$, and $t$, which also represent cold waters from the west rim but are based only twice 1975 data, suggests that recharge water for the hydrothermal system may be slightly heavier than $i$. If this were so, water b could be a mixed water rather than an end member, consistent with the geothermometer analysis by Fournier, Sorey, Mariner, and Truesdell (1976). Water c from the Hot Bubbling Pool has been strongly fractionated probably by evaporation, similar to many other hot springs of high surface temperatures but without surface discharge.

The more recent $\delta \mathrm{D}$ date in figure 11 also indicate differences between cold waters around the north, east, and sourth rims. Water just beyond the east rim (v) is lightest at $-135 \%$. Ground waters from the north and northeast rims $(j, n, q$, and $y)$ range in $\delta D$ from -129 to $-132 \%$. The south rim waters (l and $w)$ are heaviest at -125 to $-128 \%$, and similar to the Hartley Springs water $(u)$ from beyond the northwest rim of the caldera. The $\delta \mathrm{D}$ content of water $\mathrm{z}$ from a windmill on the northeast flank of the resurgent dome is quite light at $-134 \%$. If this water originates as precipitation on the resurgent dome, as suggested by the water table map in figure 10 , the dome waters must be relatively light. A contribution of recharge from the

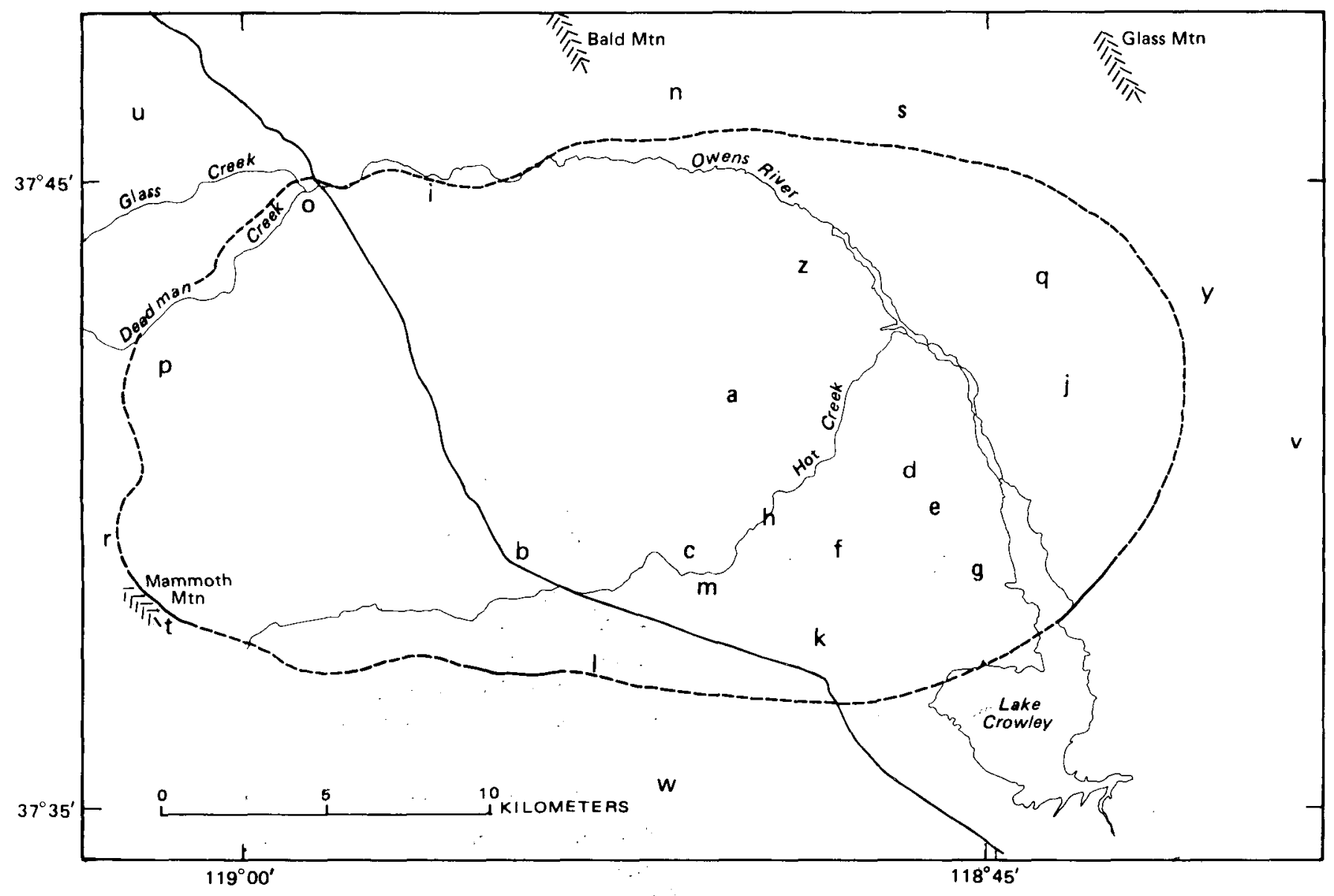

Figure 12.-Map of Long Valley caldera showing location of sampling points for deuterium and ${ }^{18} \mathrm{O}$ analyses. 
Lookout Mountain area on the dome to Big Springs might account for point $i$ being lighter than the other west rim waters.

In view of temporal variations in $\mathrm{D} / \mathrm{H}$ ratios of snowfall, a complete set of sample from springs at one or more times would be desirable. However, the data in figure 11, along with our knowledge of ground-water movements in the shallow system, suggest several sources of cold, diluting water in the thermal springs, rather than the single source (i) indicated by Mariner and Willey (1976). For the Casa Diablo Hot Springs area and the warm springs west of the Hot Creek gorge, the south rim and resurgent dome are the most likely sources. For springs in the gorge and Little Hot Creek, the north rim and resurgent dome and possibly the south rim are indicated. Because shallow recharge from the northeast and east rim flows into the Owens River and Lake Crowley, it would not be available for mixing with hot-springs waters further to the west as was previously suggested.

The isotope data do suggest, however, that some recharge from the higher altitudes on the flanks of Glass Mountain may percolate down the rim fractures and flow laterally toward the southwest through permeable zones in the Bishop Tuff. A drill-stem sample of questionable quality from a depth of $1.46 \mathrm{~km}$ in Republic Geothermal's $2.11 \mathrm{~km}$-deep test hole near spring $\mathrm{f}$ (fig. 12) yielded a $\delta \mathrm{D}$ of $-126 \%,(\mathrm{Cl}=100 \mathrm{mg} / \mathrm{L})$. If this sample was contaminated by drilling fluid, which had a measured $\delta \mathrm{D}$ of $-114 \%$, the relatively cold waters in the Bishop Tuff at this location may have $\mathrm{D} / \mathrm{H}$ ratios closer to the -129 to $-132 \%$ range for the northeastrim waters.

\section{THERMAL GHARACTERISTICS OF THE HYDROTHERMAL SYSTEM}

Measurements of thermal anomalies would seem the most obvious indication of potentially valuable geothermal areas. These anomalies may take the form of hot-spring and fumarolic discharge, above-normal ground temperature detectible by infrared imagery or snow calorimetry, and above-normal near-surface heat flow, geothermal gradient, and temperature. As noted by Lachenbruch, Sass, Munroe, and Moses (1976), measurements of heat flow, unlike other geophysical measurements, may contain direct information on past geologic events because of the long time required for a thermal disturbance to equilibrate by conduction in earth materials.

Unfortunately, the time variable and the interaction of convective (or advective) and conductive heattransfer mechanisms can produce large variations from one area to the next and make interpretation of thermal and hydrologic conditions at depth uncertain. With due consideration for these limitations, investigations of regional heat flow and the near-surface thermal regime in the Long Valley area were undertaken. These studies are described by Lachenbruch, Sass, Munroe, and Moses (1976) and Lachenbruch, Sorey, Lewis, and Sass (1976); the results which are pertinent to our analysis of the hydrothermal system are discussed below.

\section{REGIONAL HEAT FLOW}

Temperature-gradient and heat-flow measurements were made at 11 stations in the vicinity of (but outside of) Long Valley caldera (Lachenbruch, Sass, Munroe, and Moses, 1976). Evaluation of the thermal anomaly associated with magma beneath the caldera shows no conspicuous effect of the transition between the Sierra Nevada and Basin and Range provinces, possibly a small local heat-flow anomaly beyond the east rim of the caldera ( $2.2 \mathrm{HFU})$, and a very substantial anomaly beyond the west rim (3.8 HFU).

Lachenbruch, Sass, Munroe, and Moses (1976) conclude that heat-conduction models for the near-normal heat flow at the east rim suggest that magma beneath the east part of the caldera might have been exhausted during eruption of the Bishop Tuff $0.7 \mathrm{~m}$.y. ago and that the resurgent dome, which subsequently formed in the west-central caldera, overlies a residual magma chamber more circular in plan than the original magma chamber that supplied the Bishop Tuff. High heat flow indicated by the measurement near the west rim is attributed either to a simple shallow magma chamber beneath the western caldera or to recent local magmatism along the Sierra frontal fault system.

The analysis of heat-conduction models of cooling magma further suggests that the Long Valley caldera is the surface expression of a deep magmatic system, because an upper-crustal magma chamber could not have furnished molten material throughout the 2-m.y. eruptive history since the early eruptions of the Glass Mountain Rhyolite unless it were resupplied with heat from deep crustal sources. Calculations of heat supply by crustal intrusion of mantle basalt yield minimum intrusion rates of the order of $1 \mathrm{~m}$ per century, which implies accelerated crustal spreading.

\section{THERMAL REGIME WITHIN THE CALDERA}

Thermal measurements were made in 29 holes drilled to depths of $30 \mathrm{~m}$ or less and in 10 deeper holes (from 52 to $325 \mathrm{~m}$ ) within the caldera. Well locations are shown in plate $1 ; \mathrm{LV}$ designates the shallow $(30 \mathrm{~m})$ 
holes; $\mathrm{CH}$ designates the deepper holes in which cores were obtained. A few thermal conductivity measurements were made to permit rough estimates of conductive heat flows. Selection of drilling sites and depths involved a compromise between areal coverage and vertical definition. As noted by Lachenbruch, Sorey, Lewis, and Sass (1976), the farther beneath the surface we extend our observations the more we can expect to learn about the hydrothermal system associated with the potential resource, but the more costly and time consuming each observation becomes. In addition, adequate information on lateral variability may prove essential to subsequent selection of sites for deep drilling.

Temperature profiles from all the test holes are plotted in figure 13; identification of individual profiles in the 30-m holes is given by Lachenbrich, Sorey, Lewis, and Sass (1976). Temperatures at $15 \mathrm{~m}$ are shown in figure 14 and near-surface conductive heat flows in figure 15. The former differs somewhat from the corresponding map in Lachenbruch, Sorey, Lewis, and Sass (1976), because it is based on additional data. Methods of drilling and completion to minimize effects of fluid circulation in boreholes are described by Lachenbruch, Sorey, Lewis, and Sass (1976). Thermal conductivity measurements and lithologic characteristics of the rocks at each core-hole site are listed in table 10 .

In contrast to the regional temperature and heatflow data, thermal data obtained within the caldera are strongly influenced by the hydrologic system. Analysis of the thermal regime has provided useful information on near-surface $(0-300 \mathrm{~m})$ hydrology, as discussed below. The shallow thermal observations also help to define the nature and extent of the recharge and discharge areas for the deeper hydrothermal system and suggest areas where the shallow ground-water subsystem is relatively impermeable and shallow temperature gradients might be used to estimate temperatures in the underlying deep subsystem. However, additional information from deep test drilling is needed to evaluate satisfactorily the role of shallow thermal observations in geothermal exploration in Long Valley.

Temperature profiles in figure 13 show gradients associated with conductive heat flows of 0 to 50 HFU for thermal conductivities (table 11) of about $2 \mathrm{mcal} /$ $\left(\mathrm{s}^{\circ} \mathrm{C} \mathrm{cm}\right.$ ). Temperatures at $15 \mathrm{~m}$ (and as shallow as $6 \mathrm{~m}$ ) correlate well with the character of the thermal gradients to $30 \mathrm{~m}$, as discussed by Lachenbruch, Sorey, Lewis, and Sass (1976). The grouping of temperature profiles in figure 13 is suggested by the following. Group I regimes, representing heat flows less than 1 HFU, are characteristic of the outer margin of the caldera, suggesting that this is an area of hydrologic

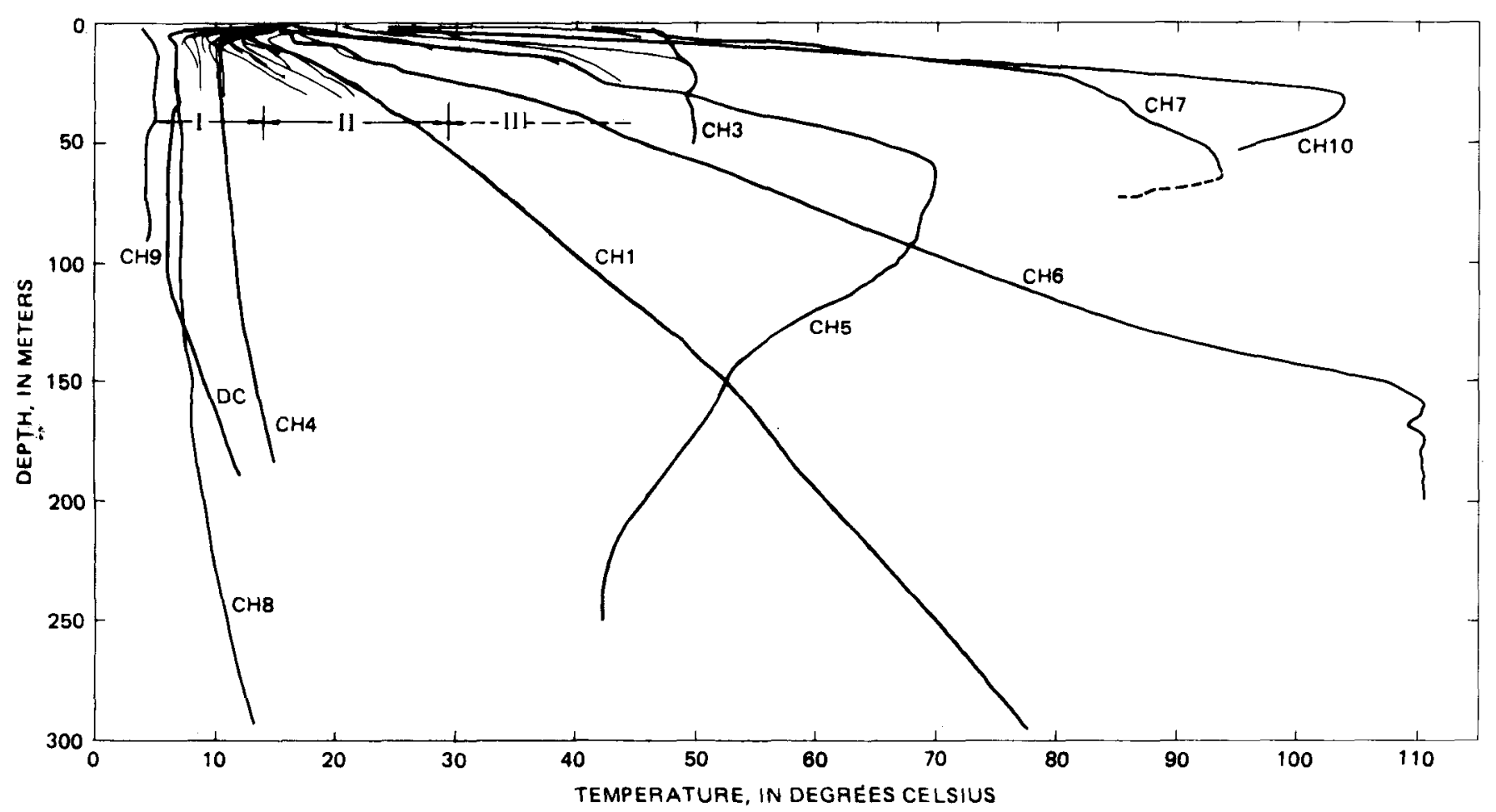

FIGURE 13.-Temperature profiles from core holes and shallow holes in Long Valley caldera. Data from Lachenbruch, Sorey, Lewis, and Sass (1976), except for $\mathrm{CH} 8,9,10$. 
recharge. Group II regimes, representing conductive heat flows of about 4 to $8 \mathrm{HFU}$, show little influence of convection down to $300 \mathrm{~m}$ in at least one location (CH-1). Group III regimes, representing larger heat flows ranging to more than $50 \mathrm{HFU}$, show considerable variability with depth and more variability with time than gradients in the other groups (Lachenbruch, Sorey, Lewis, and Sass, 1976). Temperature profiles in group III indicate that they are characteristic of areas of subsurface discharge of hot or warm ground water; the hot springs discharge in a fault zone characterized by near-surface regimes in groups II and III. Temperature reversals in wells $\mathrm{CH}-3, \mathrm{CH}-5, \mathrm{CH}-7$, and $\mathrm{CH}-10$ and temperature and heat-flow patterns (figs. 14 and 15 ), indicate that warm ground water moves laterally from Hot Creek gorge toward Lake Crowley. An estimate of the heat discharged by this subsurface flow is discussed in the next section.

Heat flows at the group II sites are comparable to the hydrologically undisturbed value of about 4 HFU measured in granite at Devils Postpile just beyond the west rim of the caldera (Lachenbruch, Sass, Munroe, and Moses, 1976), although the agreement is probably fortuitous. One explanation for the group II profiles is that they occur in areas where the $200^{\circ} \mathrm{C}$ reservoir temperatures (from chemical geothermometers) exist at depths of about $1 \mathrm{~km}$ or less and heat transfer in overlying rock of low permeability is basically conductive.

One core hole in group III, CH-6, was drilled on the resurgent dome in Little Antelope Valley, and encountered the highest temperature $\left(110^{\circ} \mathrm{C}\right)$ in any of the test holes. The nearly isothermal part of the temperature profile below $165 \mathrm{~m}$ indicates that circulation of heated

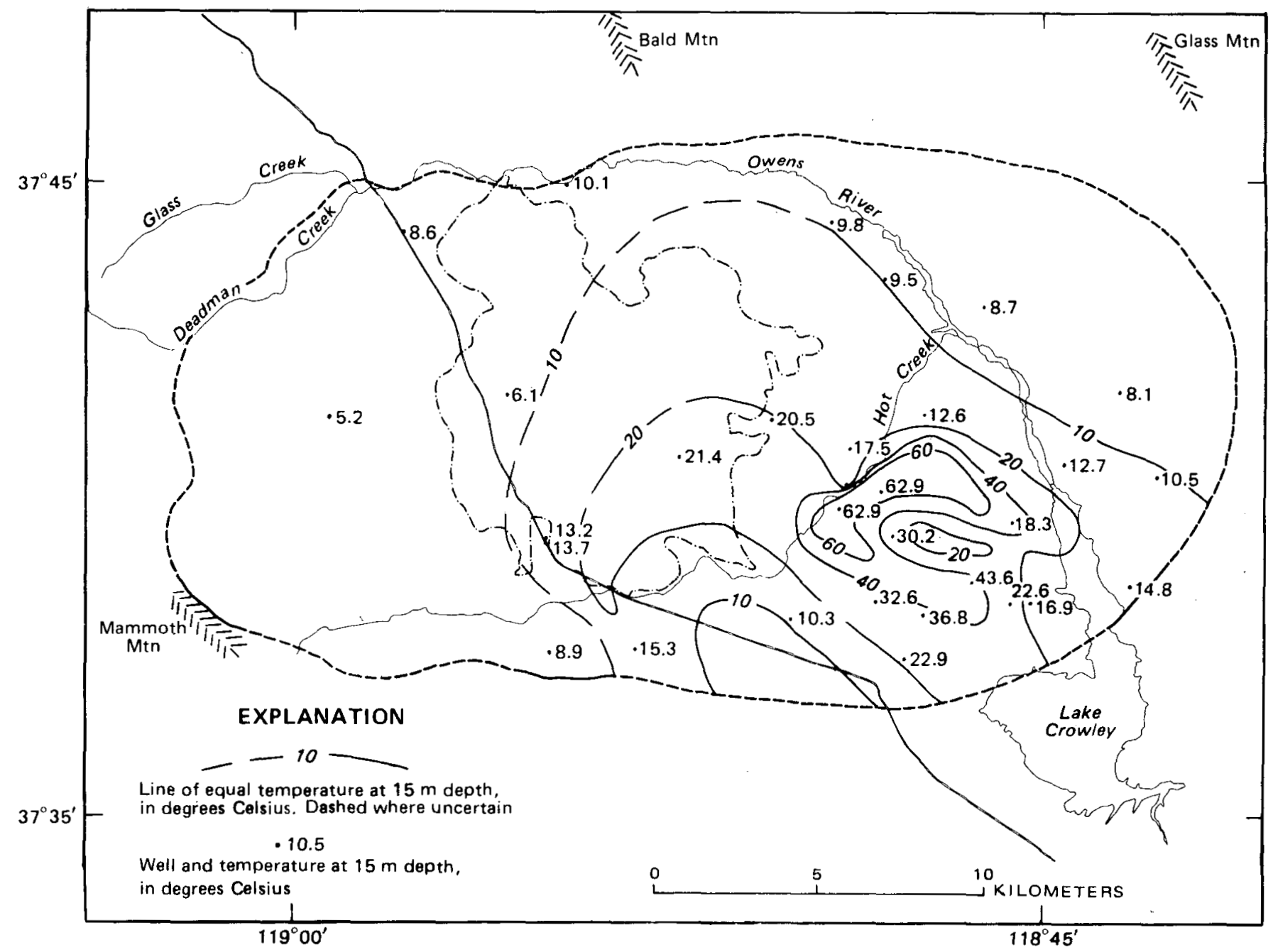

Figure 14.--Map of Long Valley caldera showing temperature at a depth of $15 \mathrm{~m}, 1973-74$. Data from Lachenbruch, Sorey, Lewis, and Sass (1976) and Lewis (1974). (Dashed-dot outlines early rhyolite outcrops on resurgent dome.) 
TABLE 10.-Generalized lithologic descriptions and thermal conductivity data from cores and cuttings at test-hole sites in Long Valley caldera

\begin{tabular}{|c|c|c|c|c|}
\hline $\begin{array}{l}\text { Hole } \\
\text { No. }\end{array}$ & Location & $\underset{(\mathrm{m})}{\text { Depth }}$ & Lithology & $\begin{array}{l}\text { Thermal } \\
\text { conductivity } \\
\left.\text { (mcal/(cms. }{ }^{\circ} \mathrm{C}\right) \text { ) }\end{array}$ \\
\hline \multirow[t]{2}{*}{$\mathrm{CH}-1$} & \multirow{2}{*}{$\begin{array}{l}3 \mathrm{~S} / 29 \mathrm{E}-19 \mathrm{C} \\
\text { Cashbaugh } \\
\text { Ranch }\end{array}$} & $0-160$ & $\begin{array}{l}\text { Tuffaceous sediments, alternately coarse } \\
\text { and fine, some clay-alteration }\end{array}$ & $1.8-2.1$ \\
\hline & & $160-305$ & $\begin{array}{l}\text { Tuffaceous sediments, hydrothermally } \\
\text { altered with permeability reduction }\end{array}$ & $1.7-2.5$ \\
\hline $\mathrm{CH}-3$ & $\begin{array}{l}3 \mathrm{~S} / 29 \mathrm{E}-27 \mathrm{~L} \\
\text { West of Lake } \\
\quad \text { Crowley }\end{array}$ & $0-52$ & Porphyritic biotite rhyolite flow & $2.1-2.4$ \\
\hline $\mathrm{CH}-4$ & $\begin{array}{l}3 \mathrm{~S} / 30 \mathrm{E}-19 \mathrm{M} \\
\text { East rim }\end{array}$ & $\begin{array}{c}0-90 \\
90-187\end{array}$ & $\begin{array}{l}\text { Ash and sediments } \\
\text { Medium to coarse sand }\end{array}$ & $\begin{array}{r}2.1-2.4 \\
2.6\end{array}$ \\
\hline $\mathrm{CH}-5$ & $\begin{array}{l}4 \mathrm{~S} / 29 \mathrm{E}-5 \mathrm{~B} \\
\mathrm{E} \text {. of Whit- } \\
\text { more Hot Spring }\end{array}$ & $\begin{array}{c}0-60 \\
60-120 \\
120-200 \\
210-265\end{array}$ & $\begin{array}{l}\text { Tuffaceous sediments } \\
\text { Pebbly sand with obsidian and metamorphic clasts } \\
\text { Biotite rhyolite pumiceous tuff } \\
\text { Hornblende-biotite rhyolite tuff }(0.3 \text { my old })\end{array}$ & $\begin{array}{l}2.0-2.3 \\
2.1-2.8\end{array}$ \\
\hline $\mathrm{CH}-6$ & $\begin{array}{l}3 \mathrm{~S} / 28 \mathrm{E}-22 \mathrm{~F} \\
\text { Little Ante- } \\
\text { lope Valley }\end{array}$ & $\begin{array}{r}0-150 \\
150-208\end{array}$ & $\begin{array}{l}\text { Clay-altered tuff } \\
\text { Altered tuff with sulfide-bearing silica } \\
\text { veins }\end{array}$ & $\begin{array}{l}2.9-3.5 \\
3.4-5.2\end{array}$ \\
\hline $\mathrm{CH}-7$ & $\begin{array}{l}3 \mathrm{~S} / 29 \mathrm{E}-19 \mathrm{R} \\
\text { Near Little } \\
\text { Alkali Lake }\end{array}$ & $\begin{array}{c}0-70 \\
75-165\end{array}$ & $\begin{array}{l}\text { Sand } \\
\text { Altered sediments (silicified, argillized) }\end{array}$ & $\overline{3.5-3 . \overline{8}}$ \\
\hline $\mathrm{CH}-8$ & $\begin{array}{l}3 \mathrm{~S} / 28 \mathrm{E}-18 \mathrm{D} \\
\text { Smokey Bear } \\
\quad \text { Flat }\end{array}$ & $\begin{array}{c}0-30 \\
30-100 \\
100-325\end{array}$ & $\begin{array}{l}\text { Pumice } \\
\text { Rhyolite flow } \\
\text { Aphyrite rhyolite tuff }\end{array}$ & $1.8-2.3$ \\
\hline $\mathrm{CH}-9$ & $\begin{array}{l}3 \mathrm{~S} / 27 \mathrm{E}-20 \mathrm{H} \\
\text { Upper Dry } \\
\text { Creek }\end{array}$ & $\begin{array}{r}0-10 \\
10-50 \\
50-85 \\
88-92\end{array}$ & $\begin{array}{l}\text { Pumice } \\
\text { Porphyritic vesicular basalt } \\
\text { Hornblende-plagioclase andesite (dense } \\
\text { to vesicular) } \\
\text { Olivine-plagioclase basalt }\end{array}$ & $\begin{array}{r}3.0-3.6 \\
3.8-4.0 \\
3.3\end{array}$ \\
\hline $\mathrm{CH}-10$ & $\begin{array}{l}3 \mathrm{~S} / 29 \mathrm{E}-30 \mathrm{E} \\
\text { Hot Creek } \\
\text { Gorge }\end{array}$ & $0-53$ & Altered Hot Creek rhyolite & ----- \\
\hline $\mathrm{DC}$ & $\begin{array}{l}2 \mathrm{~S} / 27 \mathrm{E}-34 \mathrm{~A} \\
\text { Deadman } \\
\text { Creek }\end{array}$ & $\begin{array}{c}0-50 \\
50-100 \\
100-190 \\
190-193\end{array}$ & $\begin{array}{l}\text { Pumiceous sediments } \\
\text { Trachyandesite } \\
\text { Sand } \\
\text { Pumiceous tuff }\end{array}$ & $\begin{array}{r}3.6-4 . \overline{4} \\
1.7-2.4 \\
1.7\end{array}$ \\
\hline
\end{tabular}

TABLE 11.-Previous estimates of convective heat discharge from Long Valley caldera

\begin{tabular}{|c|c|c|c|}
\hline Reference & Method & $\begin{array}{l}\text { Reservoir } \\
\text { tempera- } \\
\text { ture }\left({ }^{\circ} \mathrm{C}\right)\end{array}$ & $\begin{array}{c}\text { Convective } \\
\text { heat flow } \\
\left(\times 10^{7} \mathrm{cal} / \mathrm{s}\right)\end{array}$ \\
\hline $\begin{array}{l}\text { Sorey and Lewis } \\
\quad(1976)\end{array}$ & $\begin{array}{l}\text { Measured springflow } \\
\text { Boron discharge }\end{array}$ & $\begin{array}{l}210 \\
210\end{array}$ & $\begin{array}{l}4.3 \\
5.4\end{array}$ \\
\hline White (1965) & Boron discharge & 180 & 7.0 \\
\hline $\begin{array}{l}\text { Fournier, Sorey, } \\
\text { Mariner, and } \\
\text { Truesdell (1976) }\end{array}$ & $\begin{array}{l}\text { Measured springflow } \\
\text { Boron discharge }\end{array}$ & $\begin{array}{l}282 \\
282\end{array}$ & $\begin{array}{l}5.3 \\
6.6\end{array}$ \\
\hline
\end{tabular}

ground water is influencing the thermal regime in the upper $200 \mathrm{~m}$. In contrast, the temperature profile in $\mathrm{CH}-8$, drilled in Smokey. Bear Flat $5.6 \mathrm{~km}$ northwest of CH-6 and within the keystone graben on the resurgent dome, is characteristic of the low-heat-flow regimes of group I. Similar low temperatures and isothermal temperature profiles were found at other core holes drilled farther west of $\mathrm{CH}-8$, suggesting that the circulation of relatively cold ground water may be masking evidence of deeper thermal activity in the western third of the caldera. It is clear from the thermal data in figure 13, that deepening any of the holes by 50 to 100 
m could lead to surprises, and that downward extrapolation of near-surface temperature gradients is hazardous.

In general, our conceptual model of the Long Valley hydrothermal system ignores the details of the shallow thermal and hydrologic regimes. However, the data discussed above were used in calculating the total heat discharge from the caldera, which provides a check on the estimates from chemical mixing models of reservoir temperatures and hot-water discharge and also provides a necessary constraint on heat-flow simulation with the numerical model.

\section{NATURAL HEAT DISCHARGE}

The natural rates of heat and fluid discharge from the Long Valley caldera provide useful constraints on the simulation of the hydrothermal system. Published estimates of the convective heat discharge are given in table 11. The estimates by Sorey and Lewis (1976) should have been corrected for variable fluid density to yield from 5.1 to $6.4 \times 10^{7} \mathrm{cal} / \mathrm{s}$. Calculations based on measured springflow use geochemical mixing models to estimate reservoir temperature and mixing ratios between hot-water and cold-water components. The rate at which heat leaves the hydrothermal reservoir by convection (Q) is computed from

$$
Q=M\left(h_{r}-h_{o}\right)
$$

where $\mathbf{M}=$ mass discharge of hot water from the reservoir, $h_{r}=$ enthalpy of hot water, and $h_{o}=$ enthalpy of

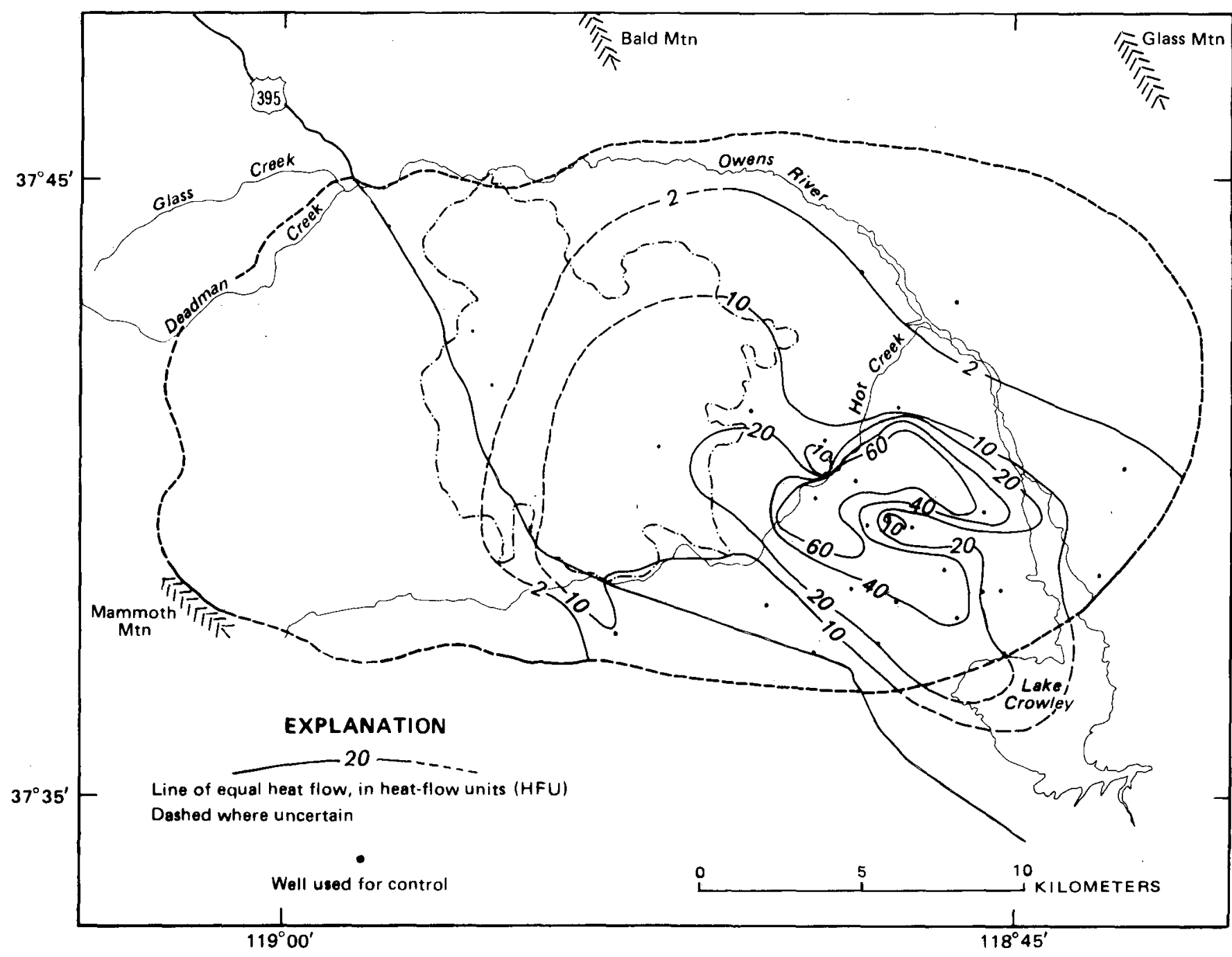

Figure 15.-Map of Long Valley caldera showing near-surface conductive heat flow, 1973-74. Based on temperature data from Lachenbruch, Sorey, Lewis, and Sass (1976) and Lewis (1974) and an assumed thermal conductivity of $2.0 \mathrm{mcal} /\left(\mathrm{cm} \mathrm{s}{ }^{\circ} \mathrm{C}\right.$ ). (Dashed-dot line outlines early rhyolite outcoprs on resurgent dome.) 
recharging meteoric water $(\simeq 10 \mathrm{cal} / \mathrm{gm})$. The corrected estimate of $5.1 \times 10^{7} \mathrm{cal} / \mathrm{s}$ noted above is based on a mass discharge of $250 \mathrm{~kg} / \mathrm{s}$ at $210^{\circ} \mathrm{C}$ and $214 \mathrm{cal} / \mathrm{gm}$. The corresponding estimate by Fournier, Sorey, Mariner, and Truesdell (1976) of $5.3 \times 10^{7} \mathrm{cal} / \mathrm{s}$ is essentially the same, even though it is based on a reservoir temperature of $282^{\circ} \mathrm{C}$. This is because the same total flux of boron and chloride from the hot-water reservoir was assumed, but higher calculated concentrations of these elements in the hot water are involved. The result is a lower mass discharge of $190 \mathrm{~kg} / \mathrm{s}$ used in equation (1).

Convective heat-flow estimates based on boron discharge from Lake Crowley involve calculating the mass discharge of hot water from the reservoir needed to supply the average annual tonnage of boron leaving the caldera. Using similar assumptions as to boron and heat contents in the hydrothermal reservoir, the convective heat-flow estimates in table 11 exceed the corresponding estimates based on measured springflow by 25 percent. As discussed previously, these differences are due in part to unmeasured subsurface discharge of hot water from the hot-spring conduits.

To determine the total heat discharge by conductive and convective processes and to test the adequacy of the mixing-model results, we have calculated the total heat discharge at the land surface. For the purpose of the following analysis, the heat discharge from the caldera is subdivided into three elements : (1) convective heat discharge by springflow; (2) near-surface conductive heat discharge; and (3) advective heat discharge by ground-water flow beyond the caldera margin into Lake Crowley.

\section{CONVECTIVE HEAT DISCHARGE BY SPRINGFLOW}

The estimate of convective heat discharge by springflow (table 12) is based on data of Sorey and Lewis (1976, tables 1 and 2) and Lewis (1974). Discharge temperatures are measured values except for the springs discharging into Hot Creek in Hot Creek gorge, where the discharge is assumed to be $93^{\circ} \mathrm{C}$ (boiling temperatures at an altitude of $2,120 \mathrm{~m}$ ) and the Fish Hatchery Springs, where the weighted-average discharge temperature is $14.4^{\circ} \mathrm{C}$ (Sorey, 1975b, p. 4). Net enthalpy per gram of discharge from each spring or spring area is calculated as the difference between the discharge temperature and an assumed average annual temperature of $8^{\circ} \mathrm{C}$ at the land surface.

The estimate of total convective heat discharge by springflow, about $2.9 \times 10^{7} \mathrm{cal} / \mathrm{s}$, is believed to be conservatively low, because several nonthermal springs in Long Valley that have sizable discharges at more than $8^{\circ} \mathrm{C}$ were not included.

\section{NEAR-SURFACE CONDUCTIVE HEAT DISCHARGF}

The second element of heat discharge-near-surface conductive heat discharge-was estimated in the following manner. As the first step in the calculation, the average annual near-surface geothermal gradient at each test-well site was computed as the difference between the observed temperature at a depth of $15 \mathrm{~m}$ and an assumed average annual temperature of $8.0^{\circ} \mathrm{C}$ at the land surface, divided by the $15-\mathrm{m}$ depth interval. A depth of $15 \mathrm{~m}$ was selected because repeated measurements in most of the test wells indicated very small seasonal fluctuations in temperature at that

TABLE 12.-Convective heat discharge by springflow from Long Valley caldera [Temperature and discharge data from Sorey and Lewis (1976, tables 1-2)]

\begin{tabular}{|c|c|c|c|c|c|}
\hline Spring or spring area & $\begin{array}{c}\text { Discharge } \\
(\mathrm{L} / \mathrm{s})\end{array}$ & $\underset{\left({ }^{\circ} \mathrm{C}\right)}{\text { Temperature }}$ & $\begin{array}{c}\text { Net enthalpy } \\
\text { (cal/g) }\end{array}$ & $\begin{array}{c}\text { Density of water } \\
\left(\mathrm{g}^{\prime} / \mathrm{cm}^{3}\right)\end{array}$ & $\begin{array}{l}\text { Heat discharge } \\
\left(\times 10^{5} \mathrm{cal} / \mathrm{s}\right)\end{array}$ \\
\hline $\begin{array}{l}\text { 1. Springs in Hot Creek gorge } \\
\text { 2. Fish Hatchery Springs } \\
\text { 3. Little Hot Creek }{ }^{1} \\
\text { 4. Casa Diablo Hot Pool } \\
\text { 5. Whitmore Hot Springs } \\
\text { 6. Big Alkali Lake }{ }^{2} \\
\text { 7. Little Alkali Lake }{ }^{2} \\
\text { 8. Chance Spring } \\
\text { 9. T3S/R29E-27, 28 } \\
\text { 10. T3S/R29E-34K } \\
\text { 11. T3S/R29E-3IA }\end{array}$ & $\begin{array}{r}247.0 \\
964.0 \\
12.0 \\
6.5 \\
26.0 \\
8.8 \\
3.8 \\
23.0 \\
3.8 \\
1.8 \\
1.5\end{array}$ & $\begin{array}{l}93.0 \\
14.4 \\
80.0 \\
60.0 \\
34.0 \\
56.0 \\
66.0 \\
20.0 \\
49.0 \\
41.0 \\
58.0\end{array}$ & $\begin{array}{r}85.0 \\
6.4 \\
72.0 \\
52.0 \\
26.0 \\
48.0 \\
58.0 \\
12.0 \\
41.0 \\
33.0 \\
50.0 \\
\end{array}$ & $\begin{array}{r}0.963 \\
.999 \\
.972 \\
.983 \\
.994 \\
.985 \\
.980 \\
.998 \\
.988 \\
.992 \\
.984\end{array}$ & $\begin{array}{r}20.20 \\
6.16 \\
.84 \\
.33 \\
.67 \\
.42 \\
.22 \\
.28 \\
.15 \\
.06 \\
.07\end{array}$ \\
\hline Total or average & $1,298.0$ & 31.3 & 23.3 & 0.991 & 29.40 \\
\hline
\end{tabular}

'Based on discharge measurements by L. Willey at ES3 and includes corresponding estimates for the other three springs.

${ }^{2}$ Based on estimates by Lewis to include some unmeasured discharge. 
depth. Temperature at $15 \mathrm{~m}$ at sites where test wells are less than $15 \mathrm{~m}$ deep, was estimated using a leastsquares linear-regression correlation between temperatures at $10 \mathrm{~m}$ and $15 \mathrm{~m}$. The coefficient of determination for the linear regression was greater than 0.99 for each of three sets of measurements during 1972-74. The data and linear regression for the last set of measurements, in October 1972, are shown in figure 16.

The pattern of temperature at $15 \mathrm{~m}$ depth is shown in figure 14. The area of highest temperature is presumably along the Hot Creek gorge where the hot springs discharge into the creek. Highest measured temperatures are in two wells less than $0.6 \mathrm{~km}$ southeast of the gorge. The configuration of the isotherms suggests southeastward transport of heat by ground water mov- ing through aquifers below $15 \mathrm{~m}$ depth in the direction of the lateral hydraulic gradient, toward Lake Crowley. The pattern of two elongate lobes of high temperature, separated by a zone of much lower temperature shown in figure 14 differs from the pattern at a depth of $10 \mathrm{~m}$ inferred by Lachenbruch, Sass, Munore, and Moses (1976, fig. 1). Although the data points are too sparse to choose between the two isotherm configurations, we prefer the present interpretation, for two principal reasons. First, the configuration of the isotherms shown in figure 14 is most consistent with the pattern of shallow ground-water flow (fig. 10). According to our present interpretation, some of the thermal water that rises near the Hot Creek gorge does not discharge as springs in the gorge but mixes with

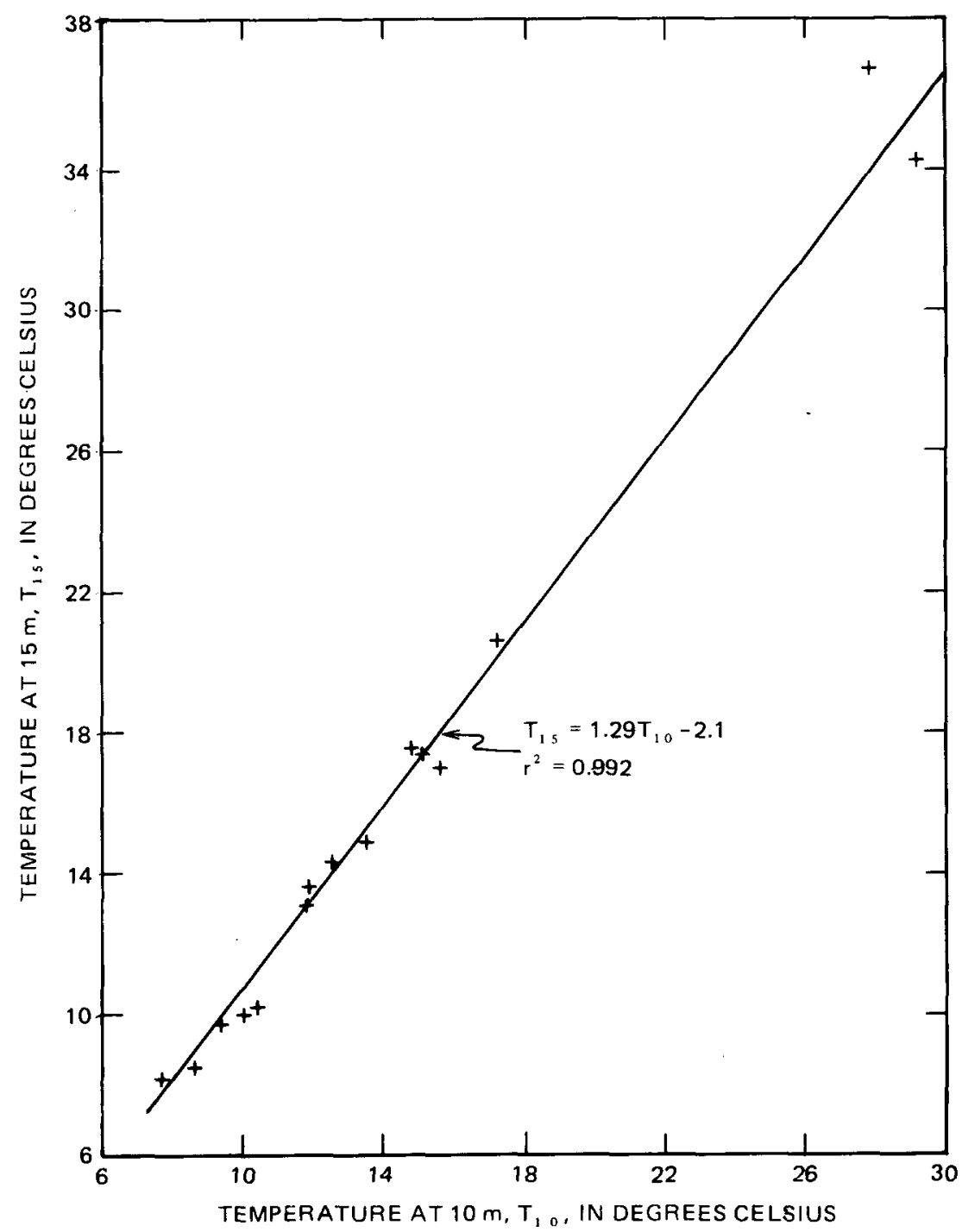

Figure 16.--Relation between temperatures at depths of $15 \mathrm{~m}$ and $10 \mathrm{in} \mathrm{Long} \mathrm{Valley}$ caldera, October 1974. Data from Lachenbruch, Sorey, Lewis, and Sass, 1976. 
shallow ground water and moves laterally toward Lake Crowley. As discussed in a later section, the zone carrying most of the hot water lies at depths about $100 \mathrm{~m}$. Second, a temperature survey at $1 \mathrm{~m}$ depth in 1972 utilizing additional data points (Lewis, unpub. data, 1973) showed approximately the same pattern as that in figure 14. Although the correlation of temperatures at $1 \mathrm{~m}$ with those at greater depths is not nearly as good as that of temperatures at $10 \mathrm{~m}$ and $15 \mathrm{~m}$ described above, we believe the pattern inferred from the $1-\mathrm{m}$ temperature data is a fairly reliable indication of the pattern at a depth of $15 \mathrm{~m}$.

As the second step in the calculation of near-surface conductive heat discharge, the temperature gradients derived from the measured and extrapolated temperatures at $15 \mathrm{~m}$ and the assumed land-surface temperature of $8^{\circ} \mathrm{C}$ were multiplied by an assumed average thermal conductivity of $2.0 \mathrm{mcal} /\left(\mathrm{cm} \mathrm{s} \cdot{ }^{\circ} \mathrm{C}\right.$ ) (Sass and others, 1974 , p. 29 and table 11) for the materials from 0 to $15 \mathrm{~m}$ to give conductive heat flow. Heat-flow values, in $\mu \mathrm{cal} /\left(\mathrm{cm}^{2} \mathrm{~s}\right)$ or heat-flow units (HFU), are shown in figure 15 . Because they are derived from the temperature at $15 \mathrm{~m}$, the heat flows define an areal pattern similar to that of the temperatures (compare figs. 14 and 15).

Much of the area having heat flow less than 2 HFU is affected by recharge of cold ground water. The area of high heat flow, especially above $20 \mathrm{HFU}$, is characterized by convective upflow of thermal water or by lateral advection of thermal water that has moved upward nearby.

To calculate the total near-surface conductive heat discharge in the caldera, heat discharge from the area between each pair of heat-flow isograms in figure 15 is computed as the product of the area and the geometric mean of the two isogram values. The heat discharges thus obtained are then added to obtain the total as shown in table 13 . The total area used is slightly greater than that of the caldera floor, because heat flows within the 10- and 20-HFU isograms southeast of the caldera, at Lake Crowley, are included. The total conductive heat flow, $3.5 \times 10^{7} \mathrm{cal} / \mathrm{s}$, represents all the geothermal heat leaving the caldera except that transported to the surface by spring flow or transported. beyond the perimeter of the caldera by ground-water flow into southern Lake Crowley.

ADVECTIVE HEAT DISCHARGE BY GROUND-WATER OUTFLOW TO LAKE CROWLEY.

The final element of heat discharge from the Long Valley caldera is the heat advected by:eastward and southeastward ground-water flow from the Hot Creek
TABLE 13.-Near-surface conductive heat discharge from Long Valley caldera (from heat-flow data shown in fig. 15)

\begin{tabular}{crcc}
\hline $\begin{array}{c}\text { Heat flow } \\
\text { (HFU) }\end{array}$ & $\begin{array}{c}\text { Area } \\
\left(\mathrm{km}^{2}\right)\end{array}$ & $\begin{array}{c}\text { Geometric-mean } \\
\text { heat flow } \\
\text { (HFU) }\end{array}$ & $\begin{array}{c}\text { Heat discharge } \\
\left(\times 10^{6} \mathrm{cal} / \mathrm{s}\right)\end{array}$ \\
\hline 60 & 9.5 & 69.30 & 6.6 \\
$40-60$ & 9.1 & 49.00 & 4.4 \\
$20-40$ & 28.3 & 28.30 & 8.0 \\
$10-20$ & 74.4 & 14.10 & 10.5 \\
$2-10$ & 95.2 & 4.47 & 4.3 \\
$<2$ & 232.4 & 0.50 & 1.2 \\
\hline
\end{tabular}

Total or

average

448.9

7.80

35.0

gorge thermal area into Lake Crowley south of the caldera margin. Warm bulges in the temperature profiles of four test wells, $\mathrm{CH}-3, \mathrm{CH}-5, \mathrm{CH}-7$, and $\mathrm{CH}-10$, indicate that most of the thermal ground water moving toward the lake is in an aquifer at depths above $100 \mathrm{~m}$ and ranging in thickness from about 23 to $46 \mathrm{~m}$. The heat advected to the lake by this ground-water flow is estimated as follows.

First, thermal ground-water outflow is considered as the flow across a vertical section of aquifer near the north shore of the southern part of the lake (line A-A' in fig. 17). The outflow is calculated as the product of the average hydraulic gradient normal to the transmitting section, the area of the section, and its average hydraulic conductivity at the prevailing temperature of the fluid $\left(50^{\circ} \mathrm{C}\right)$. The area of the transmitting section is the product of its length $(3.1 \mathrm{~km})$ and its average thickness $(32 \mathrm{~m})$, or $9.9 \times 10^{8} \mathrm{~cm}^{2}$. The average hydraulic gradient is calculated as the average of the two gradients of the water table shown in figure 17, or 0.0115 . The average hydraulic conductivity at the prevailing temperature of $50^{\circ} \mathrm{C}$ is assumed to be 9.3 $\mathrm{m}$ /day. This value is equivalent to a hydraulic conductivity of $4.5 \mathrm{~m} /$ day at the standard temperature of $60^{\circ} \mathrm{F}$ $\left(15.6^{\circ} \mathrm{C}\right)$, which is near the upper limit of values measured for core samples from the test wells (table 6 and Lewis, 1975, table 2). Estimated ground-water outflow is, therefore,

$$
Q=A I K=120 \mathrm{~L} / \mathrm{s}
$$

where $A=$ area of transmitting section, $I=$ hydraulic gradient, and $K=$ hydraulic conductivity.

The heat advected by this outflow is calculated from equation (1) as $5.0 \times 10^{6} \mathrm{cal} / \mathrm{s}$, on the basis of an annual average ambient temperature at land surface of $8^{\circ} \mathrm{C}$ and an average discharge temperature of $50^{\circ} \mathrm{C}$. 
TOTAL HEAT DISCHARGE

The total discharge of geothermal heat from the Long Valley caldera is summarized below:

Convective heat discharge by springflow

Near-surface conductive heat discharge

Advective heat discharge by ground-water outflow to Lake Crowley

Total heat discharge

Heat discharge $\left(\times 10^{7} \mathrm{calls}\right)$

2.9

3.5

$\underline{.5}$

6.9

This estimate of heat discharge exceeds the previous estimates listed in table 11, except for that by White (1965), at least in part because most of the earlier estimates do not include all the effects of heat conduction. The close agreement with White's estimate is partly

coincidental with offsetting of differences in assumptions. Sources of error in the present estimate include errors inherent in the simplified assumptions and errors or deficiencies in the data. Previous estimates of convective heat discharge are limited by various assumptions in the geochemical models, which are not yet verified by deep-test-hole data, but which apparently lead to reasonable heat-flow estimates. Taking into account all the known sources of error, the most likely value of the total natural heat discharge is within the range $5-10 \times 10^{7} \mathrm{cal} / \mathrm{s}$. Our estimate of $6.9 \times$ $10^{7} \mathrm{cal} / \mathrm{s}$ is equivalent to $15 \mathrm{HFU}$ integrated over the $449-\mathrm{km}^{2}$ area of the caldera floor. In the numerical simulations discussed in the following section, this heat flow represents an important constraint on the required depths of fluid circulation.

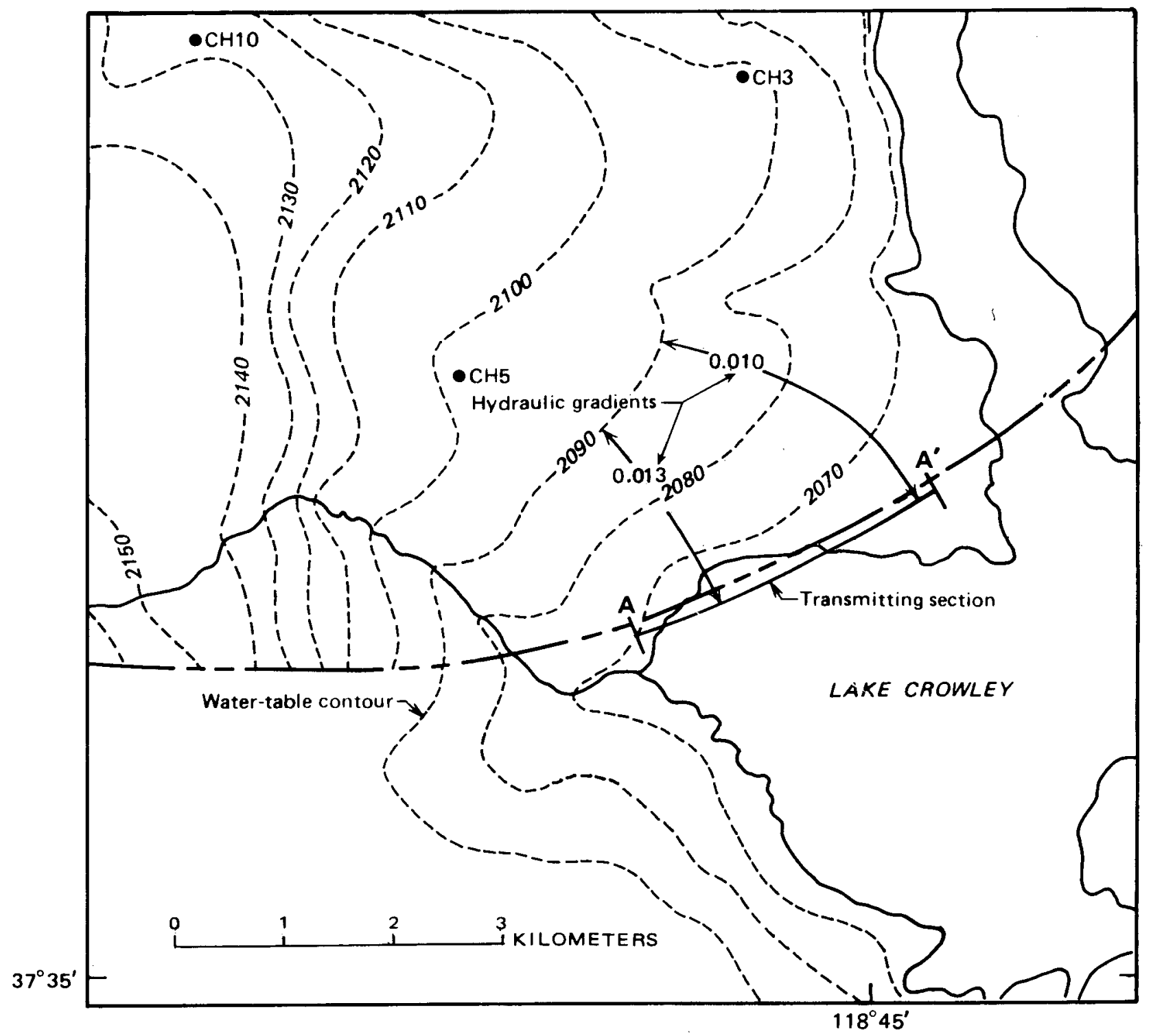

Figure 17.-Map showing elements used in estimate of thermal ground-water flow into Lake Crowley. 


\section{SOURCES OF HEAT}

The results of several investigations suggest that a residual magma chamber underlies the west half of Long Valley caldera at the present time. The heat-flow anomaly beyond the west rim and implications of resupply of magma from deep crustal sources to sustain molten material over the 2-m.y. eruptive history of the area were noted above. In discussing the magmatic history, Bailey, Dalrymple, and Lamphere (1976) explain the concentric zonation of the postcaldera eruptives as a consequence of progressive downward crystallization of a magma chamber that was vertically zoned from rhyolite in its upper part to rhyodacite in its lower part. On the basis of structural analysis of the resurgent dome, they suggest that at the close of resurgence about 0.6 m.y. ago, the top of the Long Valley magma chamber had risen to at least a $5-\mathrm{km}$ depth and possibly to 2 or $3 \mathrm{~km}$. By about $0.2 \mathrm{~m}$.y. ago, lateral encroachment of basalt dikes on the chamber suggests that it had congealed inward and downward $4 \mathrm{~km}$ to a depth of 6 to $9 \mathrm{~km}$.

Teleseismic and seismic refraction studies (Steeples and Iyer, 1976; Hill, 1976) indicate that an anomalously hot or partly molten mass persists below 6 to 8 $\mathrm{km}$ under the western caldera. Gentle gravity gradients outside, but sloping toward, the caldera indicate a low-density mass at depths of 8 to $16 \mathrm{~km}$ and large enough to constitute an anomaly of about $10 \mathrm{mgal}$ (Kane and others, 1976a, b). Magnetic contrasts within the caldera (lower in the west half) are best explained in major part by extensive hydrothermal alteration of the Bishop tuff in and near the resurgent dome (Williams, 1976).

A simplified model which emerges from the above results involves a magma chamber at a depth of 6 to 8 $\mathrm{km}$, which has underlain the west half of the caldera for at least the last $0.3 \mathrm{~m} . \mathrm{y}$. A period of $0.3 \mathrm{~m} . \mathrm{y}$. is sufficient for equilibration of an overlying conductive regime. This is, of course, an oversimplification: young rhyolitic rocks of the Inyo Domes, which erupted in the west moat as recently as 700 yrs ago, appear to be a mixture of magmas from the residual. Long Valley chamber and from the younger Mono Craters magma system farther to the north. This and other recent volcanic activity suggest that localized areas of relatively shallow hot rock may underly the west moat; their presence may be masked by the flow of cold ground water originating near the west rim. However, if the hydrothermal system has persisted for a period of 0.3 m.y., as suggested by Bailey, Dalrymple, and Lanphere (1976), the paucity of evidence for hydrothermal activity directly associated with any of the postcaldera eruptive rhyolites and estimates of present-day heat discharge imply that the hydrothermal system is re- lated to the main magma chamber, which is a deeper and larger heat source.

\section{ANALYSIS OF CONCEPTUAL MODEL OF HYDROTHERMAL SYSTEM DESCRIPTION OF CONCEPTUAL MODEL}

On the basis of geologic, hydrologic, geophysical, and geochemical characteristics of the Long Valley caldera discussed previously, we have developed a generalized conceptual model of the hydrothermal system. In many respects the model is oversimplified, and should not be considered a unique representation of the caldera's hydrothermal system. Although the gross features of the model are consistent with known constraints, additional data from deep test holes would add considerably to the level of detail with which the system could be modeled. Indeed, results obtained from Republic Geothermal's recent deep test well caused a significant revision of our original model in regard to hydrothermal conditions beneath the eastern part of the caldera. With these limitations in mind, we have analyzed heat and fluid flow in the model, using numerical simulation techniques, in order to demonstrate the capabilities of this approach, to provide preliminary quantification of the relationship between heat and fluid flow, and to gain insights as to the hydraulic characteristics of the hydrothermal reservoir.

The conceptual model is illustrated in figure 18 . The model is three-dimensional, includes the area within the topographic boundary of the caldera floor, and extends to a depth of $6 \mathrm{~km}$. For numerical simulation, the caldera rocks are divided into 5 horizontal layers, corresponding in general to the major rock units identified by the seismic refraction study (Hill, 1976), the geological investigations (Bailey, and others, 1976), and the calculations of depths of fill presented previously. The upper layer, $1 \mathrm{~km}$ thick, corresponds to the postcaldera sedimentary and volcanic rocks having low $\mathrm{P}$-wave velocities (from 1.5 to $3.4 \mathrm{~km} / \mathrm{s}$ ). This layer includes the shallow ground-water subsystem described earlier. Layer 2 corresponds to the densely welded Bishop Tuff and forms a continuous layer over the area of the caldera having a seismic P-wave velocity of 4.0 to 4.4 $\mathrm{km} / \mathrm{s}$. Layer 3 extends to a depth of $3 \mathrm{~km}$ and includes densely welded Bishop Tuff, rhyolite of Glass Mountain, and other precaldera sediments and volcanics, and, in parts of the caldera, probably some basement rocks. Layers 2 and 3 correspond approximately to the deep ground-water subsystem described earlier. Layers 4 and 5 extending to $6 \mathrm{~km}$ are considered as impermeable but thermally conductive granitic and metasedimentary basement rocks. Two layers are used in this depth interval to allow more accurate numerical heat-flow simulation. A magma chamber 
below $7 \mathrm{~km}$ under the western half of the caldera, as suggested by the seismic, teleseismic, and heat-flow studies discussed previously, is simulated by a constant (with time) but areally variable temperature distribution at the base of the model. The adequacy of this simplification is discussed later in this section.

The hydraulic and thermal properties of each layer in the model are listed in table 14. Layer 1 is considered an impermeable cap except along parts of the caldera rim, where recharging ground water moves downward along the ring fault, and in the Hot Creek gorge area, where hot water flows upward along faults and discharges in the springs in the gorge. We assume that, although ground-water flow in the shallow sedimentary and volcanic rocks may have significant localized effects on the surficial thermal regime, flow in this layer can be considered as separated hydraulically from the hydrothermal reservoir (the deep subsystem), except as noted. Extremely low values of vertical hydraulic conductivity measured in cores from the upper $300 \mathrm{~m}$ tend to support this assumption, although the existence of slow vertical flows through this layer, which may significantly affect the temperature and heat-flow regime at depth, cannot be discounted, particularly in areas of active faulting. Limitations of computing times and the lack of adequate hydrologic data require that the shallow ground-water subsystem be neglected in this analysis, except as a source, or recharge along parts of the caldera rim.

The hydrothermal reservoir is assumed to exist in

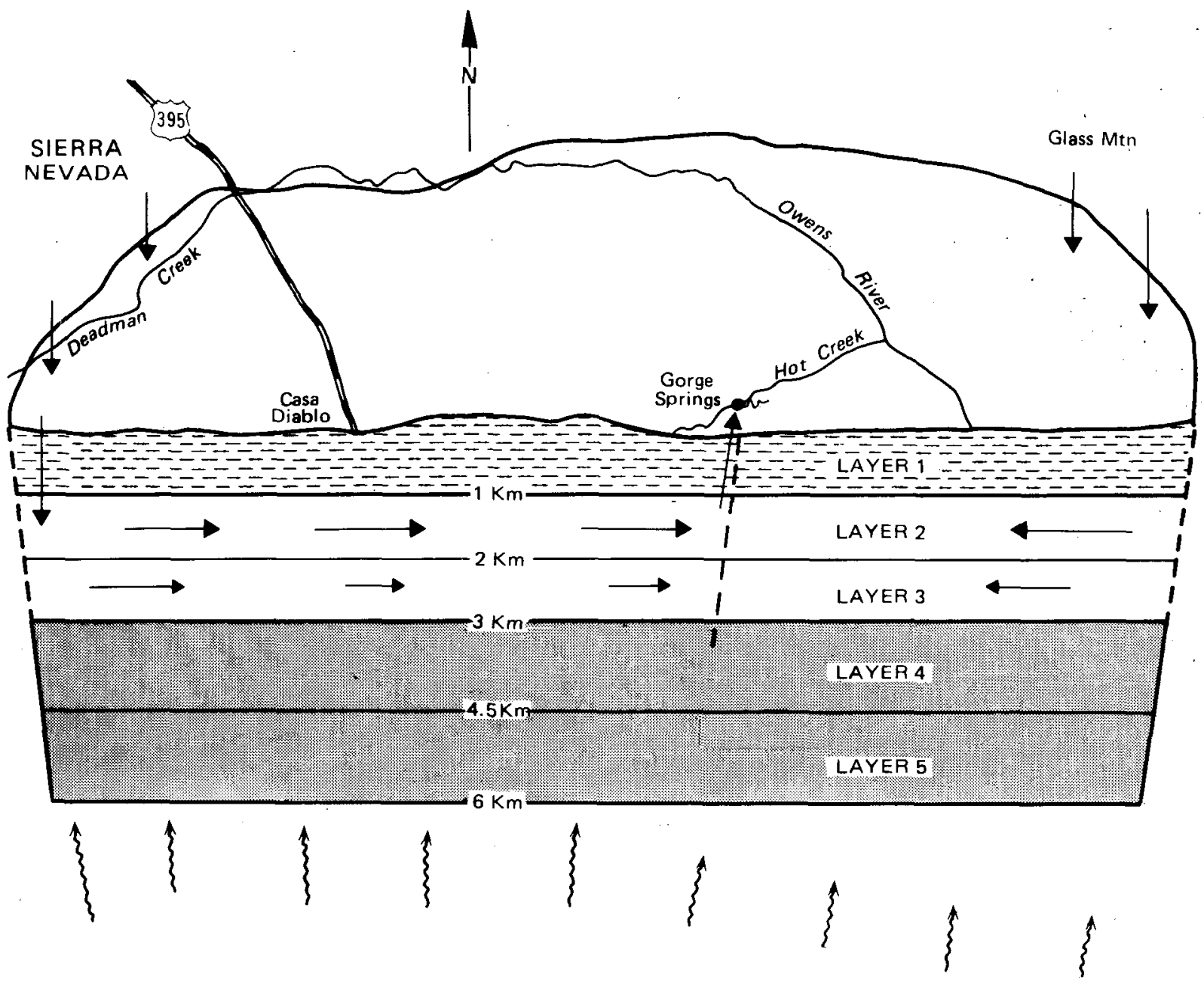

Figure 18.-Block diagram showing conceptual model of Long Valley hydrothermal system. Model consists of 5 horizontal layers having properties listed in table 15. Patternless layers between depts of 1 and $3 \mathrm{~km}$ represent the hydrothermal reservoir in fractured, densely welded Bishop Tuff. Recharge to reservoir is by way of caldera ring fault in the west and northeast. Discharge is by way of faults and fractures to springs in Hot Creek gorge. Straight arrows indicate ground-water flow, wavy arrows indicate heat flow. Vertical to horizontal exaggeration approximately 1.6 to 1 . 
TABLE 14.-Hydraulic and thermal properties for Long Valley hydrothermal model

\begin{tabular}{|c|c|c|c|c|c|}
\hline Layer & $\begin{array}{c}\text { Thermal } \\
\text { conductivity } \\
\text { (mcal/)cms } \cdot{ }^{\circ} \mathrm{C} \text { ) }\end{array}$ & $\begin{array}{c}\text { Heat } \\
\text { capacity } \\
\left.\left(\mathrm{cal} / \mathrm{cm}^{3}{ }^{\circ} \mathrm{C}\right)\right)\end{array}$ & $\begin{array}{c}\text { Intrinsic } \\
\text { permeability } \\
\left(\mathrm{m}^{2} \times 10^{-12}\right)\end{array}$ & $\begin{array}{c}\text { Vertical } \\
\text { compressibility } \\
\left(\mathrm{m}^{2} / \mathrm{N}\right)\end{array}$ & Porosity \\
\hline 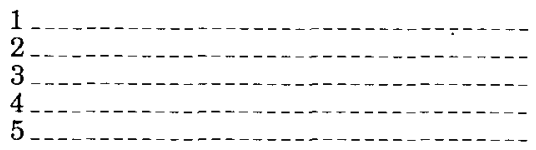 & $\begin{array}{l}2 \\
5 \\
5 \\
6 \\
6\end{array}$ & $\begin{array}{r}0.54-0.58 \\
.54-.58 \\
.54-.58 \\
.54-.58 \\
.54-.58\end{array}$ & $\begin{array}{c}0 \\
0.03-0.35 \\
.03-.35 \\
0 \\
0\end{array}$ & $\begin{array}{r}{ }^{1} 10.0 \times 10^{-10} \\
21.0 \times 10^{-10} \\
1.0 \times 10^{-10} \\
1.0 \times 10^{-10} \\
1.0 \times 10^{-10}\end{array}$ & $\begin{array}{r}0.35 \\
.10 \\
.05 \\
.05 \\
.05\end{array}$ \\
\hline
\end{tabular}

${ }^{1}$ Estimated at 3 times compressibility of sand (Jacob, 1950, p. 334) because of abundance of tuffaceous and lacustrine deposits.

${ }^{2}$ Estimated at $1 / 3$ compressibility of sand because of induration.

the fractured, welded Bishop Tuff in layers 2 and 3 of the model. The possibility that the main aquifer is below the Bishop Tuff in precaldera sediments, tuffs, and lava flows should be recognized. Because the average thickness of the welded Bishop Tuff is about 1.4 $\mathrm{km}$, layer 3 in the model could be considered as including such an aquifer. The effect of the depth of fluid circulation on temperature and heat-flow distributions was evaluated by simulating flow in layer 2 only, in layer 3 only, and finally in both layers 2 and 3 . In each case, ground-water flow is from the higher altitudes along the west and northeast rims toward discharge areas in Hot Creek gorge and along the southeast caldera rim. Additional driving force causing flow is provided by density differences between hot and cold parts of the flow system.

In some model runs, pressures based on altitudes of the water table in recharge and discharge areas (fig. 10) were specified and reservoir permeability was adjusted to yield the desired mass flux of water through the reservoir. Similar results were obtained by specifying recharge rates and pressures in discharge areas, and adjusting permeability until pressures in recharge. areas matched the observed water-table altitudes. Recharge rates were determined by distributing the total mass flux over the areas of the recharge nodes, with weighting according to water-table altitudes. These procedures yield values for the product of effective reservoir permeability times thickness; the ranges in permeability values listed in table 15 represent results from three cases of assumed reservoir permeability distributions, as discussed below. The principal limitation of this procedure is the uncertainty as to pressure losses in the upflow and downflow fault conduits.

\section{NUMERICAL SIMULATION}

To permit numerical simulation of heat and fluid flow, each layer of the model is subdivided into 82 grid blocks or nodes along land-net lines (fig. 19). Finer nodal spacing is used near the discharge areas. Thermal water is assumed to discharge only over the surface of the node that includes the springs in Hot Creek gorge, and through the southeast rim of the caldera. Only minor differences in computed distributions of pressure and temperature would be expected if a more detailed distribution of hot-water discharge were modeled, because approximately 80 percent of the surface discharge from the thermal reservoir is through the springs in the gorge (Sore and Lewis, 1976).

The equations and solution procedure used in this study are described in detail by Sorey (1975). The flow equation is

$$
\nabla \cdot\left[\bar{\rho} \frac{\mathrm{k}}{\mu}\left(\Delta \mathrm{P}-\overline{\rho_{g}}\right)\right]=C \frac{\partial P}{\partial t}
$$

where

$\rho=$ fluid density, $k=$ intrinsic permeability, $\mu=$ dynamic viscosity, $P=$ fluid pressure,$\overline{\mathrm{g}}=$ gravitational acceleration vector, $C=$ fluid-rock compressibility, and $t=$ time.

Equation 2 is based on conservation of mass and Darcy's law for nonisothermal fluid flow in porous media. An assumption inherent in this formulation is that fluid flow in the hydrothermal system, although probably controlled locally be permeable zones along faults, can best be described in large scale as a porous medium in which permeability is distributed effectively throughout.

The energy equation is

$$
\nabla \cdot\left[K_{m} \Delta T\right]-\rho c \bar{v} \cdot \Delta T=(\rho c)^{\prime} \frac{\partial T}{\partial t}
$$

where

$K_{m}=$ rock-fluid thermal conductivity, $T=$ rockfluid temperature, $\bar{v}=$ Darcy velocity vector, $c=$ fluid specific heat at constant volume, and $(\rho c)^{\prime}=$ rock-fluid heat capacity.

Equation (3) accounts for conductive and convective 
transfer of heat under steady-state and transient conditions. We assume that thermal equilibrium exists between fluid and solid phases at points of contact and that heat transfer by hydrodynamic dispersion can be neglected in the type of problem considered here (Mercer and others, 1975, p. 2618). Temperaturedependent parameters, $\mu$ and $c$, in equations (2) and (3) were evaluated from tabulated data (Dorsey, 1968)

The equation of state relating fluid density to temperature is

$$
\rho=\rho_{o}\left[1-\beta\left(T-T_{o}\right)-\Upsilon\left(T-T_{o}\right)^{2}\right]
$$

where

$\rho_{o}=$ fluid density at reference temperature $T_{o}, \beta=$ thermal expansivity, and $Y=$ coefficient for second-order fit. Density variations with pressure are neglected.
Simultaneous solutions to the flow and energy equations were obtained by an integrated finite-difference method involving iterative solutions at selected time steps for pressure, temperature, and velocity fields. This numerical procedure offers considerable advantages over standard finite-difference methods in terms of reduced computing times and nodal requirements (Narasimhan and Witherspoon, 1976). The time step used to solve the energy equation is continuously increased by a factor between 1 and 2 , with the limitation that the maximum change in nodal temperatures per time step be less than about 10 percent of the maximum total change expected in the system. Because the response times for pressure changes are much smaller than for temperature changes, the flow system essentially equilibrates to a quasi-steady state within each thermal time step. For a simulation period of 35,000 years, approximately 50 thermal time steps

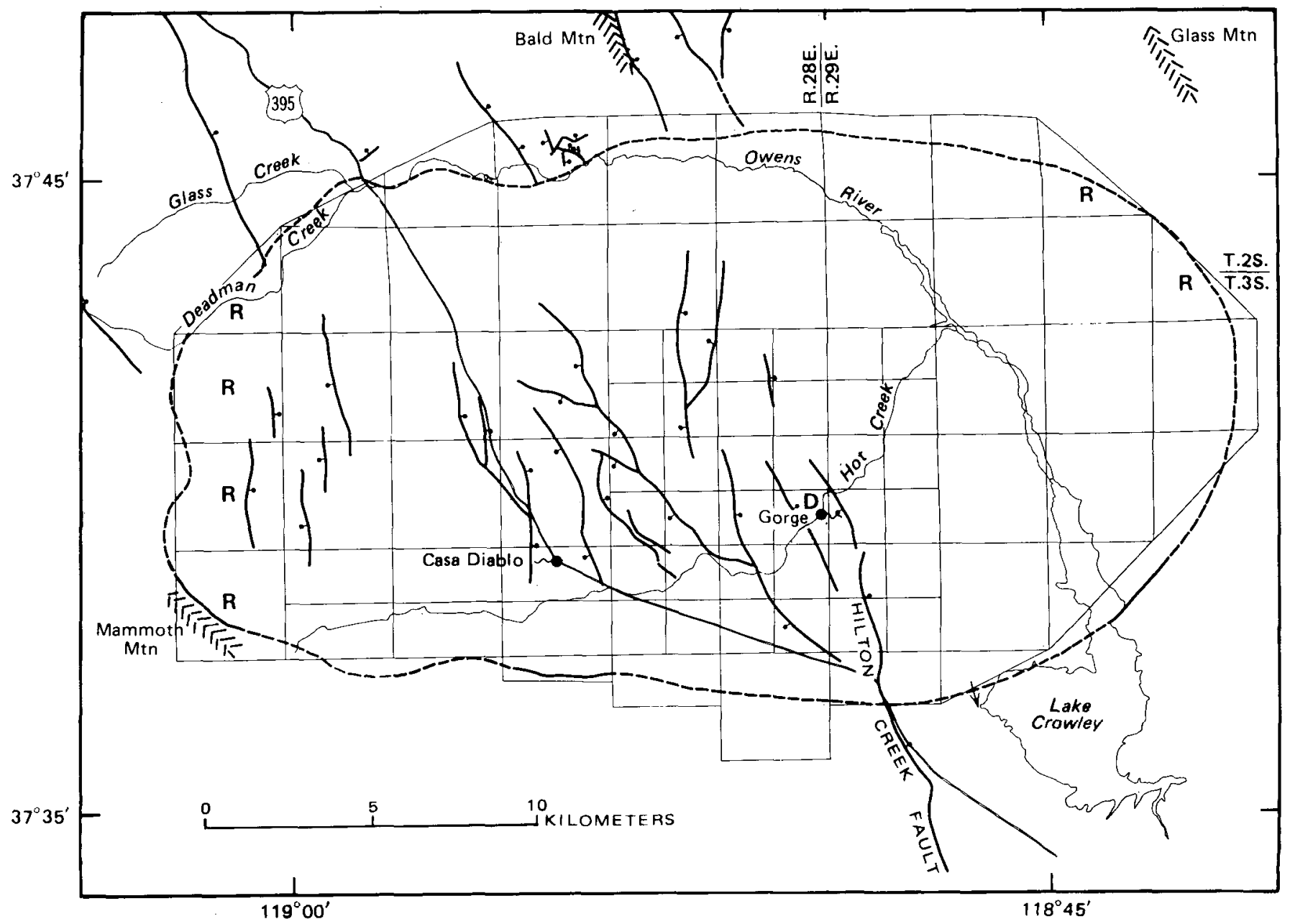

FIGURE 19.-Sketch map of Long Valley caldera showing nodal configuration for numerical simulation of hydrothermal system with uniform reservoir permeability distribution (case $A$ ). $R$ denotes recharge node; $D$ denotes discharge node covering springs in Hot Creek gorge. Principal faults shown as solid heavy lines with ball on downthrown side. Arrow denotes ground-water discharge at depth through southeast rim. 
were used; for a 350,000-year simulation, approximately 70 time steps were required.

As indicated in figure 19 , by the nodes marked $R$, recharge water enters the upper layer of nodes along the caldera rim. The centers of the rim nodes correspond generally to the caldera ring fault which is assumed to provide conduits for downflow to the hydrothermal reservoir. The rationale for simulating recharge only around the west and northeast rims involves several factors. First, isotopic evidence indicates that meteoric water from the west rim is the dominant source of the hot-water component in the thermal springs. Second, water-table altitudes are highest around the west rim (fig. 10), and cold, isothermal temperature profiles are observed in core holes drilled in the west moat (figs. 13 and 14). On the basis of data from the 2.11-km-deep test well (pl. 1, well 66-29), water in the deep ground-water subsystem under the eastern part of the caldera is isotopically similar to meteoric waters from the northeast rim. This similarity and the nature of the temperature profile observed in the deep well suggest that in addition to the easterly flow of hot water from the west rim, there is a flux of cooler water moving through the welded Bishop Tuff east of Hot Creek, the source of which is presumed to be recharge around the northeast rim. However, in preliminiary model simulations which permitted recharge through all the rim nodes by assigning to them a nonzero permeability and connecting them at the land surface to nodes held at constant pressure based on corresponding water-table altitudes, upflow occurred along the north, south, and east rims. Thus for deep recharge from the northeast rim to occur, artesian heads well above water-table altitudes would have to exist on the flanks of Glass Mountain. Additional water-level data are required to confirm this possibility.

The recharge rate from the northeast rim was arbitrarily set at about one-third of the flux from the west rim; this resulted in reservoir temperatures under the eastern caldera which agree with those observed in the deep test well. Simulation of subsurface discharge through the southeast rim provides the outlet for most of the northeast-rim inflow. The latter would otherwise have to discharge in the springs along Hot Creek gorge. Mixing of these waters would result in considerably cooler reservoir temperatures beneath Hot Creek gorge than in the numerical simulations discussed below. The geochemical evidence discussed previously, particularly the analysis by Fournier, Sorey, Mariner, and Truesdell (1976), indicates that such deep mixing does not occur. Permeable channels for the southeast rim outflow, which was modeled as leaving the reservoir through the caldera wall, could be provided by the Hilton Creek fault or possibly by con- cealed faults farther to the east (fig. 19). Additional subsurface information would be required to establish the existence and location of such outflow channels.

\section{HYDRAULIC CHARACTERISTICS}

Ground-water flow in the hydrothermal model between recharge and discharge areas is simulated trhough a horizontal layer of permeable rock from 1 to $2 \mathrm{~km}$ thick in layer 2 and/or layer 3 . The permeability needed to obtain the observed discharge of hot water can be considered an effective permeability which should be useful in analyzing reservoir response to development. A similar modeling effort for the hot-water reservoir at Wairakei, New Zealand, yielded temperature and pressure patterns that correlated well with observed response prior to initiation of two-phase conditions in the reservoir (Mercer and others, 1975). However, where faults and fractures are primarily responsible for the effective reservoir permeability, an individual well drilled into the reservoir may encounter considerably larger or smaller permeabilities than those indicated by the model simulation.

In figure 19, northwest-trending faults, some of which probably are extensions of the Hilton Creek fault, generally traverse the resurgent dome in the central part of the caldera. In the west moat, a group of north-trending faults are alined with postcaldera extrusive rocks $(<0.15$ m.y. old) extending from Mammoth Mountain north toward the Mono Craters. Fractures in the welded tuff associated with these major faults, as well as other faults not delineated at the land surface, are considered to provide the major channels for flow in the hydrothermal sytem.

Some justification for assuming no hydraulic connection between the upper and lower ground-water subsystems (except along the ring fault) is that secondary fracture permeability would be less likely to remain effective in the poorly indurated deposits overlying the Bishop Tuff. The occurrence of present-day hot springs along active faults, however, indicates that where poorly indurated deposits are altered and cemented, they can and do have secondary permeability. The apparent lack of faulting in the east part of the caldera (with the exception of the ring fault) need not preclude permeable zones in the Bishop Tuff in that area which could also result from brecciated zones between two major cooling units identified within the Bishop Tuff southeast of the caldera (Sheridan, 1968).

Three cases of reservoir permeability distribution are considered. Case A, referred to as the continuous reservoir (fig. 19), postulates a uniform permeability over the area of the caldera. In case B, referred to as the fault-zone reservoir (fig. 20), the northwesttrending fault zone in the central part of the caldera is 
considered as the only permeable zone within the Bishop Tuff. The volume of permeable rock in the fault-controlled rservoir is assumed to be approximately 40 percent of that in the continuous-reservoir model. Case $\mathrm{C}$, called the low-permeability-block reservoir, is similar to case A except for a zone of lower permeability (100 times lower than the remainder of the reservoir) between the west moat and the Casa Diablo Hot Springs area, as shown in figure 21. The rationale for case $\mathrm{C}$ involves the consideration that temperatures above $200^{\circ} \mathrm{C}$ are indicated geochemically in the reservoir underlying the Casa Diablo Hot Springs area, as discussed in the next section.

For Cases $\mathrm{A}$ and $\mathrm{C}$, numerical computations were made for mass fluxes of $190 \mathrm{~kg} / \mathrm{s}, 250 \mathrm{~kg} / \mathrm{s}$, and $300 \mathrm{~kg} / \mathrm{s}$ recharging in the west rim and discharging in Hot Creek gorge, and $110 \mathrm{~kg} / \mathrm{s}$ recharging in the northeast rim and discharging through the southeast rim. For case B, a flux of $250 \mathrm{~kg} / \mathrm{s}$ recharging in the north rim and discharging in the gorge was simulated, with no discharge through the southeast rim.

In table 15, values of intrinsic permeability obtained in the model simulations are compared with values from laboratory tests on Long Valley cores, with values for ash-flow tuffs at the Nevada Test Site (Keller, 1960; Winograd and others, 1971), and with values for pumice breccia and vitric tuff of the Wairora aquifer in New Zealand (Mercer and others, 1975). The Long Valley model results shown are for a mass flux of $250 \mathrm{~kg} / \mathrm{s}$ discharging in the gorge.

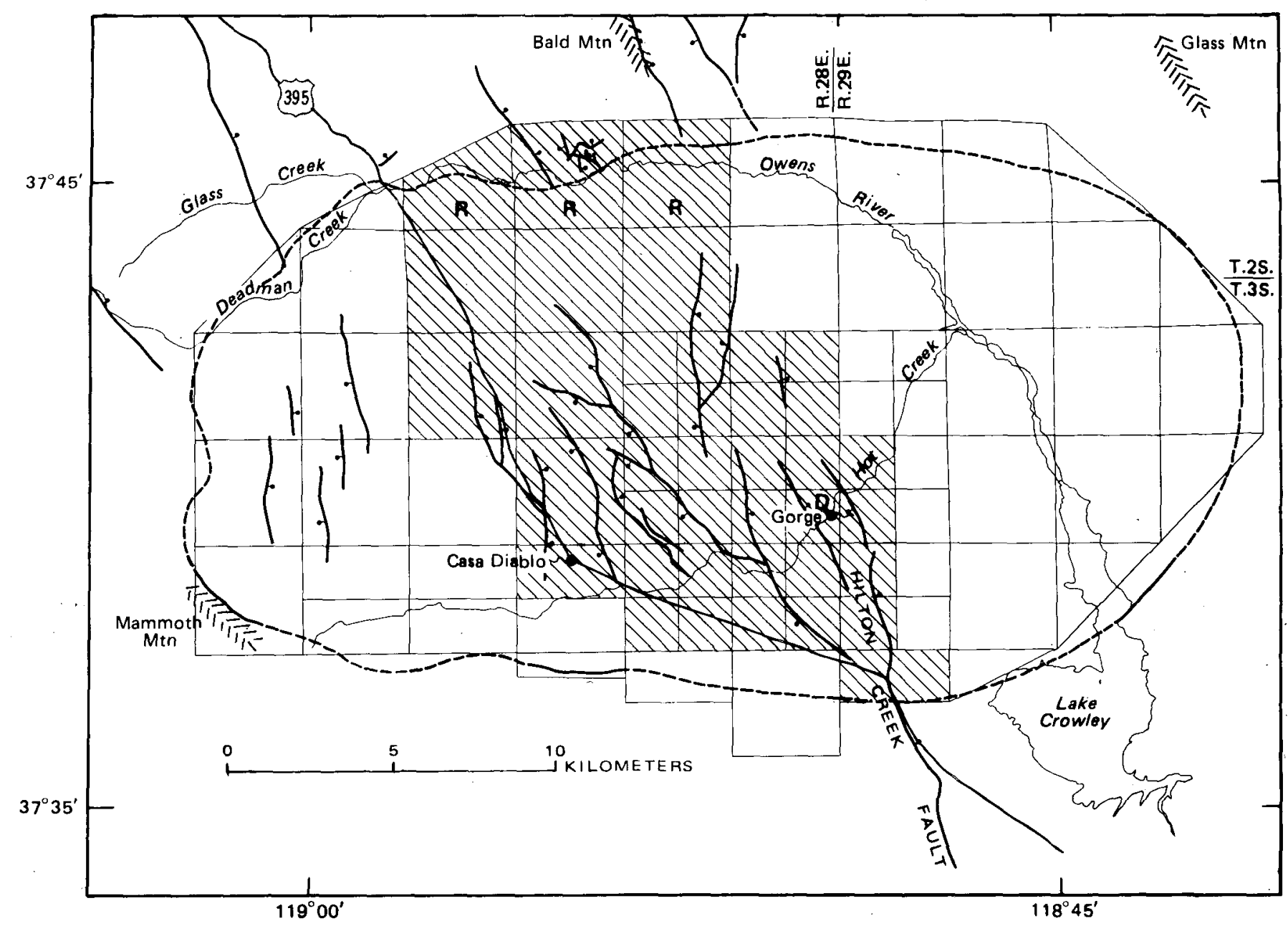

FIGURE 20.-Sketch map of Long Valley caldera showing nodal configuration for numerical simulation of hydrothermal system with fault-zone reservoir permeability distribution (case B). Permeability of nodes outside hatch area set to zero. $R$ denotes recharge nodes, $D$ denotes discharge node covering springs in Hot Creek gorge. 
TABLE 15.-Intrinsic-permeability data from Long Valley model and other studies

\begin{tabular}{lcc}
\hline \multicolumn{1}{c}{ Data source } & $\begin{array}{c}\text { Reservoir } \\
\text { thickness (km) }\end{array}$ & $\begin{array}{c}\text { Permeability } \\
\text { (millidarcys) }\end{array}$ \\
\hline $\begin{array}{l}\text { Continuous reservoir (case A) } \\
\text { Fault-controlled reservoir (case B) }\end{array}$ & 1 & 30 \\
$\begin{array}{l}\text { Low-permeability-block } \\
\quad \text { reservoir (case C) }\end{array}$ & 1 & 350 \\
$\begin{array}{l}\text { Wairakei model } \\
\text { Long Valley cores }\end{array}$ & 1 & 150 \\
NTS ash-flow tuffs & & 100 \\
NTS welded tuff $^{3}$ (fracture) & $0.4-0.85$ & $0.0005-180.0$ \\
\end{tabular}

${ }^{1}$ This value applies to west three-fifths of caldera; permeabitity equaled $30 \mathrm{md}$ in eastern two-fifths.

${ }^{2}$ Wairora aquifer consisting of pumice breccia and vitric tuffs as modeled by Mercer, Pinder, and Donaldson (1975).

${ }^{3}$ Includes only data from cores of altered rock, flow rocks, and nonwelded tuffs.

${ }^{4}$ Oak Springs Formation (Keller, 1960).

5Winograd, Thordarson, and Young (1971).
Permeabilities computed from the model are inversely proportional to the assumed reservoir thickness. The range for a reservoir $1 \mathrm{~km}$ thick is from 30 millidarcys (md) for the continuous reservoir to $350 \mathrm{md}$ for the fault-zone reservoir. Corresponding values of hydraulic conductivity, which are related to intrinsic permeability as

$$
K=\frac{k}{\mu} \rho g
$$

vary with temperature within the reservoir. At a temperature of $100^{\circ} \mathrm{C}$, hydraulic conductivity for the continuous reservoir is $0.09 \mathrm{~m} / \mathrm{day}$, compared to $1.0 \mathrm{~m} /$ day for the fault-zone reservoir. The reservoir temperature distributions for which the results in table 16 were obtained are discussed in the next section.

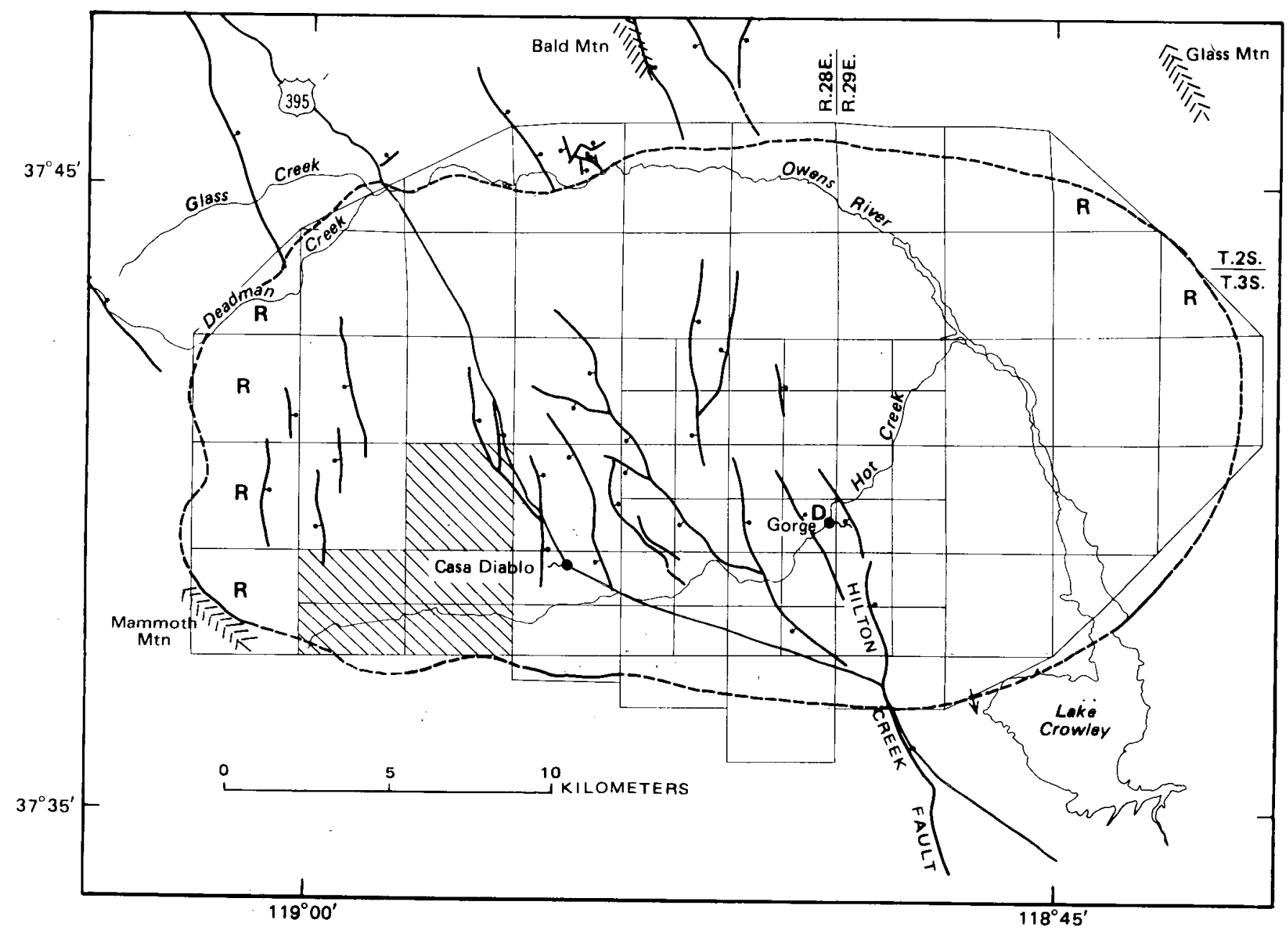

FIGURE 21. Sketch map of Long Valley caldẹa showing nodal configuration for numerical simulation of hydrothermal system with lowpermeability-block reservoir permeability distribution (case C). Permeability of hatched reservoir nodes equal to $10-{ }^{2}$ times permeability of other reservoir nodes. $\mathrm{R}$ denotes recharge nodes, $\mathrm{D}$ denotes discharge node covering springs in Hot Creek gorge. Arrow denotes discharge at depth through Southeast rim. 
The effective permeability of $100 \mathrm{md}$ used in the Wairakei model (Mercer and others, 1975) is within a factor of three of each of the Long Valley model cases. This suggests that the results for the Long Valley model are reasonable, but does not show which of the three cases is most likely. Thermal consideration discussed in the next section of the report indicate that depths of fluid circulation required for the fault-zone model to obtain reservoir temperatures in excess of $200^{\circ} \mathrm{C}$ are considerably greater than for the other two cases.

Permeabilities measured on all cores from the upper $300 \mathrm{~m}$ of Long Valley fill range from approximately $10^{-4}$ md to $10^{4} \mathrm{md}$. As shown in table 6 , the highest values were obtained on samples of sandy or gravelly tuffaceous sediments, and the lowest values were ob- tained from hydrothermally altered tuffs and sediments. In table 16, the range in permeability for cores of altered rock, flow rocks, and nonwelded tuffs are close to or below the range of effective permeability from the model simulations, as are values reported by Keller (1960) for ash-flow tuff at the Nevada Test Site (NTS). In contrast, permeabilities obtained from well tests in fractured welded tuff at NTS (Winograd and others, 1971) are considerably greater than the permeabilities indicated by the model. This supports the concept that the effective permeability obtained with the numerical model represents an integration of the effects of fracture permeability over the volume of the welded-tuff reservoir.

To illustrate circulation patterns in the simulated reservoir, pressures at each node were converted to

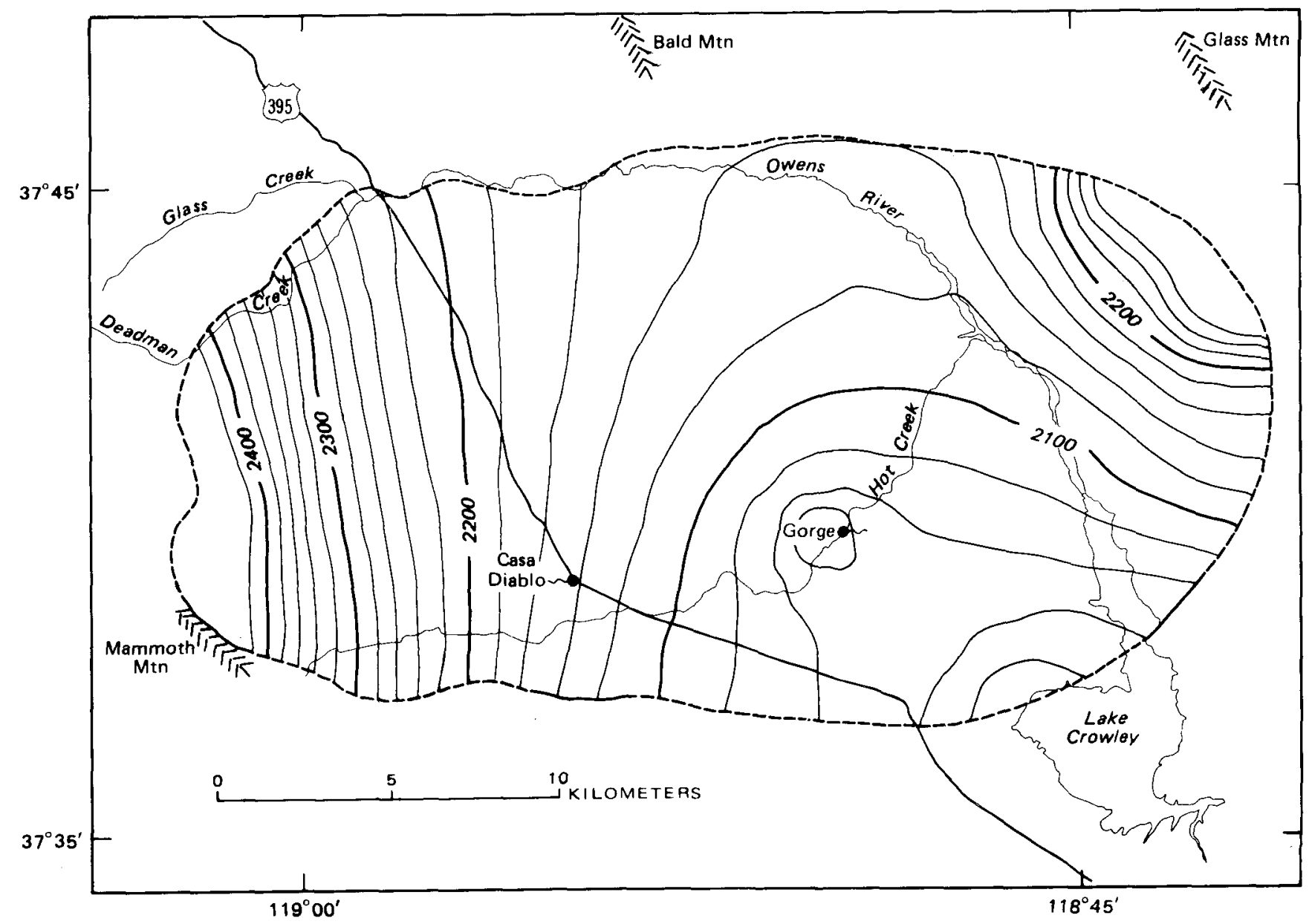

FIGURE 22.-Sketch map of Long Valley caldera showing equivalent hydraulic head in reservoir from 1 to $2 \mathrm{~km}$ deep from case A with uniform reservoir permeability of 30 millidarcys, hot-spring discharge of $250 \mathrm{~kg} / \mathrm{s}$ in Hot Creek gorge, southeast-rim outflow of $110 \mathrm{~kg} / \mathrm{s}$, and simulation period of 35,000 years. Contours of equivalent hydraulic head in meters above mean sea level. Interval $20 \mathrm{~m}$. 
equivalent or "cold water" heads using the relationship

$$
H_{o}=P / \rho_{o} g+z
$$

where $\rho_{0}=$ fluid density at reference temperature $\left(10^{\circ} \mathrm{C}\right)$ and $z=$ altitude of node above sea level. This also permits comparisons of equivalent head distributions with the water-table map (fig. 10). Reservoir head distribution in layer 2 at $1.5-\mathrm{km}$ depth for the continuous-reservoir and low-permeability-blockreservoir cases are shown in figures 22 and 23 . Both cases show the predominant eastward flow toward the Hot Creek gorge area and the effects of recharge from the Glass Mountain area and discharge through the southeast rim. Comparison of figures 22 and 23 indicates the barrier effect of the low-permeability block west of the Casa Diablo area, with the bulk of circulation passing north of the barrier. Reservoir permeability in case $\mathrm{C}$ was about 50 percent greater in the western three-fifths of the caldera than in the continuous-reservoir case A in order to yield the same flow. The permeability assigned to the low-permeability block was two orders of magnitude lower than elsewhere in the reservoir.

Comparisons of reservoir head distribution in figures 22 and 23 with the head distributions in the shallow ground-water system in figure 10 help to clarify some of the hydraulic characteristics of the hydrothermal

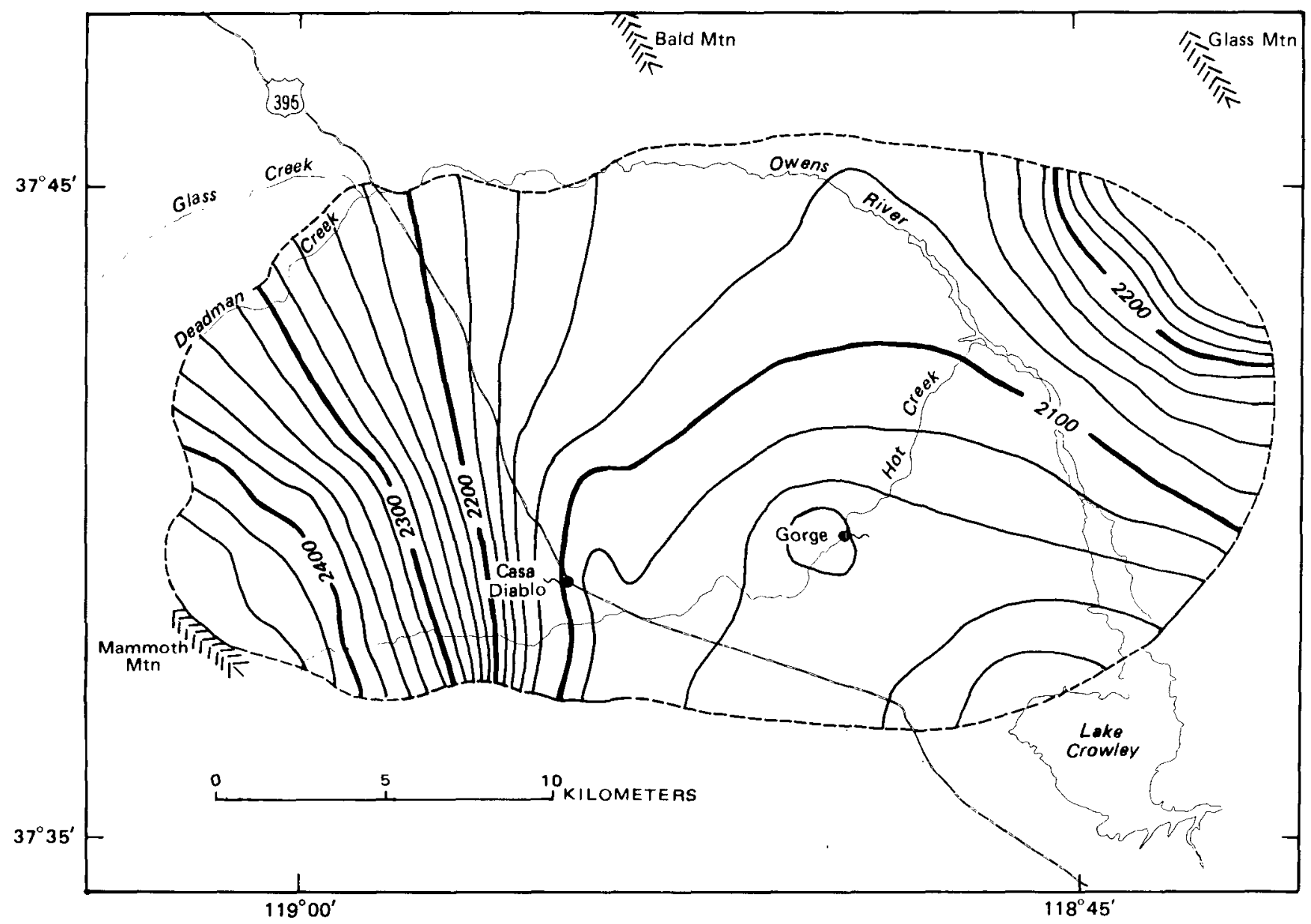

Figure 23.-Sketch map of Long Valley caldera showing equivalent hydraulic head in reservoir from 1 to $2 \mathrm{~km}$ deep from case C with low-permeability-block reservoir west of Casa Diablo Hot Springs, permeability of 45 millidarcys in remainder of western three-fifths of caldera, and permeability of 30 millidarcys in eastern two-fifths of caldera. Discharge in Hot Creek gorge equals $250 \mathrm{~kg} / \mathrm{s}$; southeast rim outflow equals $110 \mathrm{~kg} / \mathrm{s}$. Simulation period equals 35,000 years. Contours of equivalent hydraulic head in meters above mean sea level. Interval $20 \mathrm{~m}$. 
model, in spite of the fact that hydraulic connection between the deep and shallow subsystems was simulated only in the recharge and discharge areas. Equivalent reservoir heads along the west rim are lower than water-table altitudes because of head losses incurred in downflow to the reservoir. Heads along the northeast rim are above water-table altitudes, which implies that artesian conditions are required in the shallow ground-water subsystem below the uppermost unconfined aquifer if recharge to the deep subsystem occurs in that area. Numerous flowing wells and springs on the flanks of Glass Mountain indicate that artesian conditions do exist. As discussed previously, the magnitude of reservoir head needed to obtain an assumed inflow of $110 \mathrm{~kg} / \mathrm{s}$ in the northeast rim is dependent on the value of permeability used. Less head would have resulted if either a higher permeability or less inflow were simulated in this region. However, both quantities are constrained to be close to the chosen values; permeability in the eastern caldera is unlikely to exceed that in the western caldera because of the absence of surficial faulting, and inflow from the northeast rim must be sufficient to produce relatively low temperatures observed in the Bishop Tuff in the deep test hole.

An alternative possibility is that the reservoir in the east part of the caldera is hydraulically separated from the reservoir in the west part, perhaps along the east margin of the intracaldera Hilton Creek fault zone, which could act as a barrier due to sealing effects of hydrothermal alteration. This would have little effect on fluid circulation and temperatures in the model simulations of the western three-fifths of the caldera but might lower the head requirements for recharge from the northeast rim.
In most of the west part of the caldera, equivalent reservoir heads are below water levels in the shallow ground-water subsystem, which indicates a potential for downward flow through the shallow subsystem. Whether such flow actually occurs depends, of course on the vertical permeability distribution. Additional data from drill holes deeper than $300 \mathrm{~m}$ in the western part of the caldera are needed to adequately assess the degree of interconnection between the shallow and deep ground-water subsystems.

\section{THERMAL CHARACTERISTICS}

Any model of the hydrothermal system in Long Valley is constrained by the estimates of natural heat discharge from the caldera and hot-water discharge from the reservoir. Our best estimate of the heat discharge by convection and conduction is $6.9 \times 10^{7} \mathrm{cal} / \mathrm{s}$. The ranges in mass flux and maximum reservoir temperature, obtained from geochemical mixing models, are from 190 to $300 \mathrm{~kg} / \mathrm{s}$ and from $210^{\circ} \mathrm{C}$ to $282^{\circ} \mathrm{C}$, with the highest reservoir temperature corresponding to the lowest mass flux. The magnitude of heat discharge, which requires a heat supply of $15 \mathrm{HFU}$ averaged over the area of the caldera, places severe demands on the underlying heat source, depending upon the length of time it has persisted. In this section we describe the use of the numerical model to evaluate conditions under which an underlying magma chamber could supply the required heat for various periods of time, including the steady-state condition.

The important thermal features of the model are discussed with reference to figure 24, which shows steady-state isotherms in an east-west cross section

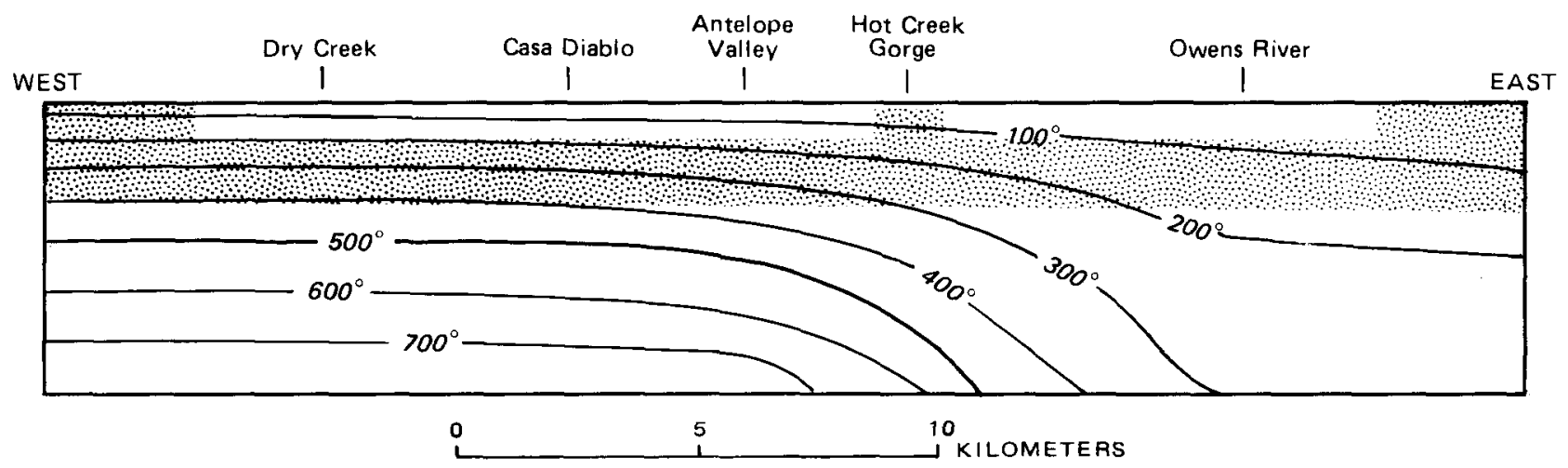

Figure 24.-Diagrammatic east-west cross section of Long Valley caldera showing steady-state, conduction-only isotherms from model simulations without fluid flow and used as initial conditions in simulations of flow in the hydrothermal system. Dotted pattern indicates simulated reservoir and vertical fow channels through confining layers of shallow ground-water subsystem. Thermal properties of each layer in the model are given in table 15. Lines of equal temperature in degrees Celsius. Interval $100^{\circ} \mathrm{C}$ 
passing through Hot Creek gorge. This is the temperature distribution that would exist in the absence of fluid flow, or under conduction-only conditions, with the boundary conditions used in the model. At the bottom, a constant temperature distribution is imposed with $800^{\circ} \mathrm{C}$ under the western half, $300^{\circ} \mathrm{C}$ under the eastern third, and a linear variation between. As discussed, this boundary condition is intended to simulate magma at $6 \mathrm{~km}$ under the western half of the caldera; the $300^{\circ} \mathrm{C}$ temperature under the eastern part was selected to yield conductive heat flows near 2 HFU at the east rim as constrained by the measured heat flows in that area (Lachenbruch, Sass, Munroe, and Moses, 1976). A constant temperature of $10^{\circ} \mathrm{C}$ is imposed at the land surface except in the discharge area at Hot Creek gorge. The caldera walls are treated as insulated boundaries. The reservoir depth shown in figure 24 is from 1 to $2 \mathrm{~km}$; other simulations involved reservoir depths from 2 to $3 \mathrm{~km}$ and from 1 to $3 \mathrm{~km}$.
As discussed previously, the assumption that magma has existed at depths from 6 to $8 \mathrm{~km}$ during the last 0.3 $\mathrm{m}$.y. is reasonable. Our transient analysis of the hydrothermal system also involves a period of approximately 0.3 m.y., which is sufficient for steady-state conditions to be reached. We are primarily interested in thermal conditions after two distinct periods of flow, one being the 30,000-40,000-year period of recent spring flow which has contributed salts to Searles Lake (Smith, 1976); the other being the 0.3-m.y. period since the earliest indicated time of extensive hydrothermal activity (Bailey and others, 1976). The initial temperature distribution used in our transient simulation is the steady-state, conduction-only, condition shown in figure 24. For the recent period of spring flow, the use of this initial condition would be valid if the system has had nearly 0.3 m.y. to equilibrate conductively after cessation of the earlier period of hydrothermal activity. This would correspond to the concept of intermittent

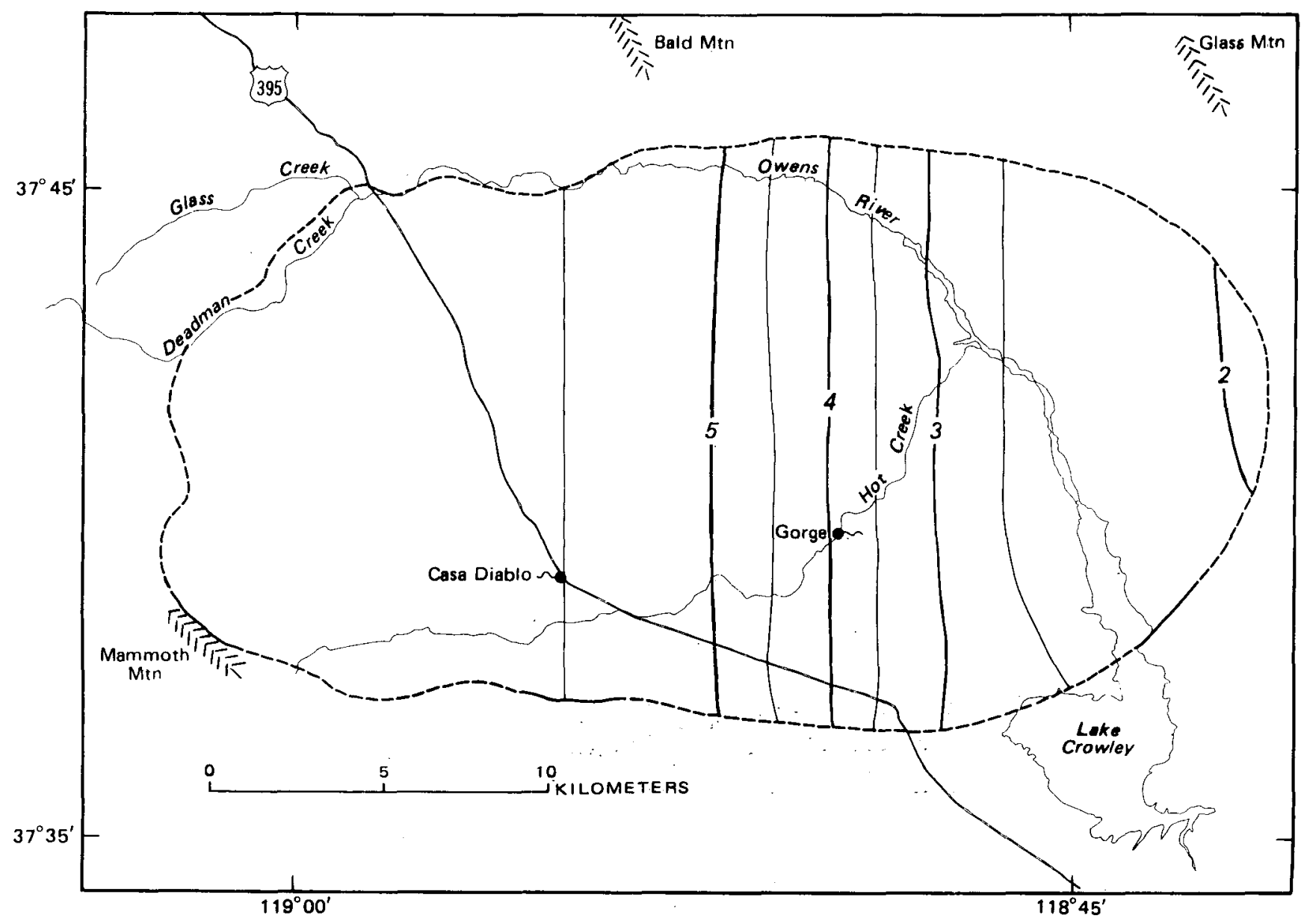

FiguRE 25.-Map of Long Valley caldera showing steady-state conductive heat flow above reservoir (from model simulation) without fluid flow. Lines of equal heat flow in heat-flow units (HFU). Interval $0.5 \mathrm{HFU}$. 
hydrothermal activity discussed previously. In contrast, if spring flow has been continuous over the past 0.3 m.y., our 0.3.-m.y.-period simulation would indicate the present-day steady-state thermal condition, even though the assumed initial condition in figure 24 did not exist 0.3 m.y. ago.

In figure 25 the areal distribution of heat flow under the initial temperature conditions is shown. The total conductive heat flow is $2.1 \times 10^{7} \mathrm{cal} / \mathrm{s}$, and the heat flux varies from 5.7 HFU near the west rim to $2.0 \mathrm{HFU}$ near the east rim. Comparison with the measured total heat flow of $6.9 \times 10^{7} \mathrm{cal} / \mathrm{s}$ and the measured surficial heat-flow map (fig. 15) indicates the extent to which ground-water circulation affects the thermal regime of the caldera.

Simulation of ground-water flow through the hydrothermal system produces the temperature distributions illustrated in figures 26 and 27 . These results are for a continuous reservoir (case A) at a depth of 1 to $2 \mathrm{~km}$, with a hot-spring discharge of $250 \mathrm{~kg} / \mathrm{s}$ persisting for 35,000 years. Temperatures in the east-west cross section in figure 26 indicate the cooling effect of recharge near the west rim, the increased temperature gradients and heat flows below the reservoir in the west part of the caldera, and the gradual heating of the reservoir fluid as it moves eastward toward the discharge area at Hot Creek gorge. The temperature in the middle of the reservoir beneath the gorge is near $200^{\circ} \mathrm{C}$, and lateral heat conduction away from the rising column of hot water causes the high temperatures in the adjacent shallow subsystem. The effect of recharge from the northeast rim is also evident with reservoir temperatures of about $80^{\circ} \mathrm{C}$ in the southeast part of the caldera. These lower temperatures are reasonably consistent with results from the deep test hole.
The areal distribution of reservoir temperature shown in figure 27 applies to the midplane of the reservoir at $1.5-\mathrm{km}$ depth, and could be considered as average reservoir temperatures. This interpretation is, of course, limited by the coarseness of the vertical nodal spacing used in the model. One observation from the results shown in figure 27 is that a laterally extensive layer of uniform temperature does not exist, although reservoir temperatures below the area of present-day hot-spring discharge around the southeast flank of resurgent dome are between about $180^{\circ} \mathrm{C}$ and $240^{\circ} \mathrm{C}$. Reservoir temperatures below the Casa Diablo area, however, are only about $120^{\circ} \mathrm{C}$, whereas measured and chemically estimated temperatures at depth exceed $180^{\circ} \mathrm{C}$. The lower temperatures from the model simulation result from the proximity of Casa Diablo to the recharge area around the west rim.

The low-permeability-block permeability distribution, case $\mathrm{C}$ discussed previously, offers an alternative model which produces higher temperatures under Casa Diablo. The temperature distributions at 35,000 years in cross section and plan for this case are shown in figures 28 and 29. A pronounced temperature and heat-flow anomaly west of Casa Diablo is produced by the permeability barrier which diverts the eastwardly ground-water flow to the north. In this case, average reservoir temperatures are near $180^{\circ} \mathrm{C}$ under Casa Diablo as well as under Hot Creek gorge. Existing testhole data west of Casa Diablo are too sparse and too shallow to confirm the presence of the temperatureheat-flow anomaly shown in figure 28 . Additional test drilling might delineate this as a potential area for hot-dry-rock exploration.

Results for the fault-zone-reservoir (case B, fig. 20), for a similar period of flow in a more areally restricted

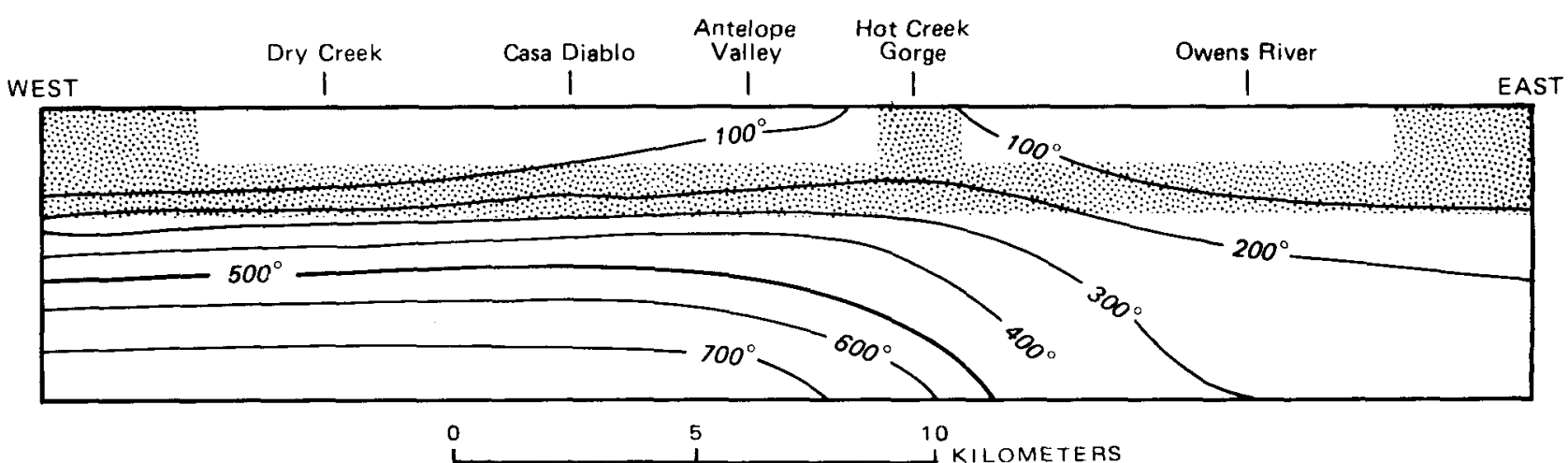

Figure 26.-Diagrammatic east-west cross section of Long Valley caldera showing isotherms from model simulation (case A-uniform reservoir permeability distribution) after 35,000 years with a discharge of $250 \mathrm{~kg} / \mathrm{s}$ in Hot Creek gorge, southeastrim outflow of $110 \mathrm{~kg} / \mathrm{s}$, and reservoir depth of 1 to $2 \mathrm{~km}$. Lines of equal temperature in degrees Celsius. Interval $100^{\circ} \mathrm{C}$. 


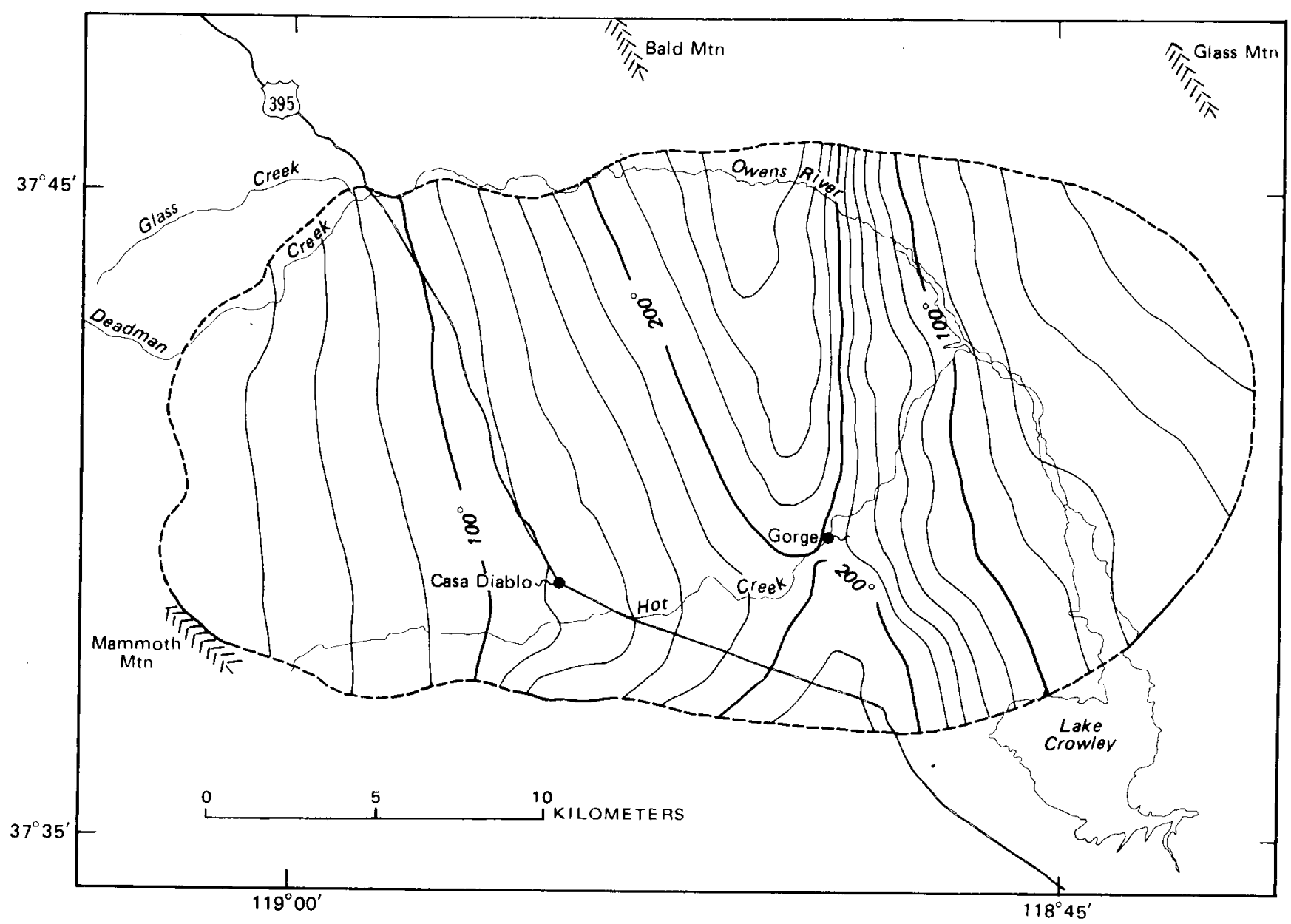

FIGURE 27.-Map of Long Valley caldera showing distribution of average reservoir temperature from model simulation (case A--uniform reservoir permeability distribution) after 35,000 years with a discharge of $250 \mathrm{~kg} / \mathrm{s} \mathrm{in} \mathrm{Hot} \mathrm{Creek} \mathrm{gorge,} \mathrm{southeast-rim} \mathrm{outflow} \mathrm{of} 110 \mathrm{~kg} / \mathrm{s}$, and reservoir depth of 1 to $2 \mathrm{~km}$. Lines of equal temperature in degrees Celsius. Interval $20^{\circ} \mathrm{C}$

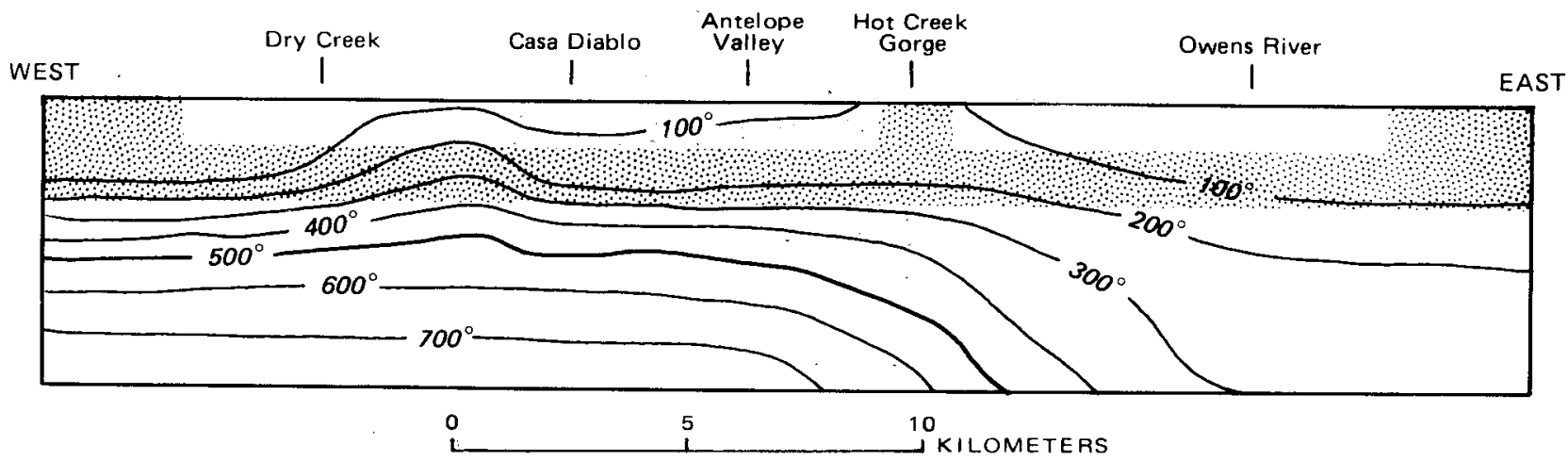

FIGURE 28.-Diagrammatic east-west cross section of Long Valley caldera showing isotherms from model simulation (case C-- low permeability-block reservoir west of Casa Diablo) after 35,000 years with discharge of $250 \mathrm{~kg} / \mathrm{s}$ in Hot Creek gorge, southeastrim outflow of $110 \mathrm{~kg} / \mathrm{s}$, and reservoir depth of 1 to $2 \mathrm{~km}$. Lines of equal temperature in degrees Celsius. Interval $100^{\circ} \mathrm{C}$. 
reservoir at a 1-2-km depth, yield maximum reservoir temperatures of only about $100^{\circ} \mathrm{C}$. These lower temperatures are caused by the reduced area for heat flow into the reservoir. To obtain higher reservoir temperatures with this model, deeper circulation is required.

As discussed in the section "Chemical Geothermometers," estimates of actual maximum reservoir temperatures and fluxes of hot water vary. The analysis by Sorey and Lewis (1976) indicates a reservoir with $210^{\circ} \mathrm{C}$ water discharging from 250 to $300 \mathrm{~kg} / \mathrm{s}$; the analysis by Fournier, Sorey, Mariner, and Truesdell (1976) indicates a $282^{\circ} \mathrm{C}$ reservoir discharging from 190 to $230 \mathrm{~kg} / \mathrm{s}$. However, convective heat flows for each case, based on equation (1), are not significantly different. This is in agreement with the model results which show that, for a given reservoir depth and period of spring flow, maximum reservoir temperatures are inversely related to the mass-flux rate. For example, if in the continuous-reservoir case shown in figures 26 and 27 , a mass flux of $190 \mathrm{~kg} / \mathrm{s}$ instead of $250 \mathrm{~kg} / \mathrm{s}$ is simulated, reservoir temperatures under Hot Creek gorge near $245^{\circ} \mathrm{C}$ instead of $200^{\circ} \mathrm{C}$ are obtained. Thus the choice of which geochemical model of reservoir temperature and flux to match with these simulations is perhaps not as important at this stage as is the matching of total heat flow from the model with the measured value of $6.9 \times 10^{7} \mathrm{cal} / \mathrm{s}$.

Heat flows corresponding to the three cases of reservoir permeability distribution discussed above, are listed in table 16.

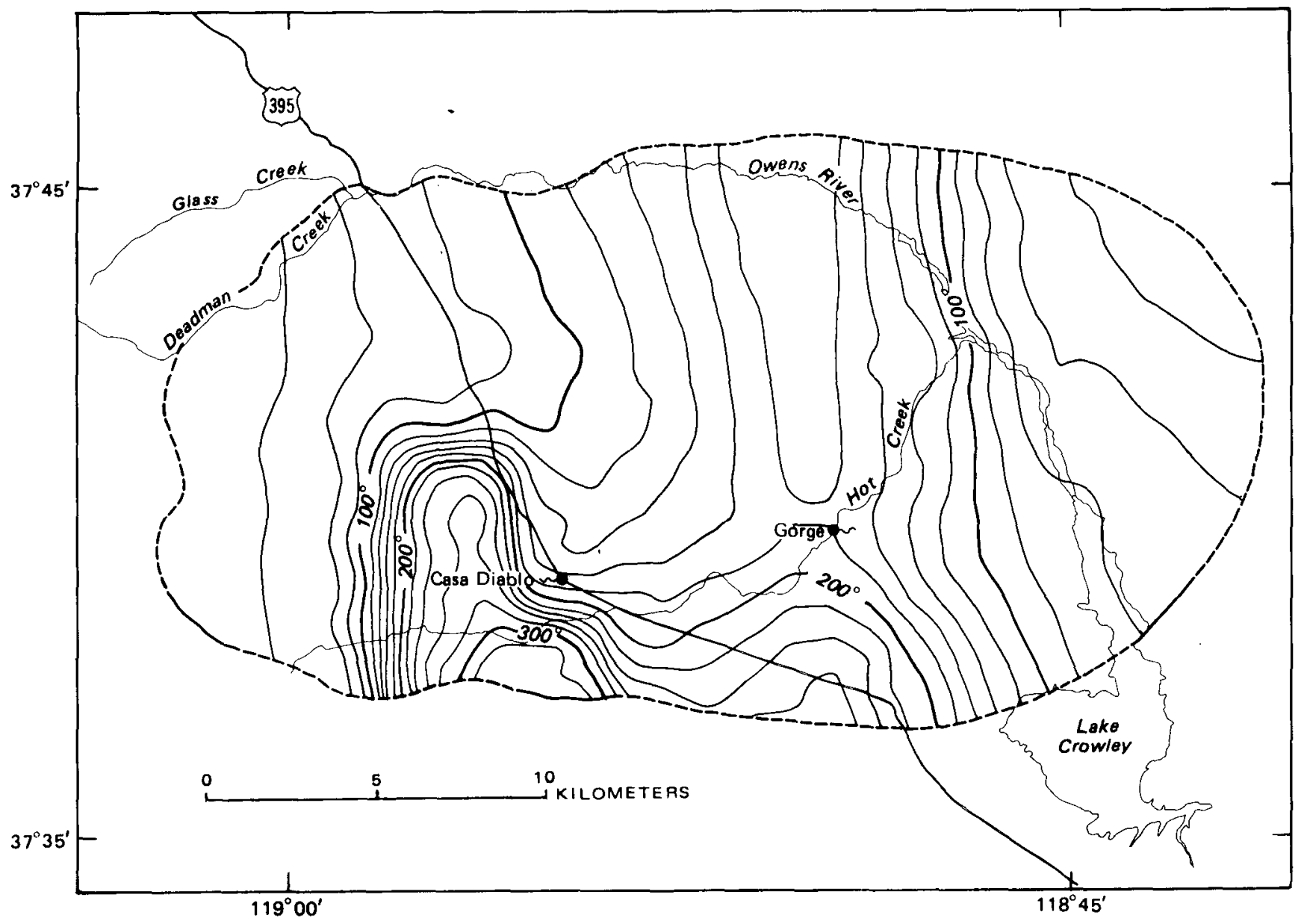

Figure 29.-Map of Long Valley caldera showing distribution of average reservoir temperature from model simulation (case Clow-permeability-block reservoir west of Casa Diablo) after 35,000 years with discharge of $250 \mathrm{~kg} / \mathrm{s}$ in Hot Creek gorge, southeast-rim outflow of $110 \mathrm{~kg} / \mathrm{s}$, and reservoir depth of 1 to $2 \mathrm{~km}$. Lines of equal temperature in degrees Celsius. Interval $20^{\circ} \mathrm{C}$. 
TABLE 16.-Conductive and convective heat discharge for each case of reservoir-permeability distribution after 35,000 years of fluid flow at $250 \mathrm{~kg} / \mathrm{s}$ in reservoir at $1-2-\mathrm{km}$ depth

\begin{tabular}{cccc}
$\begin{array}{c}\text { Reservoir- } \\
\text { permeability } \\
\text { case }\end{array}$ & $\begin{array}{c}\text { Conductive } \\
\text { heat discharge } \\
\text { (cal/s) }\end{array}$ & $\begin{array}{c}\text { Convective } \\
\text { heat discharge } \\
\text { (cal/s) }\end{array}$ & $\begin{array}{c}\text { Total } \\
\text { (cal/s) }\end{array}$ \\
\hline A & $1.6 \times 10^{7}$ & $4.9 \times 10^{7}$ & ${ }^{16.5 \times 10^{7}}$ \\
B & $1.4 \times 10^{7}$ & $2.2 \times 10^{7}$ & $3.6 \times 10^{7}$ \\
C & $1.8 \times 10^{7}$ & $4.2 \times 10^{7}$ & $16.0 \times 10^{7}$ \\
\hline
\end{tabular}

${ }^{1}$ Does not include $1.4 \times 10^{7} \mathrm{cal} / \mathrm{s}$ advected through southeast caldera rim.

These results indicate that present-day heat flow could be obtained after a period of 35,000 years with an average depth of hydrothermal circulation of $1.5 \mathrm{~km}$, provided the reservoir is continuous over the western half of the caldera. For a more areally restricted reservoir, correspondingly deeper circulation is required.

Conductive heat flows in table 16 were determined from the temperature distributions in layer 1 at a depth of $0.5 \mathrm{~km}$. The areal distribution of surficial heat flow for the continuous-reservoir case is shown in figure 30. Differences between this map and the measured shallow-heat-flow map (fig. 15) are due in part to the effects of shallow ground-water circulation which were neglected in the numerical model. The most obvious effects are seen in the west moat where apparently shallow recharge cools ground temperatures over a sizable area, and east of Hot Creek gorge where lateral flow of warm water in the shallow system causes a high-heat-flow bulge to the southeast.

FIGURE 30.-Map of Long Valley caldera showing results from model simulations (case A-uniform reservoir-permeability distribution) in terms of conductive heat flow above a depth of $0.5 \mathrm{~km}$ after 35,000 years with discharge of $250 \mathrm{~kg} / \mathrm{s}$ in Hot Creek gorge, southeast-rim outflow of $110 \mathrm{~kg} / \mathrm{s}$, and reservoir depth of 1 to $2 \mathrm{~km}$. Lines of equal heat flow in heat-flow units. Interval $1.0 \mathrm{HFU}$. 
If hot-spring discharge continues for periods greater than 35,000 years, reservoir temperatures cool significantly from the previous results. For the dimensions and parameters used in these simulations, temperatures would be close to steady state after 350,000 years. The temperature distribution in cross section corresponding to the continuous-reservoir (from 1 to 2 $\mathrm{km}$ deep) case after 350,000 years of spring flow is shown in figure 31 . Additional heat has been removed from the rocks above and below the reservoir, and reservoir temperatures below the gorge have dropped from about $200^{\circ} \mathrm{C}$ to about $100^{\circ} \mathrm{C}$. The total heat flow is now only $2.7 \times 10^{7} \mathrm{cal} / \mathrm{s}$, which does not include $0.7 \times$ $10^{7} \mathrm{cal} / \mathrm{s}$ advected through the southeast rim of the caldera.

The transient response of reservoir temperature under the gorge is plotted in figure 32 for case A and two reservoir depths. In each simulation the early-time increase in reservoir temperature under the discharge area, prior to about 10,000 years, is due to the arrival of hotter water from the west (see fig., 24). After about 10,000 years, discharge temperatures decrease continuously until steady state is reached after approximately 350,000 years.

It is possible to calculate the average travel time of water in the reservoir from the time at which the cold temperature wave arrives under the gorge. The effective Darcy, or seepage, velocity ve, can be computed from equation (3) (neglecting heat conduction) as

$$
v_{e}=(L / t)\left[(\rho c)^{\prime} / \rho c\right]
$$

with $L=$ the average distance from recharge to discharge area and $t=$ time for arrival of the cold temperature wave. For $L=20 \mathrm{~km}, t=10,000$ years, $(\rho c)^{\prime}=0.6$ $\mathrm{cal} /\left({ }^{\circ} \mathrm{C} \mathrm{cm}^{3}\right)$, and $\rho c=1 \mathrm{cal} /\left({ }^{\circ} \mathrm{C} \mathrm{cm}^{3}\right)$, ve $=0.003 \mathrm{~m} / \mathrm{d}$. The average pore velocity, $v^{*}=v e /$ porosity, would then be $0.003 / 0.1=0.03 \mathrm{~m} / \mathrm{d}$, indicating that most of the recharge water would show up in the hot springs after about 2,000 years. These calculations apply to a reservoir $1 \mathrm{~km}$ thick. If the Long Valley hydrothermal reservoir is less than $1 \mathrm{~km}$ thick, pore velocities would be proportionately greater and travel times proportionately smaller.

The transient responses shown in figure 32 are not expected to represent the caldera's actual thermal history over the entire period shown. Instead, results for the first 35,000-year period apply to the recent period of boron accumulation in Searles Lake, and would be valid only if the hydrothermal system, after initial activity, was then inactive for close to the 300,000 years needed for conductive equilibrium to be reestablished. In contrast, results for steady-state conditions (at 350,000 years in fig. 32 ) would apply to the present day only if hydrothermal activity has been reasonably continuous for the past 350,000 years at close to present rates.

Reservoir temperatures under Hot Creek gorge at 35,000 and 350,000 years from all of the numerical simulations are listed in table 18. The effects of both mass-flux rate and reservoir depth on reservoir temperatures can be seen. These results indicate that if present-day hydrothermal activity has persisted for only about 35,000 years, estimated reservoir temperatures and heat flow could be supplied by a magma chamber at $6 \mathrm{~km}$ with fluid circulation to from 1.5 to $2.5 \mathrm{~km}$ over the western three-fifths of the caldera. More areally restricted circulation (case B) or greater depths to magma would require correspondingly deeper circulation.

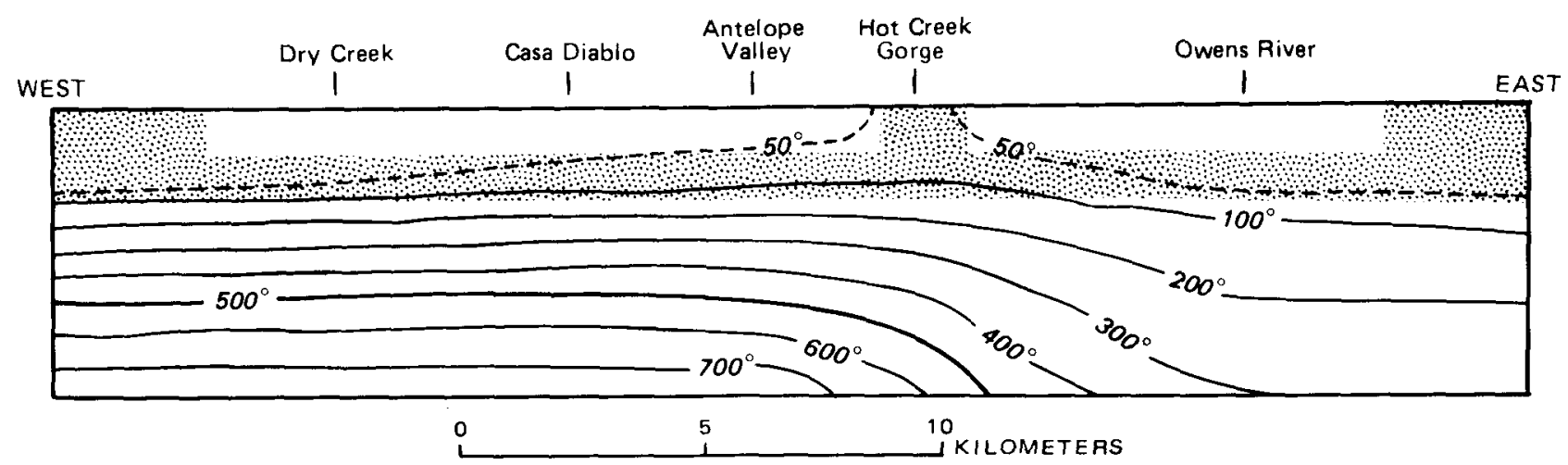

Figure 31.-Diagrammatic east-west cross section of Long Valley caldera showing isotherms from model simulation (case A-uniform reservoir-permeability distribution) after 350,000 years with hot-spring discharge of $250 \mathrm{~kg} / \mathrm{s}$, southeast-rim outflow of $110 \mathrm{~kg} / \mathrm{s}$, and reservoir depth of 1 to $2 \mathrm{~km}$. Lines of equal temperature in degrees Celsius. Interval $100^{\circ} \mathrm{C}$. 
TABLE 17.-Average reservoir temperature below Hot Creek gorge for various model runs

\begin{tabular}{|c|c|c|c|c|}
\hline Run specifications ${ }^{12}$ & $\begin{array}{c}\text { Reservoir } \\
\text { depth } \\
(\mathrm{km})\end{array}$ & $\begin{array}{c}\text { Initial } \\
T \\
\left({ }^{\circ} \mathrm{C}\right)\end{array}$ & $\begin{array}{c}\mathrm{T} \text { after } \\
35,000 \mathrm{yrs} \\
\left({ }^{\circ} \mathrm{C}\right)\end{array}$ & $\begin{array}{c}\mathrm{T} \text { after } \\
350,000 \mathrm{yrs} \\
\left.{ }^{\circ} \mathrm{C}\right)\end{array}$ \\
\hline $\begin{array}{l}\text { 1. Case A, } M=300 \\
\text { 2. Case A, M }=250 \\
\text { 3. Case A, } M=190 \\
\text { 4. Case B, } M=250 \\
\text { 5. Case C, } M=250 \\
\text { 6. Case A, } M=300 \\
\text { 7. Case C, } M=250 \\
\text { 8. Case A, } M=250\end{array}$ & $\begin{array}{l}1-2 \\
1-2 \\
1-2 \\
1-2 \\
1-2 \\
2-3 \\
2-3 \\
1-3\end{array}$ & $\begin{array}{l}260 \\
260 \\
260 \\
260 \\
260 \\
345 \\
345 \\
300\end{array}$ & $\begin{array}{l}179 \\
203 \\
245 \\
100 \\
185 \\
262 \\
270 \\
255\end{array}$ & $\begin{array}{r}95 \\
102 \\
120 \\
60 \\
101 \\
124 \\
135 \\
142\end{array}$ \\
\hline
\end{tabular}

${ }^{1}$ Applies to reservoir-permeability distributions in figs. $19-21$.

${ }^{2} \mathrm{M}=$ mass discharge in Hot Creek gorge springs in $\mathrm{kg} / \mathrm{s}$; additional cooler discharge of $110 \mathrm{~kg} / \mathrm{s}$ simulated through southeast rim in each run except that for case $\mathrm{B}$.

The model results in table 17 can also be used to infer that under steady-state conditions, present-day reservoir temperature and heat flow could be supplied by conduction from a magma chamber at $6 \mathrm{~km}$ only if fluid circulation in the model extended to depths of 4 to 5 $\mathrm{km}$. Alternatively, the effective depth to magma, or the thickness of a conducting, impermeable roof, must be only 1 to $2 \mathrm{~km}$ thick. Unfortunately, it is not as yet known whether fluid circulation to such depths does, in fact, occur. From structural considerations, calculations of depths at which the compressive strengths of rocks are exceeded suggest that from 4 to $5 \mathrm{~km}$ may be a maximum (King, 1971). However, recent stableisotope data showing effects of interactions of volcanic rocks with circulating meteoric ground water indicate that fluid circulation to from 5 to $10 \mathrm{~km}$ is possible (J. R. O'Neil, oral commun., 1977, and Taylor, 1976, p. 41). Thermal modeling results show that without deep circulation, hydrothermal discharge near or in excess of present rates could not have been sustained continuously over the last $0.3 \mathrm{~m} . y$. by conduction from an underlying magma chamber. In this event, an intermittent character for the hydrothermal system is implied.

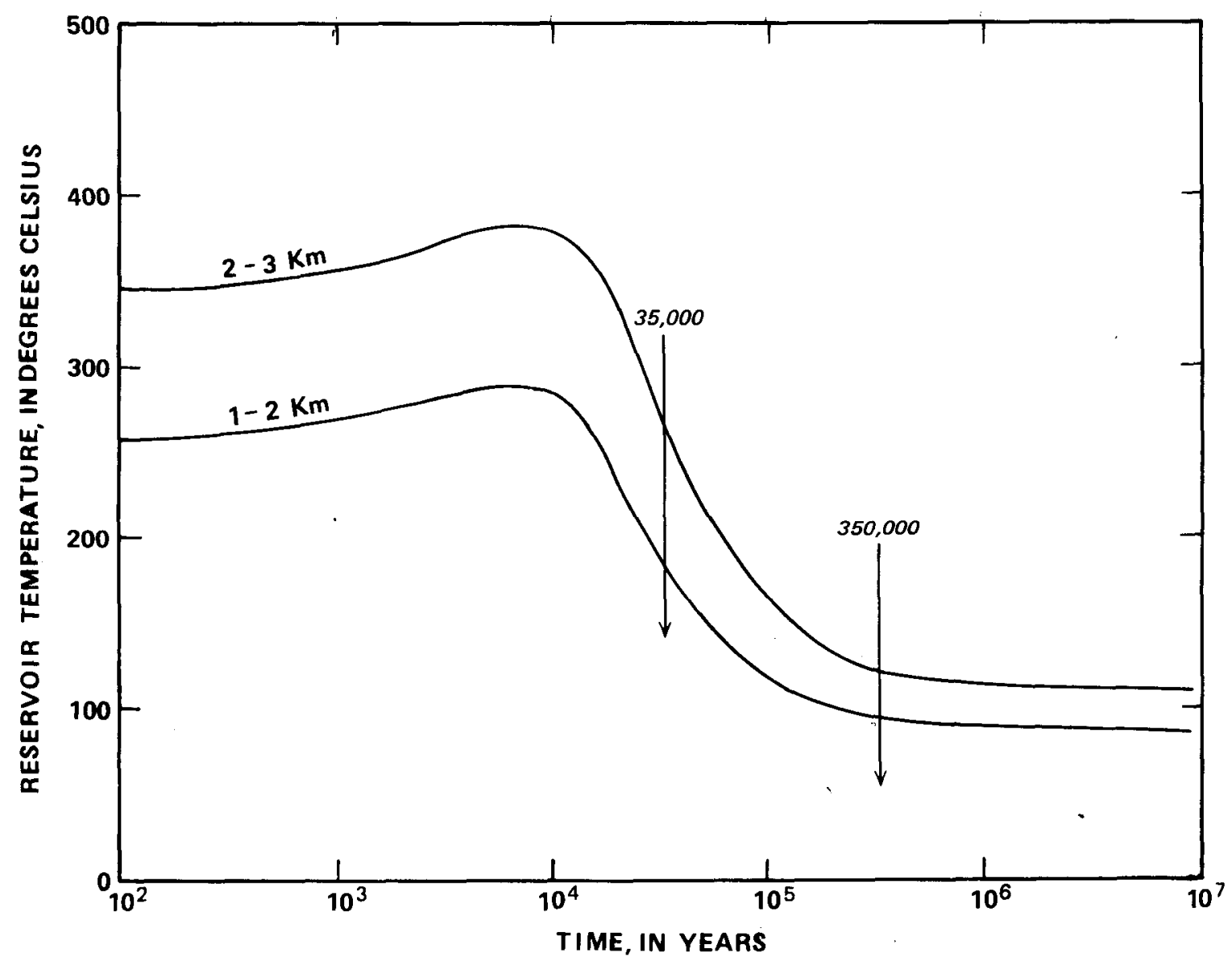

FiguRE 32.-Transient response since initiation of springfiow of average reservoir temperature below Hot Creek gorge for two reservoir depths, from model simulation (case A-uniform reservoir-permeability distribution) with discharge of $300 \mathrm{~kg} / \mathrm{s}$ in Hot Creek gorge and southeast-rim outflow of $110 \mathrm{~kg} / \mathrm{s}$. 
The thermal modeling results and the chemical discharge records are consistent with the concept of an initial period of hydrothermal activity around $0.3 \mathrm{~m} . \mathrm{y}$. ago, followed by nearly $0.25 \mathrm{~m}$.y. of inactivity until the present system was established-approximately 35,000 years ago. Under these conditions, hydrothermal circulation through the fractured Bishop Tuff at depths of 1 to $3 \mathrm{~km}$ in the western three-fifths of the caldera is plausible.

The possibility that cellular convection within the reservoir might increase the rate of vertical heat transfer, yielding higher discharge temperatures, and also causing a more uniform reservoir temperature distribution, was also examined. Simulations with uniform permeability in a reservoir $2 \mathrm{~km}$ thick, which included nodal layers 2 and 3 , enabled vertical flow components to be determined. The likelihood of cellular convection is related to the dimensionless Rayleigh number $(\mathrm{Ra})$, which for variable fluid properties can be calculated from Sorey (1975) as

$$
\mathrm{Ra}_{m}=\frac{g k L(\Delta T)}{K_{m}}\left[\frac{\rho_{o}{ }^{2} c_{m} \beta_{e}}{\mu_{m}}\right]
$$

where the subscript $m$ indicates evaluation at the average temperature in the layer in the absence of convection, and $\Delta T$ is the temperature difference across the layer of thickness $L$. The effective thermal expansivity, $\beta_{e}$, is computed as

$$
\beta_{e}=\left(\rho_{0}-\rho_{1}\right) /\left(\rho_{0} \Delta T\right)
$$

where $\rho_{0}$ and $\rho_{1}$ are evaluated at top and bottom, respectively, of the permeable layer. For the conductiononly temperature distribution in figure $24, \mathrm{Ra}_{m}=1,500$ in the west part of the caldera and 500 in the east part. For a horizontal layer of large lateral extent and taking into account temperature-dependent fluid properties, cellular convection should occur for $\mathrm{Ra}_{m}>70$ (Sorey, 1975, p. 33). Thus, if the Long Valley reservoir
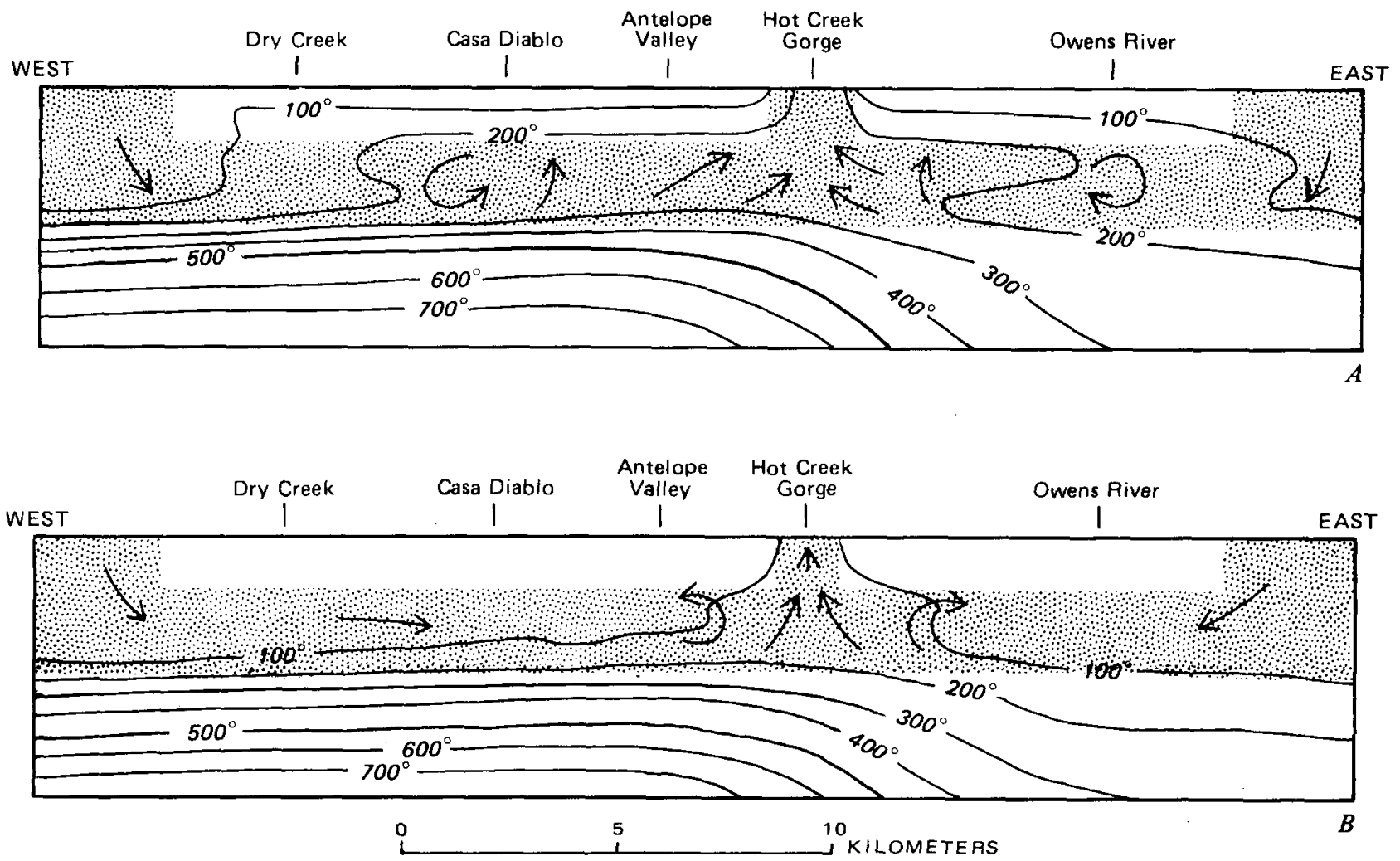

FIGURE 33.-Diagrammatic east-west cross sections of Long Valley caldera showing isotherms and convection patterns from model simulations (case $A$ - uniform reservoir-permeability distribution) after 35,000 years $(A)$ and 350,000 years $(B)$, with cellular convection in reservoir at 1-3-km depth, hot-spring discharge of $250 \mathrm{~kg} / \mathrm{s}$, and southeast-rim outflow of $110 \mathrm{~kg} / \mathrm{s}$. Lines of equal temperature in degrees Celsius. Interval $100^{\circ} \mathrm{C}$. Arrows show inferred direction of fluid flow related to throughflow and cellular convection in reservoir. 
is uniformly permeable and as thick as $2 \mathrm{~km}$, a vigorous cellular convection motion would be expected.

The results in table 17 for the reservoir from 1 to 3 $\mathrm{km}$ deep (run 8), in which convection cells did occur, also include the effects of a $250-\mathrm{kg} / \mathrm{s}$ discharge in the hot springs and $110 \mathrm{~kg} / \mathrm{s}$ discharge through the southeast rim. Comparisons with single-layer reservoir runs with the same throughflows indicate average reservoir temperatures under the gorge which are close to the $2-3-\mathrm{km}$ reservoir results at 35,000 years and 350,000 years. Total heat discharge for run 8 was $10.6 \times 10^{7}$ $\mathrm{cal} / \mathrm{s}$ at 35,000 years and $4.9 \times 10^{7} \mathrm{cal} / \mathrm{s}$ at 350,000 years.

Isotherms and convective patterns in east-west cross sections for run 8 are shown in figure 33. At 35,000 years a two-convection-cell pattern with axes alined northwest was observed, superimposed on the eastward- and southward-throughflow regimes. The isotherms form a mushroom configuration similar to that observed in the Wairakei hydrothermal system (Elder, 1965). Comparison with figure 26 for the single-layer reservoir indicates that the convection cells produce more areally uniform reservoir temperature conditions, extending westward from Hot Creek gorge to the Casa Diablo area. At longer times, the cooler throughflow tends to sweep out the cellular mo- tion west and east of the gorge, although some effect is still evident under the gorge.

This analysis is limited primarily by the coarseness of the nodal spacing in the vertical direction. It would be anticipated that, if more layers of nodes were added to the simulated reservoir without changing its total thickness, higher rates of heat transfer and higher discharge temperatures would have been obtained. At 35,000 years this effect could make circulation in a reservoir from 1 to $2 \mathrm{~km}$ deep appear more plausible from a heat-flow standpoint. At longer times, however, the observed tendency for throughflow to sweep out the vertical convective motions indicates that cellular convection would be a dominant influence on the thermal regime only if throughflow in the hydrothermal system were more restricted than at present.

The effect of the coarseness of the vertical nodal spacing also causes a lowering in vertical heat-transfer rates in the single-layer-reservoir simulations. This effect would be more important at earlier times when the vertical temperature distribution is strongly nonlinear, and when conductive heat fluxes from adjacent layers into the reservoir-and hence, reservoir temperatures-are underestimated. Because of the expense involved in using finer vertical node spacing in the 3-dimensional simulations, the magnitude of this

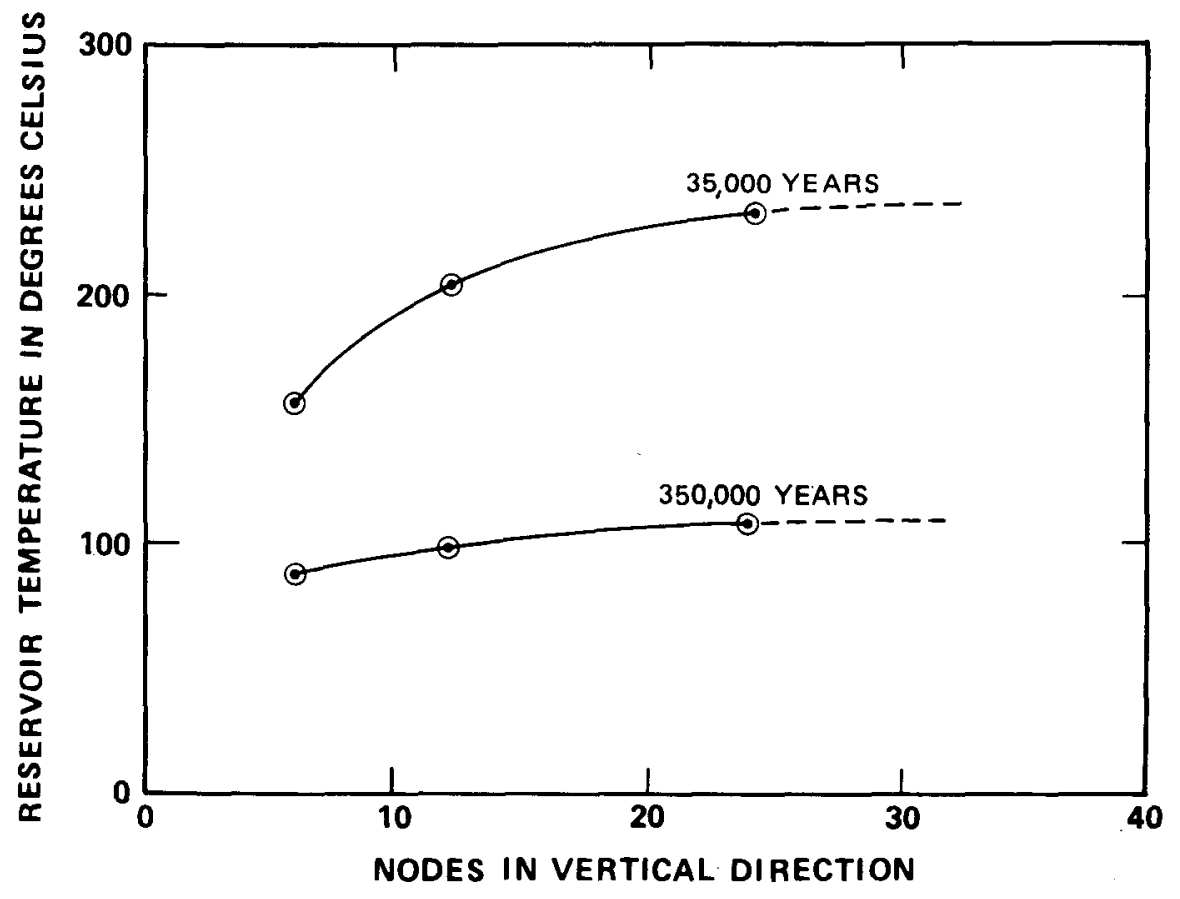

FIGURE 34.-Effect of nodal spacing in vertical direction on average reservoir temperature under Hot Creek gorge after 35,000 years and 350,000 years of fluid flow in 2-dimensional, vertical-cross-section model simulation of Long Valley hydrothermal system. Cross section aligned east-west from Hot Creek gorge to west rim; mass flux through reservoir between $1-2-\mathrm{km}$ depth set at $1 / 10$ th of flux in 3-dimensional model, or $25 \mathrm{~kg} / \mathrm{s}$. 
effect was examined for a roughly equivalent, 2-dimensional vertical-cross-section problem. Results, as indicated in figure 34 , indicate that the grid spacing in the 3-dimensional model, with 5 nodal layers in the vertical direction, could cause average reservoir temperatures to be underestimated by as much as 35 percent at 35,000 years and 20 percent at 350,000 years. Obviously, this is a significant effect, which bears directly on the estimates of reservoir depths required for short-term $(35,000$ years $)$ and steady-state $(350,000$ years) hydrothermal activity. However, it may be largely offset by the likelihood that the Long Valley magma chamber is actually deeper and less extensive than assumed in this model.

Reservoir temperatures obtained from the 3-dimensional model runs beneath the southeastern part of the caldera, near the location of the deep test well (pl. 1, well 66-29), range from $80-90^{\circ} \mathrm{C}$ at 35,000 years to around $50^{\circ} \mathrm{C}$ at steady state for the 12 -km-deep-reservoir case. Temperatures measured in the test hole were between $50^{\circ} \mathrm{C}$ and $70^{\circ} \mathrm{C}$ from below about $200 \mathrm{~m}$ to the bottom. Thus the concept of recharge from the northeast rim and discharge through the southeast rim at rates near $110 \mathrm{~kg} / \mathrm{s}$ produces thermal conditions consistent with those observed. Other sources for the flux of relatively cool water under the southeastern area cannot be ruled out, such as recharge moving down the Hilton Creek fault from the Sierra Nevada southeast of the caldera. Whatever the source, the pattern of ground-water circulation found in the model simulations with discharge through the southeast rim indicates that little of this water discharges in the hot springs. However, if no such outlet through the southeast rim exists, this flux of cool water would have to move westward under the intracaldera extensions of the Hilton Creek fault to mix with hot water moving from the west and discharge in the Hot Creek gorge springs. On the basis of geochemical and thermal considerations, we prefer the model analyzed in this study, but more data are needed to resolve this question.

It is also possible that within the caldera the easternmost extensions of the Hilton Creek fault (pl. 1 and fig. 19) act as a barrier to the westward movement of cool water at depth. The hydraulic characteristics of the reservoir between the regions of hot-water circulation under the resurgent dome and cool-water circulation east of Hot Creek could be important if future geothermal development involved production of hot fluids from under the dome. If no permeability barrier exists, then movement of the cool water from the east into the production zone may significantly limit the rate or duration of high-enthalpy-fluid production.

\section{CONCLUSIONS AND IMPLICATIONS}

Results of previous investigations by the U.S. Geological Survey and limited information from a recently drilled $2.11-\mathrm{km}$-deep test hole in Long Valley caldera enable a useful conceptual model of the hydrothermal system to be developed. Because of the lack of sufficient data from deep drill holes and because of generalizations required for numerical analysis of heat and fluid flow, the model is oversimplified at this stage. However, the results obtained from numerical simulations with this model permit a useful determination of the general relation between heat flow and the depth and duration of fluid flow, as well as the effective hydraulic characteristics of the hydrothermal reservoir.

The conceptual model is based largely on the following information from previous studies. Seismicrefraction experiments and geological investigations delineate three major rock units: (1) a near-surface layer of low velocity, largely nonindurated sediments and volcanic rocks, (2) an underlying, continuous layer of densely welded Bishop Tuff, and (3) precaldera granitic and metamorphic basement rocks below depths of 2.5 to $3.0 \mathrm{~km}$. Regional heat-fiow, seismicrefraction, and teleseismic analyses, and the recent occurrence of extrusive volcanism suggest that magma or partially molten rock exists under the western threefifths of the caldera at depths of 6 to $8 \mathrm{~km}$. The present-day hydrothermal system is dominated by hot water with aquifer temperatures at depth, estimated from the geochemistry of hot-spring waters, of about $210^{\circ} \mathrm{C}$ to $280^{\circ} \mathrm{C}$.

If a reservoir with significant areal extent exists, it is most likely to occur in the densely welded Bishop Tuff because of the continuity and depth of the tuff and the likelihood that it retains secondary permeability after fracturing. Hydrologic and geochemical studies, including determinations of isotopic contents in caldera waters, indicate that recharge to the hydrothermal system occurs around the western rim, supplying a mass flux of 200 to $300 \mathrm{~kg} / \mathrm{s}$ which discharges in the hot springs and into Lake Crowley in the southeast part of the caldera. Relatively cool temperatures measured in the recently drilled, deep test hole indicate that an additional flux of water may recharge around the northeast rim and flow southward at depth under the eastern third of the caldera.

Numerical simulations of heat and fluid flow in the model yielded values of effective reservoir permeability for several alternative cases of reservoir size. For two cases with nearly homogeneous permeability, in a 1 -km-thick reservoir, permeabilities of 30 to $50 \mathrm{mil}-$ lidarcys were required to produce a hot-spring dis- 
charge of $250 \mathrm{~kg} / \mathrm{s}$. A more areally restricted reservoir case required a permeability of 300 millidarcys. Comparison of these results with laboratory results on cores from Long Valley and the Nevada Test Site and with data from hydraulic tests in wells in fractured tuff at NTS indicate that equivalent-porous-media permeabilities determined in the model simulations represent integrations of the effects of fracture permeability over the volume of the reservoir rock.

Estimates of the average residence time of fluid in a 1-km-thick reservoir, based on a 10,000-year arrival time for the cool temperature wave from recharge around the west rim, are close to 2,000 years. For the same mass flux in a thinner reservoir, the estimated residence time would be proprotionately shorter.

Thermal contraints on the model results are provided by our estimate of the present-day total heat discharge from the caldera of $6.9 \times 10^{7} \mathrm{cal} / \mathrm{s}$, and average reservoir temperatures below discharge areas of $210^{\circ} \mathrm{C}$ to $280^{\circ} \mathrm{C}$. Numerical simulations show that these conditions could have been sustained for a period of 35,000 years by magma at $6 \mathrm{~km}$ under the western three-fifths of the caldera with fluid circulation to depths of 1.5 to $2.5 \mathrm{~km}$ in a reservoir covering at least the western three-fifths of the caldera. A more areally restricted reservoir would require correspondingly deeper levels of circulation. Studies of saline deposits in Searles Lake which were derived from Long Valley indicate that the present-day hot-spring discharge has persisted for only 30,000 to 40,000 years. Estimates of reservoir volume and thickness required to leach observed quantities of $\mathrm{B}, \mathrm{Cl}, \mathrm{K}$, and $\mathrm{Li}$ are reasonable for a reservoir in the Bishop Tuff, indicating that a magmatic-fluid component providing chemical elements and heat to the hydrothermal system would not be required.

In contrast, evidence exists for extensive hydrothermal alteration about $0.3 \mathrm{~m}$.y. ago which appears to be related to the main magma chamber, rather than to the postcaldera eruptive rocks. Numerical simulations representing a period of 350,000 years, at which time steady-state conditions would be reached, indicate that to obtain present-day heat flow and reservoir temperatures above $200^{\circ} \mathrm{C}$ after this period, fluid circulation to depths of 4 to $5 \mathrm{~km}$ would be required. If downward extension of permeable channels to these depths in the basement rocks has not occurred, then the modeling results and the diverse indications of the age of hydrothermal activity suggest an alternative hypothesis that discharge from the hydrothermal system has been intermittent. It would, in fact, be reasonable to expect that significant periods of inactivity after $0.3 \mathrm{~m}$.y. ago resulted from climatic variations and self-sealing processes which are in evidence today. These possibilities, and the adequacy of the simplified hydrothermal model analyzed in this study, can be evaluated only by deeptest drilling in the western part of the caldera.

Under the eastern two-fifths of the caldera, reservoir temperatures measured in the $2.11 \mathrm{~km}$ test hole and the model simulations indicate that temperatures are sufficiently low to preclude the possibility of electrical-energy development east of Hot Creek. Temperature conditions close to those measured in the test hole were modeled by including a recharge flux of 110 $\mathrm{kg} / \mathrm{s}$ around the northeast rim and discharge at depth through the southeast rim. To determine if these flow conditions actually exist would also require further deep drilling. Although there presently exists little economic incentive to do more drilling in this area, selection of the east side of the caldera for possible reinjection of residual geothermal fluids could change this situation. Under normal conditions, the model results and geochemical analyses indicate that the cool reservoir water east of Hot Creek does not mix significantly with hot water discharging in Hot Creek gorge. However, should large-scale production of hot fluids occur in the future, the resultant westward migration of this cool water toward the production area would have to be considered. Of importance in this regard is the existence of any permeability barrier between the hot- and cold-water areas within the reservoir, which could have developed from chemical deposition along former fault-plane fluid conduits.

\section{REFERENCES GITED}

Anderson, L. A., and Johnson, G. R., 1973, The application of the self-potential method in the exploration for geothermal energy in Long Valley, California [abs]: Am. Geophys. Union EOS Trans., v. 54, no. 11, p. 1212.

_- 1976, Application of the self-potential method to geothermal exploration in Long Valley, California: Jour. Geophys. Research, v. 81, p. $1527-1532$.

Axelrod, D. I., 1962, A Pliocene Sequoiadendron forest from western Nevada: California Univ., Pub. Geol. Sci., v. 39, no. 3, p. 195268.

Axelrod, D. I., and Ting, W. S., 1961, Early Pleistocene floras from the Chagoopa surface, southern Sierra Nevada: California Univ., Pub. Geol. Sci., v. 39, no. 2, p. 119-194.

Bailey, R. A., 1974, Preliminary geologic map and cross sections of the Casa Diablo geothermal area, Long Valley caldera, Mono County, California: U.S. Geol. Survey open-file map, 2 p.

Bailey; R. A., Dalrymple, G. B.; and Lanphere, M. A., 1976, Volcanism, structure, and geochronology of Long Valley caldera, Mono County, California: Jour. Geophys. Research, v. 81, no. 5, p. $725-744$

Bailey, R. A., and Koeppen, R. P., 1977, Preliminary geologic map of Long Valley caldera, Mono County, California: U.S. Geol. Survey, open-file map, $2 \mathrm{p}$.

Bateman, P. C., 1965, Geology and tungsten mineralization of the Bishop district, California: U.S. Geol. Survey Prof. Paper 470, 208 p. 
Bateman, P. C., and Wahrhaftig, C., 1966, Geology of the Sierra Nevada in Geology of northern California: California Div. Mines and Geol. Bull. 190, p. 107-172.

Blake, A. H., and Matthes, F.E., 1938, The new Casa Diablo "geyser": Sierra Club Bull., v. 23, no. 2, p. 82-83.

Blaney, H. F., 1933, Rainfall penetration, Chap. 6, in Ventura County Investigation: California Dept. Public Works, Div. Water Resources Bull. 46, p. 82-90.

California Dept. Water Resources, 1967, Investigation of geothermal waters in the Long Valley area, Mono County; California Dept. Water Resources, Sacramento, California $114 \mathrm{p}$.

California Div. Oil and Gas, 1972, Geothermal map G-51, Casa Diablo, 1 in.: 2,000 ft.: Sacramento, Calif.

Chelikowsky, J. R., 1940, Tectonics of the rhyolite in the Mammoth embayment, California: Jour. Geology, v. 48, p. 421-435.

Christensen, M. N., 1966, Late Cenozoic crustal movements in the Sierra Nevada of California: Geol. Soc. America Bull., v. 77, p. 163-182.

Crowder, D. F., and Sheridan, M. F., 1972, Geologic map of the White Mountain Peak quadrangle, Mono County, California: U.S. Geol. Survey, Geol. Quad. Map GQ-1012.

Dalrymple, G. B., 1963, Potassium-argon dates of some Cenozoic volcanic rocks of the Sierra Nevada, California: Geol. Soc. America Bull., v. 74, p. 379-390.

1964, Cenozoic chronology of the Sierra Nevada, California: California Univ., Publ. in Geol. Sci., v. 47, 41 p.

Dalrymple, G. B., Cox, Allen, and Doell, R. R., 1965, Potassiumargon age and paleomagnetism of the Bishop Tuff, California; Geol. Soc. America Bull., v. 76, no. 6, p. 665-674.

Dorsey, N. E., 1968, Properties of ordinary water-substance: New York, Hafner Publishing Co. 673 p.

Elder, J. W., 1965, Physical processes in geothermal areas, in Lee, W. H. K., ed., Terrestrial Heat Flow: Am. Geophys. Union Monograph Series, v. 8, p. 211-239.

Ellis, A. J., 1970, Quantitative interpretation of chemical characteristics of hydrothermal systems: U.N. Symposium on Development and Utilization of Geothermal Resources, Pisa, Italy, p. 516-528.

Ellis, A. J., and Mahon, W. A. J., 1964, Natural hydrothermal systems and experimental hot water/rock interactions, Geochim. Cosmochim. Acta, v. 28, no. 8, p. 1323-1357.

Fournier, R. O., and Rowe, J. J., 1966, Estimation of underground temperatures from the silica content of water from hot springs and wet steam wells: Am. Jour. Sci., v. 264, p. 685-697.

Fournier, R. O., Sorey, M. L., Mariner, R. H., and Truesdell, A. H., 1976. Geochemical prediction of aquifer temperatures in the geothermal system at Long Valley, California: U.S. Geol. Survey open-file report 76-469, $34 \mathrm{p}$.

Fournier, R. O., and Truesdell, A. H., 1973, An empirical Na-K-Ca geothermometer for natural waters: Geochim. et Cosomochim. Acta, v. 37, p. 1255-1275.

Friedman, Irving, and Smith, G. I., 1970, Deuterium content of snow cores from Sierra Nevada area: Science, v. 169, p. 467-470. 1972, Deuterium content of snow as an index to winter climate in the Sierra Nevada area: Science, v. 176, p. 790-793.

Gilbert, C. M., 1938, Welded tuff in eastern California: Geol. Soc. America Bull., v. 49, no. 12, pt. 1, p. 1829-1862.

— 1941, Late Tertiary geology southeast of Mono Lake, California: Geol. Soc. America Bull., v. 52, p. 781-816.

Hill, D. P., 1976, Structure of Long Valley caldera, California, from a seismic refraction experiment: Jour. Geophys. Research, v. 81 , no. 5 , p. $745-753$.

Hill, D. P., McHugh, S. L., and Pakiser, L. C., 1973, Structure of the Long Valley caldera from detailed seismic-refraction measurements [abs]: Amer. Geophys. Union EOS Trans., v. 54; no.
11, p. 1211.

Hoover, D. B., Frischknecht, F. C., and Tippens, C. L., 1973, Audiomagnetotelluric sounding as a reconnaissance exploration technique in Long Valley, California [abs]: Am. Geophys. Union EOS Trans., v. 54 , no. 11, p. 1212.

1976, Audiomagnetotelluric sounding as a reconnaissance exploration technique in Long Valley, California: Jour. Geophys. Research, v. 81 , no. 5, p. 801-809.

Houk, I. E., 1951, Irrigation engineering, v. 1-Agricultural and hydrological phases: New York, John Wiley and Sons, 545 p.

Huber, N. K., and Rinehart, C. D., 1965, Geologic map of the Devil's Postpile quadrangle, Sierra Nevada, California: U.S. Geol. Survey Geol. Quad Map GQ-437, scale 1:62,500.

Iyer, H. M., and Hitchcock, T., 1976, Seismic noise survey in Long Valley, California: Jour. Geophys. Research, v. 81, no. 5, p. 821840.

Jackson, D. B., Stanley, W. D., and Zohdy, A. A. R., 1973, Direct current and electromagnetic soundings in Long Valley, California [abs]: Am. Geophys. Union EOS Trans., v. 54, no. 11, p. 1212.

Jacob, C. E., 1950, Flow of ground-water, in Rouse, Hunter, ed., Engineering Hydraulics: New York, John Wiley and Sons, p. 321386.

Kane, M. F., and Mabey, D. R., 1973, Gravity and magnetic anomalies in Long Valley, California [abs]: Am. Geophys. Union EOS Trans., v. 54 , no. 11 , p. 1211.

Kane, M. F., Mabey, D. R., and Brace, R. L., 1976a, A gravity and magnetic investigation of the Long Valley caldera, Mono County, California [abs]: Am. Geophys. Union EOS Trans., v. 57, no. 2 , p. $100-101$.

$1976 \mathrm{~b}, \mathrm{~A}$ gravity and magnetic investigation of the Long Valley caldera, Mono County, California: Jour. Geophys. Research, v. 81 , no. 5 , p. $754-762$.

Kaysing, W. D., ed., 1970, Thermal springs of the western United States: Santa Barbara, Calif,, Paradise Publishers, 36 p.

Keller, G. V., 1960, Physical properties of tuffs of the Oak Spring Formation, Nevada in Geological Survey research 1960: U.S. Geol. Survey Prof. Paper 400-B, p. 396-400.

King, G. C. P., 1971, The siting of strainmeters for teleseismic and tidal studies: Royal Soc. New Zealand Bull. 9, p. 239-247.

Lachenbruch, A. H., 1968, Preliminary geothermal model of the Sierra Nevada: Jour. Geophys. Research, v. 73, p. 6977-6989.

1970 , Crustal temperature and heat production: Implications of the linear heat-flow relation: Jour. Geophys. Research, v. 75, p. 3291-3300.

Lachenbruch, A. H., Lewis, R. E., and Sass., J. J., 1973, Prospecting for heat in Long Valley [abs]: Am. Geophys. Union EOS Trans., v. 54 , no. 11 , p. 1211.

Lachenbruch, A. H., Sass, J. H., Munroe, R. J., and Moses, T. H., Jr., 1976, Geothermal setting and simple heat-conduction models for the Long Valley caldera: Jour. Geophys. Research, v. 81, no. 5, p. 769-784.

Lachenbruch, A. H., Sorey, M. L., Lewis, R. E., and Sass, J. H., 1976, The near-surface hydrothermal regime of Long Valley caldera: Jour. Geophys. Research, v. 81, no. 5, p. 763-768.

Lee, C. H., 1912, An intensive study of the water resources of a part of Owens Valley, California: U.S. Geol. Survey Water Supply Paper 294, $135 \mathrm{p}$.

Lee, W. T., 1906, Geology and water resources of Owens Valley, California: U.S. Geol. Survey Water Supply Paper 181, 28 p.

Lewis, R. E., 1974, Data on wells, springs and thermal springs in Long Valley, Mono County, California: U.S. Geol. Survey openfile report, $52 \mathrm{p}$

1975, Data from a 1,000-foot (305-meter) core hole in the Long Valley caldera, Mono County, California: U.S. Geol. Survey open-file report, $16 \mathrm{p}$. 
Lindgren, W., 1911, The Tertiary gravels of the Sierra Nevada of California: U.S. Geol. Survey Prof. Paper 73, 226 p.

McDonald, C. C., and Hughes, G. H., 1968, Studies of consumptive use of water by phreatophytes and hydrophytes near Yuma, Arizona: U.S. Geol. Survey Prof. Paper 486-F, 24 p.

McKenzie, W. F., and Truesdell, A. H., 1977, Geothermal reservoir temperatures estimated from the oxygen-isotope compositions of dissolved sulfate in water from hot springs and shallow drill holes, in Proc. Int. Atomic Energy Agency Advisory Group on the Application of Nuclear Techniques to Geothermal Studies, Pisa, Italy: Geothermics, Special Issue (in press).

McNitt, J. R., 1963, Exploration and development of geothermal power in California: California Div. Mines and Geol. Spec. Rept. $75,45 \mathrm{p}$.

Mariner, R. H., and Willey, L. M., 1976, Geochemistry of thermal waters in Long Valley, Mono County, California: Jour. Geophys. Research, v. 81 , no. 5, p. $792-800$.

Matthes, F. E., 1930, Geologic history of the Yosemite Valley: U.S. Geol. Survey Prof. Paper 160, 137 p.

1933, Geography and geology of the Sierra Nevada, in XVI Int. Geol. Cong. Guidebook: Washington, D.C., U.S. Govt. Printing Office, v. 16, part c-1, p. 26-40.

-1939 , History of faulting movements at the east front of the Sierra Nevada, as indicated by dislocated moraines [abs]: Geol. Soc. America Bull., v. 50, p. 1955.

1947, A geologist's view, in Peattie, Roderick, ed., The Sierra Nevada: New York, Vanguard Press, p. 166-214.

Mayo, E. B., 1934, Geology and mineral resources of Laurel and Convict basins, southwestern Mono County, California: California Jour. Mínes and Geol., v. 30, no. 1, p. 79-88.

Mercer, J. W., Pinder, G. F., and Donaldson, I. G., 1975, A Galerkin finite-element analysis of the hydrothermal system at Wairakei, New Zealand: Jour. Geophys. Reserach, v. 80, no. 17, p. 2608 2621.

Muffler, L. J. P., and Williams, D. L., 1976, Geothermal investigations of the U.S. Geological Survey in Long Valley, California, 1972-1973: Jour. Geophys. Research, v. 81, no. 5, p. 721-724.

Narasimhan, T. N., and Witherspoon, P. A., 1976, An integrated finite difference method for analyzing fluid flowing porous media: Water Resources Research, v. 12, no. 1, p. 57-64.

Nathenson, M., nad Muffler, L. J. P. , 1975, Geothermal resources in hydrothermal convection systems and conduction-dominated areas; in White, D. E., and Williams, D. E., eds., Assessment of geothermal resources of the United States, 1975: U.S. Geol. Survey Cir. 726, p. 104-121.

Noble, D. C., Korringa, M. K., Hedge, C. E., and Riddle, G. O., 1972, Highly differentiated subalkaline rhyolite from Glass Mountain, Mono County, California: Geol. Soc. America Bull., v. 83, p. 1179-1184.

Pakiser, L. C., 1961, Gravity, volcanism, and crustal deformation in Long Valley, California, in Geological Survey research 1961: U.S. Geol. Survey Prof. Paper 424-B, p. 250-253.

-1968, Seismic evidence for the thickness of Cenozoic deposits in Mono Basin, California: Geol. Soc. America Bull., v. 79, p. $1833-1838$.

Pakiser, L. C., Kane, M. F., and Jackson, W. H., 1964, Structural geology and volcanism of Owens Valley region, California, a geophysical study: U.S. Geol. Survey Prof. Paper 438, 68 p.

Pakiser, L. C., Press, F., and Kane, M. F., 1960, Geophysical investigation of Mono Basin, California: Geol. Soc. America Bull., v. 71, p. $415-448$.

Piper, A. M., Gale, H. S., Thomas, H. E., and Robinson, T. W., 1939, Geology and ground-water hydrology of the Mokelumne area, California: U.S. Geol. Survey Water-Supply Paper 780, 230 p.

Putman, W. C., 1940, Quaternary geology of the June Lake district,
California [abs]: Geol. Soc. America Bull., v. 51, no. 12, pt. 2, p. 1939-1940.

1949, Quaternary geology of the June Lake district, California: Geol. Soc. America Bull., v. 60, p. 1281-1302.

-1960 , Origin of Rock Creek and Owens River gorges, Mono County California: California Univ., Pub. Geol. Sci., v. 34, p. 221-280.

1962, Late Cenozoic geology of McGee Mountain, Mono County, California: California Univ., Pub. Geol. Soc., v. 40, no. 3, p. $181-218$.

Rantz, S. E., 1972, Mean annual precipitation in the California region: U.S. Geol. Survey Basic Data Compilation (2 maps at 1:1,000,000), Menlo Park, Calif.

Ratté, J. C., and Steven, T. A., 1967, Ash flows and related volcanic rocks associated with the Creede caldera, San Juan Mountains, Colorado: U.S. Geol. Survey Prof. Paper 524-H, 58 p.

Rinehart, C. D., and Ross, D. C., 1957, Geology of the Casa Diablo Mountain quadrangle, California: U.S. Geol. Survey Geol. Quad. Map GQ-99.

-1964, Geology and mineral deposits of the Mount Morrison quadrangle, Sierra Nevada, California, with a section on A gravity study of Long Valley by L. C. Pakiser: U.S. Geol. Survey Prof. Paper 385, $106 \mathrm{p}$.

Roy, R. F., Blackwell, D. D., and Birch, Francis, 1968, Heat generation of plutonic rocks and continental heat-flow provinces: Earth and Planetary Sci. Letters, v. 5, p. 1-12.

Russell, I. C., 1889, Quaternary history of Mono Valley, California: U.S. Geol. Survey 8th Ann. Rept., p. 261-394.

Sass, J. H., Lachenbruch, A. H., and Munroe, R. J., 1974, Thermal data from heat-flow test wells near Long Valley, California: U.S. Geol. Survey open-file report, $43 \mathrm{p}$.

Sheridan, M. F., 1965, The mineralogy and petrology of the Bishop Tuff: Ph.D. thesis, Stanford Univ., Stanford, Calif,, 165 p. 1968, Double cooling-unit nature of the Bishop Tuff in Owens Gorge, California [abs]: Geol. Soc. America Spec. Paper 115, p. 351.

1971, Guidebook to the Quaternary geology of the east-central Sierra Nevada: Guidebook, XVI Field Conf., Rocky Mountain Section, Friends of the Pleistocene, Oct. 9-10, 1971.

Smith, G. I., 1976, Origin of lithium and other components in the Searles Lake evaporites, California, in Vine, J. D., ed., Lithium resources and requirements by the year 2000: U.S. Geol. Survey Prof. Paper 1005, p. 92-103.

Sorey, M. L., 1975a, Numerical molding of liquid geothermal systems: U.S. Geol. Survey open-file report 75-613, 66 p.

-M. L., 1975b, Potential effects of geothermal development on springs at the Hot Creek Fish Hatchery in Long Valley, Mono County, California: U.S. Geol. Survey open-file report 75-637, 10 p.

Sorey, M. L., and Lewis, R. E., 1976, Convective heat flow from hot springs in the Long Valley caldera, Mono County, California: Jour. Geophys. Research, v. 81, no. 5, p. 785-791.

Spreen, W. C., 1947, A determination of the effect of topography upon precipitation: Am. Geophys. Union Trans., v. 28, no. 2, p. 285290.

Stanley, W. D., Jackson, D. B., and Zohdy, A. A. R., 1973, A totalfield resistivity map of Long Valley, California [abs]: Am. Geophys. Union EOS Trans., v. 54, no. 11, p. 1212.

- 1976 , Deep electrical investigations in the Long Valley geothermal area, California: Jour. Geophys. Research, v. 81, no. 5, p. $810-820$.

Stearns, N. D., Stearns, H. T., and Warning, G. A., 1937, Thermal springs in the United States: U.S. Geol. Survey Water-Supply Paper 679-B, p. 59-206.

Steeples, D. W., and Iyer, H. M., 1976, Low velocity zone under Long 
Valley as determined from teleseismic events: Jour. Geophys. Research, v. 81 , no. 5, p. 849-860.

Steeples, D. W., and Pitt, A. M., 1973, Microearthquakes in and near Long Valley, California [abs]: Am. Geophys. Union EOS Trans., v. 54 , no. 11, p. 1213 .

_ 1976, Microearthquakes in and near Long Valley, California: Jour. Geophys. Research, v. 81, no. 5, p. 841-847.

Steiner, A., 1955, Hydrothermal rock alteration, in Geothermal steam for power: New Zealand Dept. Scientific and Industrial Research, Bulletin 117, p. 21-26.

Taylor, H. P., 1976, Water/rock interactions and the origin of the $\mathrm{H}_{2} \mathrm{O}$ in granitic batholiths, Thirtieth William Smith Lecture: California Inst. Technology, Div. Geol. and Planetary Sci. Contr. no. $2790,105 \mathrm{p}$

Waring, G. A., 1915, Springs of California: U.S. Geol. Survey Water-Supply Paper 338, $310 \mathrm{p}$.

-1965 , Thermal springs of the United States and other countries of the world, a summary: U.S. Geol. Survey Prof. Paper 492, $383 \mathrm{p}$.

White, D. E., 1965, Geothermal energy: U.S. Geol. Survey Circ. 519, $17 \mathrm{p}$.

1968, Hydrology, activity, and heat flow of the Steamboat Springs thermal system, Washoe, County, Nevada: U.S. Geol.
Survey Prof. Paper, 458-C, 104 p.

White, D. E., Muffler, L. J. P., and Truesdell, A. H., 1971, Vapordominated hydrothermal systems compared with hot-water systems: Econ. Geology, v. 66 , no. 1, p. 75-97.

White, W. N., 1932, A method of estimation of ground-water supplies based on discharge by plants and evaporation from soil, results of investigation in Escalante Valley, Utah: U.S. Geol. Survey Water-Supply Paper 659-A, 105 p.

Whiting, H. A., 1888, Mono County: California Mining Bur., 8th Ann. Rept., p. 352-401.

Willey, L. M., O'Neil, J. R., and Rapp, J. B., 1974, Chemistry of thermal waters in Long Valley, Mono County, California: U.S. Geol. Survey open-file report, $19 \mathrm{p}$.

Williams, D. L., 1976, Implications of a magnetic model of the Long Valley caldera, California: U.S. Geol. Survey open-file report 76-439, 7 p.

Winograd, I. J., Thordarson, William, and Young, R. A., 1971, Hydrology of the Nevada Test Site and vicinity: U.S. Geol. Survey open-file report, $429 \mathrm{p}$.

Wood, S. H., 1975, Mono and Inyo Crater eruptions, eastern California-Radiocarbon dating and trace element correlations of late Pleistocene tephra [abs]: Geol. Soc. America Abs. with Programs, Cordilleran Section, v. 7, no. 3, p. 389. 

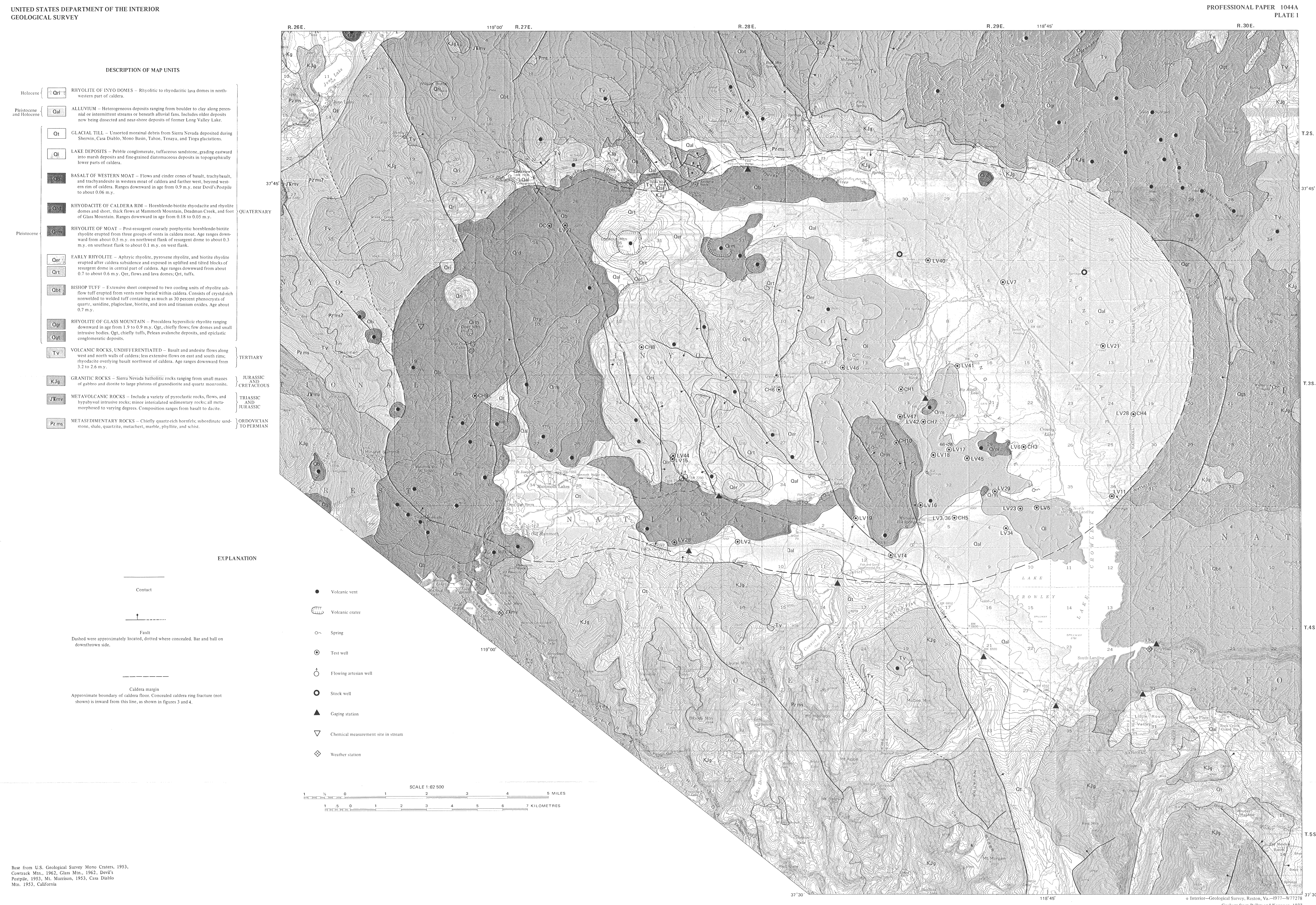